\title{
A Demonstration of Citizenship: \\ The Response of Canadian Suffragists to the Emergence of Film
}

by

\section{Laura Carlson}

A thesis submitted to the Faculty of Graduate and Postdoctoral Affairs in partial fulfillment of the requirements for the degree of

Master of Arts

School of Journalism and Communication

Carleton University

Ottawa, Ontario

May 2012

C) 2012 Laura Carlson 
Library and Archives

Canada

Published Heritage

Branch

395 Wellington Street

Ottawa ON K1A ON4

Canada
Bibliothèque et

Archives Canada

Direction du

Patrimoine de l'édition

395 , rue Wellington

Ottawa ON K1A ON4

Canada
Your file Votre référence

ISBN: 978-0-494-91557-8

Our file Notre référence

ISBN: $978-0-494-91557-8$
NOTICE:

The author has granted a nonexclusive license allowing Library and Archives Canada to reproduce, publish, archive, preserve, conserve, communicate to the public by telecommunication or on the Internet, loan, distrbute and sell theses worldwide, for commercial or noncommercial purposes, in microform, paper, electronic and/or any other formats.

The author retains copyright ownership and moral rights in this thesis. Neither the thesis nor substantial extracts from it may be printed or otherwise reproduced without the author's permission.
AVIS:

L'auteur a accordé une licence non exclusive permettant à la Bibliothèque et Archives Canada de reproduire, publier, archiver, sauvegarder, conserver, transmettre au public par télécommunication ou par l'Internet, prêter, distribuer et vendre des thèses partout dans le monde, à des fins commerciales ou autres, sur support microforme, papier, électronique et/ou autres formats.

L'auteur conserve la propriété du droit d'auteur et des droits moraux qui protege cette thèse. $\mathrm{Ni}$ la thèse ni des extraits substantiels de celle-ci ne doivent être imprimés ou autrement reproduits sans son autorisation.
In compliance with the Canadian Privacy Act some supporting forms may have been removed from this thesis.

While these forms may be included in the document page count, their removal does not represent any loss of content from the thesis.
Conformément à la loi canadienne sur la protection de la vie privée, quelques formulaires secondaires ont été enlevés de cette thèse.

Bien que ces formulaires aient inclus dans la pagination, il n'y aura aucun contenu manquant. 


\begin{abstract}
This thesis takes a historical approach to examine the Canadian suffrage movement in conjunction with film. Based on archival research there are two areas that I explore. Firstly, I examine suffragists' response to the increasingly popular activity of filmgoing. The National Council of Women of Canada (NCWC) condemned the sites of exhibition and the content of moving pictures, championed film's educational potential, and took steps to regulate what was screened in Canada. Secondly, I explore the Canadian exhibition of American suffrage films. Although suffragists in the United States produced six films, there are no records of Canadian suffragists making moving pictures, although American suffrage films were shown in Montreal (1912 and 1914) and Toronto (1914). Consistent with Canadian suffragists' First World War publicity approach, the screening of the American film Your Girl and Mine raised money for the war effort, a technique that suffragists believed demonstrated women's right to citizenship.
\end{abstract}




\section{Acknowledgements}

There are many people I would like to thank for ensuring the completion of this thesis, especially my committee. Firstly, my supervisor Eileen Saunders challenged me intellectually to ensure that my work was up to her academic standards, offering invaluable theoretical and practical insight. Despite Eileen's multitude of other responsibilities, she was willing to read multiple drafts of chapters and always returning my work in a timely manner, especially in the last few weeks of the writing process. The enthusiasm of my second reader Ira Wagman helped me to focus in on my area of study, think about what was obtainable for me to complete with a master's level thesis, and helped prepare me for my oral defence. My external committee member Rena Bivens asked great questions at the defence, and Mary Francoli served as an excellent chair.

There are many other academics that helped me with this project at various stages. Amy Shore's continued excitement about my work was a constant source of encouragement. Not only was Amy Shore the first researcher to bring a Canadian screening of a suffrage film to my attention, but her willingness to share her book manuscript with me was invaluable, as this project certainly wouldn't have been as thorough and complete without the inclusion of her fascinating research. Shelley Stamp, Charles Tepperman, Paul Moore, Anne-Marie Kinahan, and Kirsten Kozolanka, were also willing to discuss my research and offered me a lot of advice and insight, especially during the planning phases of my proposed project.

The friendships I developed in graduate school have been a constant source of support over the past two years. While residing in Winnipeg, Avery edited drafts and the final copy of this thesis, offering positive comments and always reminding me that grad 
school is actually a pretty nice place to be in comparison to the "real world." Dan, the second half of the Communications Graduate Caucus (CGC) "social couch", was a committed library and Bridgehead study buddy, sharing in my craziness levels in the final phases of this project. It was a pleasure to get to know fellow 1101 TAs, members of the CGC, professors, as well as other students in my program - Gina, Martin, Chelsea, and Gen among others.

Travel grants from the Department of Graduate Studies and Postdoctoral Affairs allowed me to complete research in Montreal, Toronto and Waterloo. The staff at Library and Archives Canada, Wilfrid Laurier University Archives, City of Montreal Archives, and the Thomas Fisher Rare Book Library were extremely helpful. Lauren, Andrea, Linda, Mike, and Rebecca ensured I had places to stay on the various legs of my "research vacation", and were great company in the evenings when the archives were closed. Colleen from the Communication office helped to ensure all administrative tasks were completed.

Finally, my place of employment throughout this thesis writing process, the ByTowne Cinema, offered me hours of escape each week, in the company of great people. Not only did I discover that my dream job of getting paid to watch movies actually does exist, but engaging discussions with fellow cinephiles sustained my love for film and reminded me that when it's my time to leave academia there awaits a world of passionate and creative people. 


\section{Table of Contents}

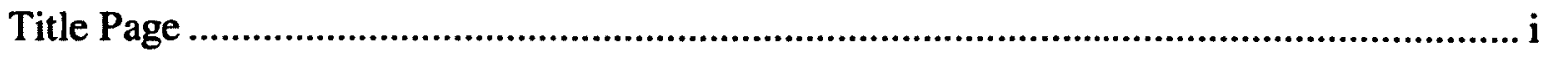

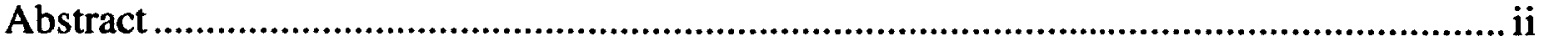

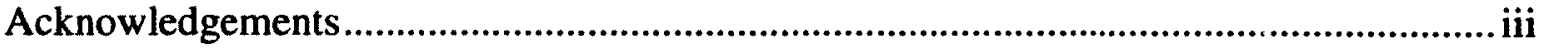

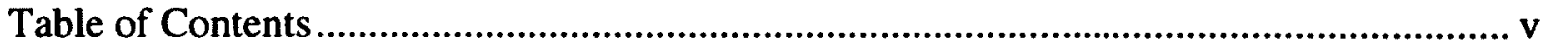

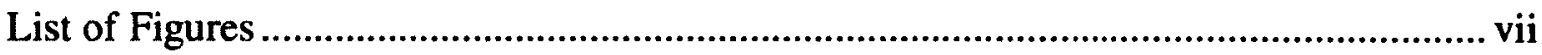

Introduction: An unexplored connection: The study of suffragists and early film . viii

Chapter One: 'First wave' suffragists................................................................... 1

1.1 - A time of social and moral reform in North America ......................................... 3

1.2 - The rise of maternal feminists: Women as civic housekeepers ............................ 5

1. 3 - Canadian suffrage organizations .................................................................. 11

1.4 - Suffrage unity: The National Council of Women of Canada (NCWC)................ 13

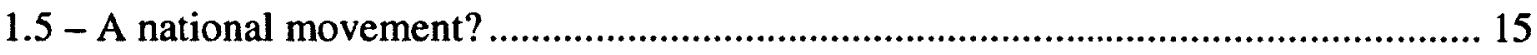

1.6 - Suffragists in the city: Urban women at the turn of the century ........................... 17

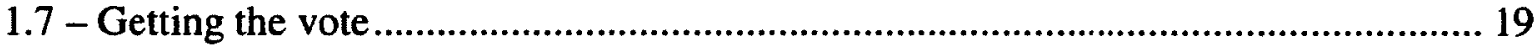

1.8 - Suffragists during wartime .................................................................. 23

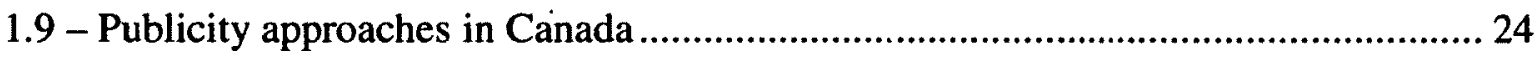

Chapter Two: Two distinct responses: Regulating and utilizing film ................... 28

2.1 - The emergence of film in North American culture............................................ 28

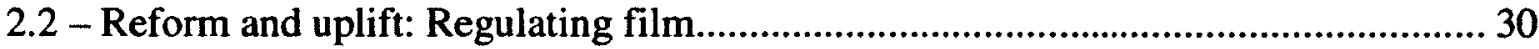

2.3 - Alternative media: The potential of film for advocacy...................................... 35

2.4 - American suffrage films: A 'historical footnote' of great importance .................. 44

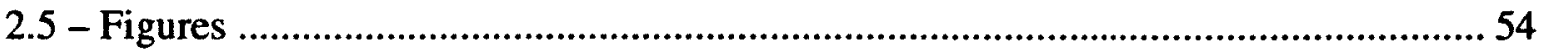

Chapter Three: A nation of exhibition: The lack of Canadian suffrage productions

3.1 - The absence of early Canadian filmmaking.................................................. 58

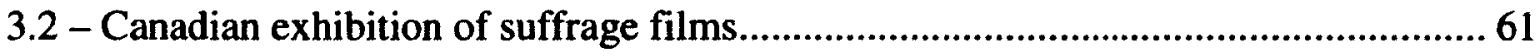

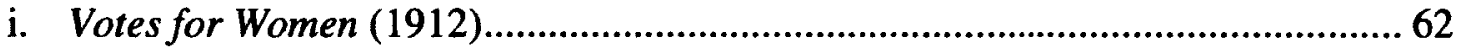

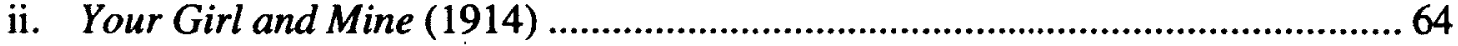




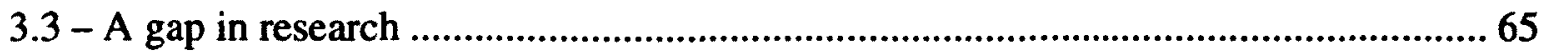

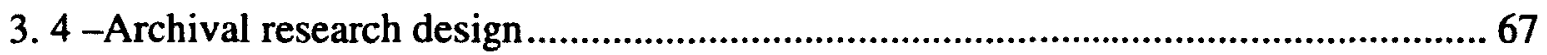

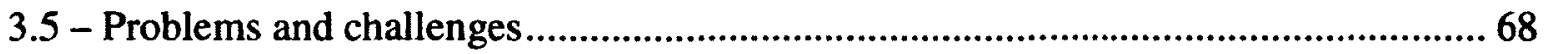

3.6 - Description of the archives consulted ................................................................... 70

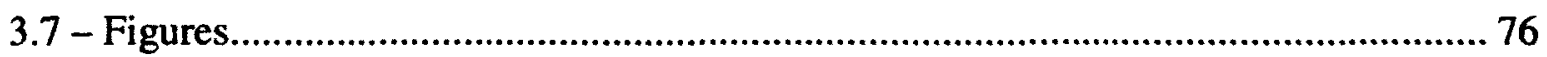

Chapter Four: The Canadian response: How suffragists addressed film ................. 78

4.1 - The NCWC: The context of discussion ................................................................ 78

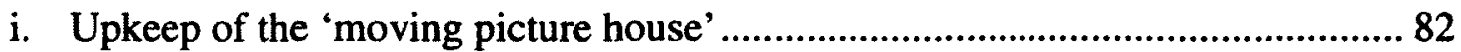

i. Censorship: Women as censors........................................................................ 93

ii. Using film for education .................................................................................. 97

4.4 - Cinematic advocacy: Alternative media raising funds for the war effort.............. 101

i. Screening: Votes for Women - Montreal, June, 1912 ..................................... 105

ii. Screenings: Your Girl and Mine - Montreal and Toronto, 1914 .................... 108

4.5 - Figures........................................................................................................... 115

Conclusion: A demonstration of citizenship: Regulation and suffrage advocacy .. 118

5.1 - The suffragist response to film: A focus on regulation....................................... 119

5.2 - The 'success' of suffrage film screenings.............................................................. 122

5.3 - Suggestion for further research ........................................................................... 126

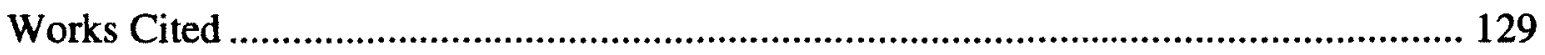

Primary sources.................................................................................................. 129

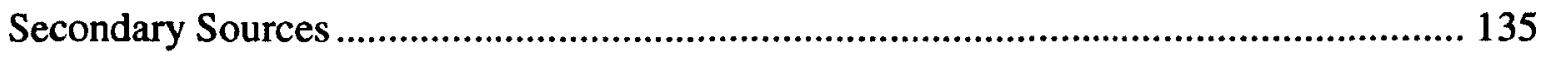




\section{List of Figures}

Figure 1: "Votes for Women". $\quad 54$

Figure 2: "Your Girl and Mine."

Figure 3: "Announcement: Special Attractions Department." 56

$\begin{array}{ll}\text { Figure 4: "Suffragette Pageant and Tableau." } & 76\end{array}$

Figure 5: "Suffragette Reels: April 27th." 77

Figure 6: Mrs. Inez Milholland Boissevain. 115

Figure 7: A still featuring a group of prominent suffragists in Votes for Women 116

Figure 8: A still from Your Girl and Mine with Dr. Anna Howard Shaw in centre 117

vii 


\section{Introduction}

\section{An unexplored connection: The study of suffragists and early film}

The suffrage movement in Canada has been documented by historians (see, for example: Bacchi, 1983; Cleverdon, 1974; Kealey, 1979), yet little research has looked at this movement in conjunction with the role of media. During the "first wave" of the women's movement (roughly 1890-1920) there were concrete advances in women's rights, and the 1910 s were a particularly active decade. The federal government extended suffrage to women in $1918^{\prime}$, and with the exception of Prince Edward Island and Quebec $^{2}$, women in all provinces received the provincial vote during the 1910 s. The early part of the twentieth century was also an important time for film. Following the debut of the kinescope in Canada in 1884, throughout the 1910s film theatres were opening in urban centres across the country and filmgoing became an activity that was incorporated into the everyday lives of North Americans (Moore, 2008).

American film scholars Kay Sloan $(1981 ; 1988)$, Shelley Stamp $(1998 ; 2000)$ and Amy Shore (2010; forthcoming 2013) have shed light on the link between early film and the suffrage movement in the United States, as American suffragists used film as a means to promote their cause. Suffrage groups in the United States screened movies they produced (often in conjunction with a studio) as part of their recruitment and publicity strategy (Shore, 2010). Despite similarities between the American and Canadian suffrage

${ }^{1}$ Some women were granted federal voting rights in 1917 as part of the Military Voters Act. At the provincial level suffrage was achieved for most Canadian women throughout the 1910s. See chapter one for more detail.

${ }^{2}$ Women in Newfoundland did not have the vote at this point either; however, the province was not yet part of Canada. 
movements, no scholars have researched film in the context of the Canadian suffrage movement.

This thesis employs archival research to explore the conditions surrounding the Canadian exhibition of American suffrage films, as well as the reception of film by suffragists. Chapter one situates the first wave of the women's movement in the era of North American social and moral reform. I will focus on how suffragists' commitments to "maternal feminism" and "civic housekeeping" influenced perceptions about the medium, and their solutions to address them. This will be central when discussing the results of my findings in chapter four. In chapter two I turn to a discussion on the emergence of film in North America, and highlight concerns that arose because of the perceived influence of the new medium. While early film was popular for its entertainment value, the medium also had a potential for advocacy, and I demonstrate how the films produced by American suffragists' were a form of alternative media. This chapter also surveys the existing literature on American suffrage films. Chapter three offers historical information about the Canadian film industry in the 1910s, and outlines what is known about the Canadian screenings of American suffrage films.

The lack of scholarship that directly addresses suffrage films in a Canadian context presents a need for further research, and at the end of chapter three I outline the methodology of my archival study. I then turn to an analysis of this information to better comprehend how suffragists were responding to the emerging medium of film in the context of the social reform movement of the 1910s. I aim to understand if Canadian suffragists were using film for advocacy purposes like those in the United States. An exploration of the suffrage movement in conjunction with the emergence of film provides 
valuable insight not only into the history of alternative media, but also about the ways in which suffragists both reacted to, and utilized, the new medium of film.

While this study offers an overview of how suffragists were responding to the medium of film, there are limitations to it. As little is known about the topic, I chose archival research to find out as much information as possible about the suffragists' response. However, this approach is not without problems. By staying within the official archives I did not look at peripheral sources for raw data - newspapers, fire code regulations, building permits, government information, bylaws, census demographics, etc. to name just a few - and as a result this research can only say so much. Relying exclusively on the archives of activist organizations with particular political goals results in conclusions that are biased from the perspective of those I researched. For a preliminary research project I chose to paint a broad picture of how suffragists were responding to film, as opposed to focusing in on a particular case study and offering a highly detailed account of how a very small group of suffragists were reacting to films' presence in one urban centre.

Before I turn to chapter one, a few notes about the terminology used throughout this thesis. There is some debate about the use of the word feminism when exploring the history of the women's movement, especially the first wave. For Bacchi (1983), because social and moral reforms were central in the suffrage movement the cause "lost all identification with the feminist call to enter and compete in the male domain" (p. 147). Shore (2010) on the other hand specifically categorizes those who were making suffrage films in the United States as "feminists" and argues that their work "deserves to be studied as early feminist films" (p. 324). Although certainly a worthwhile debate to 
consider, for the purpose of this study I choose not to employ the term feminist when referring to those who were advocating for women's voting rights.

I do refer to "maternal feminism" in the context of theory relating to the suffrage movement (section 1.2). I use this as a descriptive word to discuss the women who believed that their motherly roles qualified them as model citizens. I am less concerned with the terms theorists have developed to analyze these women than the rhetoric that these women employed to discuss film. I seek to look at a particular movement and understand how those who were part of it used and talked about the medium of film.

Suffragist is the term I employ to describe the associations and women researched in this study. I feel this is the most reflective word to describe the women who belonged to the various associations whose archives were consulted for this project. This is not without problems, as the National Council of Women of Canada (NCWC), whose archives I rely on quite heavily for this project, was not formed as a suffrage organization. The NCWC did endorse suffragism in 1910, and became the largest Canadian women's group who supported the cause (Cleverdon, 1974). As films produced by American suffragists are central in this study, and all associations whose archives were consulted supported suffragism during the 1910s, I felt that it was the most appropriate term. As most of the individuals who were part of suffrage societies were Anglo-Saxon, Protestant, middle-class, and reformers (Bacchi, 1979), the NCWC membership was representative of the general suffragist profile. This is not to say that suffragism was the central or defining feature for all of the women associations explored in this study, but it was a common thread that tied them together. 


\section{Chapter One \\ 'First wave' suffragists}

The "first wave" of the women's movement is thought to extend roughly from the 1880 s to the $1920 \mathrm{~s}^{3}$. Kealey (1979) identifies this period as particularly active in the growth of women's organizations across the nation, many of which advocated for suffrage. The first generation of suffragists came about in 1880 , when there were changes in women's employment. By then Canada's capitalist industrial system was in place, and between 1880 and 1920 intensive urbanization occurred across the country. This resulted in women coming together to deal with the social outcomes of city life. While the enfranchisement of women was key during the first wave of the women's movement, other issues such as social reform, labour laws and temperance were important for many activists during this period (Kealey, 1979; Bacchi, 1983). As women received the federal vote in 1918, and most provinces achieved suffrage during the 1910s, many women's associations that had been active during this period disbanded or concentrated on other issues by the 1920s. 1880-1920 was a time of activism and concrete advances in women's rights. This was also a period where women publicly articulated their stances on the various social issues of the day.

A review of the literature on the first wave of the Canadian women's movement reveals a number of academic works focusing on suffrage. Published in 1950, Catherine L. Cleverdon's The woman suffrage movement in Canada: The start of liberation is the foundational book on the subject. It was the first academic study on the suffrage movement in Canada, and when it was re-published in 1974 it still held the status as the

${ }^{3}$ Other authors highlight similar time periods: $1877-1918$ (Bacchi, 1983); 1877-1914 (Roberts, 1979); 1885-1925 (Valverde, 1991). 
most comprehensive source. As Ramsay Cook writes in the introduction to the 1974 edition, Cleverdon's analysis "remains the authoritative, indeed the only complete account of the suffragist struggle in Canada" (vii). Nearly forty years later Cook's observation is still valid. While there have been various scholarly works published since the 1970s on the Canadian suffrage movement (Bacchi, 1983; Fiamengo, 2006; Iacovetta \& Valverde, 1992; Thieme, 2006; Valverde, 1992), Cleverdon's work remains the most descriptive account. It sketches out how suffrage organizations across the country operated and the types of activities in which they participated. Her detailed study draws from the official archives of nearly every suffrage organization in Canada, and contains interviews with well over fifty individuals who were part of, or had some connection to, the first wave of the women's movement.

Although Cleverdon's book is perhaps the most complete account of the official movement, later work takes on a more critical tone and highlights how race and class interacted with gender to shape the early women's movement (Bacchi, 1983; Fiamengo, 2006; Iacovetta \& Valverde, 1992). In their 1992 collection of essays, Gender conflicts: New essays in women's history, Franca lacovetta and Mariana Valverde write that the experiences of middle-class Canadian women who dominated the women's movement need to be "analysed rather than celebrated" (p. xvii). Critics have challenged previous celebratory understandings of suffragists and their accomplishments, demonstrating how classist and racist assumptions impacted the movement (Valverde, 1992; Fiamengo, 2006). 


\section{1 - A time of social and moral reform in North America}

During the first wave of the women's movement, a general "reform" was taking place in North American culture. The belief was that through the organization of "likeminded citizens" nations could be "reformed to ensure progress and continuance of a moral, civilized, virtuous society" (Errington, 1988, p. 65). This movement was conservative in nature, and focused on issues such as strengthening families, protecting children, preventing physical illnesses (such as venereal disease), and preserving the Anglo-Saxon race (Bacchi, 1983).

In the early twentieth century scientific, specifically evolutionary, theories impacted reformist approaches. At this time two dominant positions emerged about how to best preserve the Anglo-Saxon race and prevent "race suicide": environmentalism and eugenics (Bacchi, 1983, p. 106). While environmentalism stressed that the environment caused physical and mental changes in the population that would be passed to the next generation, eugenics stressed the importance of nature and genetics, downplaying the impact of nurture. The reform movement supported both schools of thought, and although there was a eugenic undertone in the values of the reformist movement, environmentalists worked to improve the general standard of living (Bacchi, 1983).

It is not surprising that in general suffragists tended to support environmentalism, as this view gave women a more active role in the future of the AngloSaxon race (Bacchi, 1983). As Bacchi (1983) writes, "Environmentalism provided much greater scope for women to contribute actively to the creation of the new race, while eugenics reduced the maternal function to a mere biological capacity" (p. 108-109). Environmentalism was used as justification for women's higher education and their 
contribution to the reform movement. Key issues for reformers were immigration, crime, poverty, temperance, religious instruction, better housing, facilities for single women, health care, childhood programs, and workplace environments (Errington, 1988). Women's involvement in such activities "compelled them to press for direct involvement in the political life of the nation" (Errington, 1998, p. 65).

The reform movement was not specific to Canada, but was also prominent in the northeastern United States and urban Britain, which experienced similar "economic and cultural" developments (Valverde, 1991). Although Canadians tended to see their country as "less corrupt and healthier" than America, Canadian reformers were still highly influenced by how the movements were being carried out in these two places. For instance, temperance was central in the United States and British reform movements, and it came to be a key issue in Canada as well (Valverde, 1991). On the whole, the "welleducated urban English Canadians who led these movements were definitely learning from English and, increasingly, American sources" (Valverde, 1991, p. 16).

A specific part of reformist work was what Valverde (1991) refers to as the "social purity" movement in Canada. Valverde argues that it is critical to understanding moral reform at the turn of the century:

The social purity movement was a loose network of organizations and individuals, mostly church people, educators, doctors, and those we would now describe as community or social workers, who engaged in a sporadic but vigorous campaign to "raise the moral tone" of Canadian society, and in particular of urban workingclass communities. (p. 17) 
Influenced heavily by the church, in Canada "purity work" was carried out by "already existing organizations devoted to moral, social, religious, and/or gender reform work" (Valverde, 1991, p. 51). Although these groups were largely voluntary bodies outside of government, they "interacted heavily with the state" and thus had the ability to influence policy and legislation (Valverde, 1991, p. 52).

\section{2 - The rise of maternal feminists: Women as civic housekeepers}

A dominant theme in the research literature on the Canadian suffrage movement is its reformist nature and commitment to social purity (Bacchi, 1983; Kealey, 1979; Prentice et al., 2004; Valverde, 1991). Bacchi (1979) states that one cannot look at the suffrage movement in isolation from this: "Woman suffrage was a part of the package due to the conviction that good, pure, Christian, middle-class womanhood would help vote in the legislation required to control a decadent society" (Bacchi, 1979, p. 90). Women were central in the North American reform movement, and Kealey notes that suffragists argued that their "womanly" qualities - a nurturing nature, selflessness, and good household management skills - would make women outstanding citizens if they were granted the vote.

One of the most iconic Canadian suffragists, Nellie McClung, championed this viewpoint. McClung (1972) believed that motherhood was a responsibility of women, and that if womens' role as mothers were extended to public life reform would be possible:

The hand that rocks the cradle does not rule the world. If it did, human life would be held dearer and the world would be a sweeter, cleaner, safer place than it is 
now! Women are naturally the guardians of the race, and every normal woman desires children. Children are not a handicap in the race of life either, they are an inspiration....It is not so much a woman's duty to bring children into the world, as to see what sort of a world she is bringing them into, and what their contribution to it will be. (p. 22-24)

According to McClung, women had two roles: to have children and to use their motherly qualities to create a world where they would want their children to grow up.

Theorists have described the above approach as "maternal feminism." Maternal feminism advocates that if women were involved in public life they could improve social conditions because of their inherent qualities; it was a woman's role as a mother that qualified her to be a protector of society (Bacchi, 1983). Kealey (1979) defines maternal feminism in a similar way, but adds that this particular form of feminism "de-emphasizes or subordinates personal autonomy in favour of a (relatively) wider social role" (p. 8). Stemming from biological determinism, maternal feminism does not advocate equality of the sexes, but presumes that women have a specific role in society that is separate from men's. Lavigne, Pinard and Stoddart (1979) argue that because maternal feminists consider sex an essential difference between men and women, the majority of suffragists did not challenge prescribed gender roles:

The definitions of male and female roles were never questioned. This first generation of feminists believed men and women were complimentary rather than equal beings and they defined the social role of women accordingly. They were content to attack the discrimination resulting from the division of men's and women's roles without questioning the full meaning of this inequality. At no time 
did their actions or writings reveal a search for the underlying causes of women's oppression. (p. 75)

The maternal feminist perspective was dominant in the suffrage movement, but it was not the only collective viewpoint that existed about why women should be granted the vote. "Equal-rights" or "equality" feminism also emerged during the first wave of the women's movement (Prentice et al., 2004). The foundation of equality feminism is that it is an injustice for women to have fewer rights than men; justice, not biology, is central. Equality feminism argues that although they may be of a different sex, women are human beings just like men; the only hindrance to women participating in public life is "custom and law" (Prentice et al., 2004, p. 190). For equality feminists, the vote became the "symbol of citizenship" (p. 190). The belief was that social and legal reform would result in the equality of the sexes (Krook \& Childs, 2010). Having highlighted and campaigned on the features that made them unique, maternal feminists never presented themselves as equal to men in the way that equality feminists did.

Carol Lee Bacchi's book Liberation deferred? The ideas of the English-Canadian suffragists, 1877-1918 interrogates our assumptions about "early feminists" who embraced maternal feminism. Bacchi argues that because of their links to the period's social reform movement, women's groups in this era were not nearly as radical when it came to challenging traditional gender roles as many have assumed. The typical suffragist tended to be white, middle-class, educated, religious, lived in a city and belonged to a reform group, such as the Women's Christian Temperance Union (WCTU), the Winnipeg Women's Civic League, or the McGill University Women's Club (Bacchi, 1983). As an almost exclusively Anglo-Saxon movement, the majority of Canadian 
women - such as those who were working class, non-white, and lived in rural areas were excluded from what was presented as a gender-based struggle ${ }^{4}$.

One group that was actively excluded from the rights that the suffrage movement aimed to achieve was women with disabilities. Reform associations such as the WCTU and National Council of Women of Canada (NCWC) had specific committees to deal with perceived problems relating to those with disabilities. For instance, in 1912 members of the NCWC Committee on the Equal and Moral Standard and Traffic in Women argued that feeble-minded women became prostitutes and that they passed such traits onto their "illegitimate" and "defective" children (Valverde, 1991, p. 94). Coming from a mentality that relied on eugenics and wanting to protect the genetics of their race, the Committee on Feeble-minded Women called for the institutionalization or sterilization of women who were of child-bearing age and "fell under the vague category of feeble-mindedness" (Valverde, 1991, p. 94). Although suffragists generally supported the environmentalism approach, as opposed to eugenics, women with disabilities seemed to be one area where women supported eugenics. Bacchi (1983) writes, "Many suffragists admitted that environmental reform had a limited effect on mental capacity and therefore it might be necessary to regulate breeding of the retarded" (p. 108). That suffragists took such a specific approach regarding the rights of those with disabilities highlights how women with disabilities were being excluded from the suffrage cause.

\footnotetext{
${ }^{4}$ While in some provinces, such as Manitoba, women suffragists frequently worked in conjunction with farmer associations and trade unions, the membership of associations that focused exclusively on suffrage - such as the Canadian Suffrage Association and the Montreal Suffrage Association - were predominately white, middle class, educated, and lived in urban centres.
} 
Although necessary in highlighting social factors previously overlooked by scholars such as Cleverdon - particularly when critiquing the racist, class-based and exclusionary undertones that shaped Canada's suffrage movement - Bacchi's overall analysis is not without problems. Bacchi asserts that it was not the goal of suffragists to "restructure sex roles", but instead that gaining the vote "offered women a new political status and it raised public awareness of the mothers' contribution to the race. But it reinforced sex role stereotypes which have proved difficult to remove" (p. 148). Bacchi cites studies, which document that following enfranchisement few women participated in politics or ran for election, and women continued to be segregated into specific "motherly" jobs such as nurses and teachers. While fair in making an assessment that the first wave of the women's movement did not change how women were, in many ways, defined and restricted by their gender, she seems to dismiss the importance of suffrage, its impact on changing the legal status of women, and the influence it had on current women's rights.

Bacchi (1983) fails to account for the fact that this particular legal reform women gaining enfranchisement - was itself progressive for the time. Suffragists may not have entirely done away with traditional gender roles, and it is true that the first wave of the women's movement did a disservice to many women. Those that were not of the Anglo-Saxon race and had disabilities were marginalized, and the work of women suffragists represented a "small elite within the general female population" (Bacchi, 1983, p. 110). Yet what many men and women were doing during the first wave of the women's movement was indeed profound (when looked at in context of the era), and should not be so easily cast aside as conservative and moderate. 
Maternal feminism isn't necessarily radical when looked at in the context of its essentialist assumptions, but at the turn of the century the "new woman" still challenged the traditional behaviour and goals of women. This "astonished, amused and frightened most Canadians in the period before the First World War" (Roberts, 1979, p. 15). Suffragists struck a balance between the rejection of some feminine qualities that women had previously been associated with - such as "frivolity, passivity, subordination and [the] privatized familial role prescribed for them" - and an embrace of the motherly qualities they were assumed to have (Roberts, 1979, p. 18). Suffragists aimed to convince the general public and politicians that if they were granted the right to vote they would be model citizens.

Most early suffragists were maternal feminists, yet some broke from this mold, such as Flora MacDonald Denison, the president of the Canadian Suffrage Association from 1911-1914. Denison, a lower-middle class dressmaker who lived in Toronto, supported birth control and divorce, did not champion temperance, and was publicly critical of mainstream religion. She also self-identified as a feminist, which was rare for women in this time period, and resulted in academics like Gorham (1979) calling Denison a "radical figure" within the Canadian women's movement. Gorham's historical sketch of Denison highlights that the Canadian suffrage movement was not simply a uniform campaign that promoted one homogeneous position on the various social issues of the time. As Gorham writes, "Denison's radical views on sex and marriage, coupled with her unorthodox ideas about religion place her in a tradition of revolt against puritan respectability ... that was present to some degree at the turn of the century of Canada" (p. $67)$. 
While most literature (Bacchi, 1983; Roberts, 1979) highlights the conservative, maternal nature of the suffrage movement, Denison's story demonstrates that the reformist approach to suffragism - even if it was the most popular - was not the only one:

Much, but not all, of Canadian women's activism fits this picture of conservative social reform. But in the period before World War I, some women, like some men, had a more radical vision than that implied by social gospel reformism; and some women had more radical views about the position of women than those implied by the demands of conservative 'maternal' or 'social feminism'. (Gorham, 1979, p. 48)

The fact that Denison held such a prominent position in the movement suggests that she had many supporters willing to accept her as a figurehead despite her break from the mainstream ideologies of the time.

\section{3 - Canadian suffrage organizations}

A central feature of women's organizations in Canada in this period is that, while they supported the enfranchisement of women, many of those involved in the campaign were not exclusively focused on this cause alone. Even Canada's premier suffrage organization - The Toronto Women's Literary Club, founded in 1876 - was not initially formed as a suffrage group, but as a club that dealt with diverse issues surrounding the advancement of women. Some historians such as Cleverdon(1974) suggest that the group distanced themselves from the word suffrage because it was too 'bold', and used the name "literary club" to mask their true activities. Either way, it was not until 1883 
that the Toronto Women's Literary Club was disbanded and re-formed as the Toronto Women's Suffrage Association, and eventually became the Canadian Suffrage Association (CSA) in 1907.

Some associations, such as the National Council of Women of Canada (NCWC) and the Women's Christian Temperance Union (WCTU) who advocated for suffrage were primarily reformist organizations. These associations had the goal of improving society through things such as a return to Christianity, puritan morality and strengthening the family (Bacchi, 1983).

Church affiliated groups including the WCTU, the Young Women's Christian Association (YWCA) and Methodist and Presbyterian organizations, were also early supporters of the suffrage movement (Bacchi, 1979). One of the most influential organizations advocating suffrage was the WCTU. With over 10,000 members across the country in 1900, the organization was larger than any suffrage association (Mitchinson, 1979). Initially the WCTU did not support suffrage; however, in the 1890 s, they became an advocate for it as a means to prohibition. The WCTU and similar groups saw enfranchisement as a tool to aid their political influence; believing that the way to gain power was through gaining the vote (Errington, 1988; Mitchinson, 1979).

There were also groups supportive of the suffrage movement that were not reformist in nature, such as the Toronto Labour Council and the Socialist Party of Canada. Such organizations further polarized the movement within cities, as there were divisions between labour and suffrage organizations (Bacchi, 1979). Although labour associations tended to support suffragism, suffragists often ignored and didn't fully integrate the working class in their policies. Bacchi (1979) and Roberts (1979) have 
suggested that such conservative practices hindered the early goals of women's suffrage and its widespread appeal among the working class and non-white Canadians. Yet, crossmembership between suffrage, women, and reformist groups provided a solid membership base for suffragism (Mitchinson, 1979). Suffragists themselves often belonged to reform associations: twenty-five per cent of woman suffragists and twentyseven per cent of men $^{5}$ were also members of temperance societies; thirty-seven per cent of woman suffrage leaders were active in reform associations such as Charity Organization Societies, societies to protect the "feeble-minded", child welfare associations, and social purity groups (Bacchi, 1983).

\section{4 - Suffrage unity: The National Council of Women of Canada (NCWC)}

Errington (1998) argues that the Canadian women's movement gained a sense of "national unity and group identity" under the NCWC. Established in 1893 by Lady Aberdeen, spouse of the then-Governor General, the NCWC was an umbrella organization and "strong lobbying group" created to oversee and address various issues impacting women. The NCWC did not initially advocate suffrage and described itself as:

"A federation of Societies and Associations of Women interested in Philanthropy, Religion, Education, Literature, Art, and Social Reform banded together for the furtherance of the Golden Rule" (National Council of Women of Canada, 1914). Prior to 1909 the NCWC was explicit in stating that they were not a suffrage organization; however, in 1910 they declared their support for women's enfranchisement, arguing that

\footnotetext{
${ }^{5}$ Men's involvement in the suffrage movement is often overlooked, yet there were many men who supported women's enfranchisement, were active in suffrage organizations, and held leadership positions. For more see Bacchi (1983).
} 
only when women had the right to vote, could they influence causes they were passionate about, such as labour and liquor laws, the protection of children, and the arts (Cook, 1974).

Although the NCWC brought together women across the country, there was some disparity, much of which stemmed from geography, about what causes the organization became involved in (Errington, 1998). Most members of the NCWC lived in urban centres; thus, the NCWC focused on city issues such as the influx of young single working women who were taking jobs in factories and living in urban centres. Rural areas did not experience social problems associated with urbanization, but these issues still remained a central tenet of the work that the NCWC focused on. In addition to this urban-rural divide, there was also an Eastern-Western divide in the country, which was reflected in the NCWC. There was a different industrial climate in the East, and many women in the West did not have the same social concerns. Those belonging to women's branches of the United Farmer's Association of Manitoba, Saskatchewan, and Alberta "distrusted the intentions of the urban-based, middle class reform groups, believing that they were but appendages of the industrial, political interests of the East" (Errington, 1998, p. 69). This accounts for why many of the NCWC's executive were from large Eastern urban centres, such as Montreal and Toronto.

The NCWC had both local branches - such as the Local Council of Women of Toronto and the Montreal Council of Women - as well as affiliated organizations, including the Women's Arts Association of Canada and the CSA. As affiliated organizations, the latter groups received space to print their yearly reports in the NCWC yearbooks, and had the opportunity to attend annual national meetings, which were held 
in a different Canadian city each year. Academic research has examined the polarization of the Canadian suffrage movement, noting the more conservative approach taken by the NCWC in comparison to the CSA (Bacchi, 1983; Roberts, 1979). Whereas the CSA always had the primary goal of suffrage, the NCWC "came to support [suffrage] not as a measure of democracy or women's rights, but as an enabling tool for pet social reforms" (Roberts, 1979, p. 22). Despite differences in their intentions, there were strong connections between the NCWC and the CSA. The CSA was an affiliate member of the NCWC for several years, and the presence of CSA executive members at the NCWC annual meetings ensured that suffrage was continually on the agenda of the National Council.

The NCWC belonged to the International Council of Women. Thus, Canadian suffragists were connected with similar women's groups throughout the western world. The International Council of Women held its Fourth Quinquennial Meeting in Toronto in 1909, and the NCWC sent delegates to various International Council of Women meetings throughout the 1910s.

\section{5 - A national movement?}

Many of the groups that claimed to be national organizations, such as the CSA and the NCWC, were actually urban and Toronto-based. Literature suggests that Toronto was both the founding city of the Canadian suffrage movement, as well as the hub of activity (Cleverdon, 1974; Bacchi, 1979). Toronto's Dr. Emily Howard Stowe, founder of the Toronto Women's Literary Club, is generally considered to be the pioneer of Canadian suffragism. Stowe was not only Canada's first woman physician, she pushed 
for Canadian medical schools to admit women, was a prominent lecturer, a voice in the press, and an advocate for women's municipal voting rights (Cleverdon, 1974). Stowe remained involved in the suffrage movement until her death in 1903 and her daughter, Dr. Augusta Stowe-Gullen, went on to become the president of the CSA until she retired in 1911. Even after retirement Stowe-Gullen remained a vice-president of the NCWC and chair of the national council's Citizenship Committee, a role that she held when both national and provincial suffrage were first achieved in the 1910s. Although Stowe and Stowe-Gullen saw many achievements for suffrage organizations throughout their careers, the Ontario-centric nature of the movement did not fully represent women across the country (Prentice et al., 2004).

Suffrage issues were split by region, and there was also an urban-rural divide. As expected, the concentration of most suffrage activity was in large cities. While suffragists in the province of Ontario established women's and suffrage groups (such as the NCWC and the CSA), those living in farm communities across the prairies tended to work within already formed organizations. For example, in Manitoba the provincial farmers organization, the Grain Growers Association, was an early supporter of suffrage (Bacchi, 1979). As a result many suffragists in Manitoba opted to join the Grain Growers Association, and did not become involved in the official suffrage societies such as the Manitoba Political Equity League, which would have had connections to other suffrage organizations across the country. Despite not being as active as Toronto or Montreal in the "national" suffrage association, Manitoba became the first province to extend the franchise to women. The Maritime provinces, in particular, were quite isolated from the Canadian movement, while suffragists in British Columbia tended to focus exclusively on 
suffrage rather than combining it with other issues (Cleverdon, 1974). When analyzing the differences between the organizational structures of suffrage supporters across the country, Bacchi (1979) observes that because suffrage organizations - such as the CSA and local chapters of the NCWC - were urban, they tended to concentrate on issues that were of importance to city-dwellers. As a result they often overlooked concerns of women in rural communities, further emphasizing that the suffrage movement in Canada was far from unified.

\section{6 - Suffragists in the city: Urban women at the turn of the century}

During the period of the first wave of the women's movement, Canada was undergoing fundamental reorganization in terms of labour and urbanization. Canada's urban dwellers went from 1.1 million (approximately twenty-five per cent of the population at the time) in 1880 to 4.3 million (fifty per cent of the population) in 1920 (Strange, 1995). As the number of urbanites rose, they tended to move to large cities such as Montreal or Toronto. Toronto experienced rapid growth in the 1910s, and was catching up to Montreal - the largest Canadian city and considered the country's "premier urban centre", a reputation it earned in the late nineteenth century (Strange, 1995). It was these cities with exploding populations - many of which were immigrants and women who were coming to these urban centres to work - where social problems became a concern and thus made them prime sites for reformist concern.

As Strange argues "the city presented a moral threat to urban and rural Canadians alike" (p. 4). In particular it was the young, single working women who were migrating to urban centres that became a cause for concern. Strange writes, "With the rise of 
commercial amusements geared towards working-girl customers, then, the wage-earning single woman became less a force for pity than a target in the campaign to establish moral order in an urban industrial context" (p. 15). Women's reform groups - such as the YWCA and the NCWC - became focused on the morality of these working women, and began implementing programs in an attempt to regulate their leisure activities, wages, and sexuality. For instance, the YWCA formed as an evangelical public institution for "respectable women", and it was here that women gathered and discussed the problems of the city (Pedersen, 1996). The YMCA sought to offer alternative leisure activities, in the forms of cafeterias, gymnasia and swimming pools, to young women who had a variety of entertainment available to them.

Montreal had additional features that made the situation somewhat distinct from that of other urban centres such as Toronto. Despite the size of Francophone population in Quebec the suffrage movement in the province initially was entirely Anglophone and almost exclusively concentrated in Montreal (Cook, 1974). This stems from the English control of industrial growth in the province. Similar to the rest of Canada, upper middleclass women dominated the suffrage movement in Quebec. Because the English were in control of the province's development, Quebecois suffragists tended to be English (Lavigne, Pinard \& Stoddart, 1979). In a province where ninety per cent of the population was French, the dominant women's advocacy group - the Montreal Council of Women communicated in English (Cleverdon, 1976). In 1907 the Fédération Nationale SaintJean-Baptiste (FNSJB) was established and gave Quebec women a French-speaking suffrage organization to join (Cook, 1974). Lavigne, Pinard and Stoddart (1979) suggest that the central issue in Montreal during the suffrage campaign was the desire to fix 
social problems associated with industrial capitalism and urbanization in Quebec. English Canadians controlled the recent industrialization in the province, which resulted in a French-English divide. This division was evident in the suffrage movement; the FNSJB was established to offer an alternative to Francophone suffragists. Like the English organizations, FNSJB was active in causes associated with urbanization and advocated suffrage as a solution to many of the city's social problems.

\section{7 - Getting the vote}

When it comes to enfranchisement, the 1910s was the most active decade for suffragists. It was the period in which the movement was gaining public attention and suffragists began to see concrete results. As Cleverdon (1974) documents, the first province to extend suffrage to women was Manitoba in 1916, and just a few months later women's enfranchisement laws were passed in Saskatchewan and Alberta. By 1917 women could vote in British Columbia and Ontario; Nova Scotia in 1918; and New Brunswick in 1919. Prince Edward Island followed suit in 1922, and Newfoundland ${ }^{6}$ in 1925. It was not until 1940 that Quebec women achieved the franchise, despite having associations (such as the Montreal Council of Women, the Montreal Suffrage Association and the FNSJB) that were bringing attention to enfranchisement issues for just as long as suffragists in Ontario.

Academics have offered various theories regarding why it took until 1940 for the province to pass suffrage legislation. Cleverdon's (1974) and Lavigne, Pinard and

\footnotetext{
${ }^{6}$ At this time Newfoundland was not officially part of Canada, as they did not join confederation until 1949.
} 
Stoddart's (1979) research highlights the influence of the Roman Catholic Church in Quebec, suggesting that attacks from the clergy - who saw suffragists as a threat to family values - potentially influenced the province's resistance to women's enfranchisement; "The extensive anti-suffrage campaign waged by conservative forces led Catholics to believe that advocating the vote for women was contrary to church doctrine" (Lavigne, Pinard \& Stoddart, 1979, p. 79).

In addition to offering a suffrage community for Francophones, central to the FNSJB was its adherence to Catholic values. At the time the Church was "attempting to impose a rigid code of puritanical ethics on Quebec society" (p. 77). Not wanting to break ideologically from the Church, "The Fédération gradually dissociated itself from the most controversial political and professional demands, withdrew further from the influence of the progressive reform movement and became increasingly influenced by Catholic feminism" (p. 75). Catholic feminism refers to the Church's desire to have women involved in charities and women associations while still abiding to the teachings of the Catholic Church. "Family values" were considered to be extremely important, and this resulted in the church advocating for women to fulfill their traditional gender roles in the home (Lavigne, Pinard \& Stoddart, 1979). Although Protestant churches also favoured a traditional family structure, which most often involved women staying in the home, many Protestant ministers officially endorsed woman suffrage - such as the Methodist Conference and Presbyterian and Anglican synods - or even joined suffrage organizations (Bacchi, 1983).

This contradiction between the Church's anti-suffrage stance and FNSJB's adherence to Catholic values was problematic for the Fédération and they made attempts 
to fix this. After first campaigning to Quebec bishops to support the suffrage cause, the FNSJB's legal expert Marie Gerin-Lajoie travelled to Rome to ask the International Union of Catholic Women's Leagues to make explicit that "woman suffrage was not incompatible with Catholic doctrine" (p. 79). This had no effect on the bishop of Montreal's stance about suffragism. The FNSJB wanted to adhere to the church's values and so they withdrew from the suffrage cause.

Lavigne, Pinard and Stoddart (1979) also note that Quebec women were excluded from enfranchisement because it was thought that they would vote against conscription in the First World War. Cleverdon's research documents that while Quebec suffragists supported Sir Robert Borden's conscription policy they were vocally opposed to the Wartime Elections Act. While the Act gave the vote to women who were serving or had relatives doing so, it also stripped the vote from Canadians who were not of British descent, unless they had an immediate male relative serving.

Federally, suffrage was an issue discussed in Parliament as early as 1883 , yet no voting rights at the national level were extended to women until 1917. Although they were all defeated, Prime Minister Sir John A. Macdonald introduced suffrage bills in 1883,1884 and 1885 , which would have allowed unmarried women and widows who owned property to vote in federal elections (Cleverdon, 1974). Petitions brought forward by the Canadian Suffrage Association and the Women's Christian Temperance Union in 1894 and 1896 received some debate in Parliament, however, no concrete change resulted. Sir Wilfrid Laurier, the Liberal prime minister from 1896-1911, was a passionate supporter of suffrage throughout his tenure, but it was Conservative Prime 
Minister Sir Robert Borden's government who introduced and passed bills that enfranchised women at the federal level.

After initially allowing women relatives of those in the armed forces enfranchisement in 1917 as part of the Military Voters Act (as well as women serving in the war, usually as nurses), in 1918 the Women's Franchise Act was passed. It came into effect on January 1, 1919, giving the federal voting right to married and unmarried women who were British subjects, over the age of 21 , and had the qualifications which would allow a male to vote. For instance, in Quebec men still had to own property to vote, therefore women were also required to meet these property laws. The passing of this bill came after some resistance, especially from French-Canadian MPs. The two major critiques of the bill were that provinces would lose the power to determine who could vote at the federal level, and that "the enfranchisement of women would be contrary to natural order" (Cleverdon, 1974, p. 133). The Women's Franchise Act was also subject to debate at the senate level, where three senators made attempts to amend the bill and one senator labeled woman suffrage as "one of the regrettable errors of our time" (qtd. in Cleverdon, 1974, p. 133). After securing the vote in 1919, women could be elected to the House of Commons following the passing of the 1920 Dominion Elections Act, and in 1929 it was ruled that women would legally be considered "persons" (Cleverdon, 1974). Some work, such as Cleverdon's, argues that the efforts of suffragists, which involved mass groups of women and men coming together to advocate on behalf of women's rights, were essential in women getting the vote. Other academics suggest that it was not necessarily the activist work of suffragists that resulted in their enfranchisement but the political situation of the period. Most importantly, political 
support for Canada's role in the First World War was an important factor in why Canada passed enfranchisement laws for women, as the federal government believed that base support for conscription would come from women voters (Bacchi, 1983; Brown \& Cook, 1974; Kealey, 1979). While it is true that the government did need public support for conscription, it is impossible to know whether the government would have granted the vote to women without the advocacy role undertaken by suffragists.

\section{8 - Suffragists during wartime}

When Canada entered the First World War in 1914 there was an effect on the country's suffrage movement, as well as other progressive reforms (Errington, 1988). The war years became a key component of the success of the movement, as during this time women demonstrated their commitment to the country by filling men's roles on the farms and in the factory (Cleverdon, 1976). In 1917 and 1918 women were key sources of labour in the country's workforce, however, women's wages were twenty to thirty per cent lower than men's. Women's work was accepted as a form of patriotic duty, but the public sentiment was that only single women should be working outside the home, and that their involvement should not extend past the war years (Errington, 1988).

Many suffrage associations suspended their publicity campaigns during the war and instead focused on relief work. One example is the Montreal Suffrage Association (MSA) that formed just one year before Canada entered the First World War. The MSA needed to find ways to ensure that their new presence was not completely overshadowed by the war effort. They made a decision to freeze funds for public speakers, and instead worked with patriotic associations, such as the Khaki League, the Patriotic Fund, the 
Soldiers' Wives' League, and the Women's War Register (Bacchi, 1983). Yet, this does not mean that associations, such as the MSA, completely stopped their advocacy work. Suffragists organized events that blended their cause with patriotism. For instance, in 1913 the MSA put on the popular suffrage play How the Vote Was Won and exhibited the American suffrage film Your Girl and Mine to raise money for the war effort (Cleverdon, 1974). While funds collected at the Montreal exhibition of the film Your Girl and Mine were donated to the war effort, in the United States theatres that screened the film raised money for the suffrage cause. As the United States did not enter the war until 1917, American suffragists did not have the opportunity to contribute to the war effort in the same way.

When Canadian suffrage associations made financial contributions to waraffiliated charities, they also received publicity for their efforts. This did not go unrecognized by the public. Women were praised for their generosity and patriotism throughout the war, and were seen as important contributors to Canadian society. "The average Canadian was unstinting in praise and generous enough to admit that women had earned their right to help chart the nation's future course" (Cleverdon, 1974, p. 77).

\section{9 - Publicity approaches in Canada}

As suggested at the beginning of this chapter, for the most part Canadian suffragists were maternal feminists who took a non-threatening and conservative approach to achieving their goals. This is somewhat distinct from the two countries that had the strongest influence on the Canadian suffrage movement: Britain and the United States. 
The British movement for women's franchise is usually described as being "militant" in nature, as suffragists in Britain visibly challenged the status quo and staged aggressive demonstrations and protests (Bacchi, 1983; Cook, 1974; Cleverdon, 1974; Thieme, 2006). Canadians generally avoided the use of such militant tactics, as they tended to favour techniques such as petition writing and circulating literature. The British suffragists were often referred to as "suffragettes" in news stories and literature to distinguish them from the more "civil" Canadian suffragists (Tunstell, 1958). While British suffragists received much more media attention and took an aggressive approach in their campaigning technique, they did not receive full enfranchisement until nearly a decade after Canadian women.

Canadian suffragists were generally quite reserved; however, Katja Thieme (2006) argues that the Canadian suffrage movement was influenced by the newspaper coverage of British and American militant campaigns. Reports of extremist British militancy tactics were some of the only instances where suffragism was covered on the front pages of Canadian newspapers, as the movement didn't receive much attention in mainstream media. The Canadian media coverage of British suffrage activities gave suffragism national attention. Canadian suffrage news was typically confined to a newspaper's women's page, which served as the primary media space for suffrage groups and leaders to articulate their views (Lang, 1999).

In addition to newspaper columns by suffragists, Canadians preferred other nonthreatening techniques. Petitions were used frequently, with Bacchi (1983) describing them as their "most effective tool." Comparing the Canadian and British suffrage movements, Bacchi observes, "In general, Canadian tactics were cautious and 
undemonstrative, in keeping with the country's reputed character. Canadian suffragists staged mock parliaments, sponsored plays, arranged exhibits, sold postcards, and generally used more subtle methods of persuasion" (p. 34).

In April 1911, a suffrage play called How the Vote Was Won, was presented by the Toronto Suffrage Headquarters, Ltd., which was a propaganda agency formed by the CSA's president Flora MacDonald Denison (Cleverdon, 1974). The pro-suffrage play was very successful in Toronto, and soon the script was being used across the country. "[How the Vote Was Won was] eventually used at one time or another by almost every important suffrage group in Canada" (Cleverdon, 1974, p. 35). The use of artistic media to generate publicity was a very popular approach in the United States. American suffragists frequently employed creative means of publicity, such as circulating suffrage plays, songbooks and films (Shore, forthcoming 2013).

From the outset the Canadian suffrage movement was influenced by what happened in the United States. Emily Howard Stowe founded the first Canadian suffrage organization, the Toronto Women's Literary Club, after she attended a meeting at the American Society for the Advancement of Women in 1876 and wanted to see a similar organization in Canada (Cleverdon, 1974). Some American organizations, such as the Women's Political Union (WPU), took a militant approach similar to British suffragists, which was distinct from the techniques of the National American Woman Suffrage Association (NAWSA). Although the suffrage movement in the United States was fragmented because of these two different advocacy techniques, there were still mass demonstrations in the United States. Canadians were often represented at American suffrage events, such as a mass suffrage parade in Washington on the eve of the 
inauguration of President Wilson in 1913 (Bacchi, 1983; Cleverdon, 1974). Even though they had a significant presence at this large-scale American demonstration, there were no similar activities on Canadian soil (Bacchi, 1983).

One of the most important influences that both the United States and Britain had on the Canadian suffrage movement was an exchange of speakers. Canadians often hosted British suffrage speakers, such as when the leading figure in the British movement, Emmeline Pankhurst, came to Canada on speaking engagements in both 1909 and again for a wider tour in 1911. Americans such as Dr. Anna Howard Shaw and Susan B. Anthony came to Canada several times to deliver public lectures on suffragism (Cleverdon, 1974; Kealey, 1979). In addition to speakers crossing the CanadianAmerican border, at least ${ }^{7}$ two suffrage films travelled from the United States to Canada. These films, which were produced by American suffrage associations in conjunction with production companies, were an important form of alternative media in the United States' suffrage movement.

${ }^{7}$ Based on primary research of Canadian suffrage archives there are only three mentions of Canadian screenings of American suffrage films. See chapter four for more detail. 


\section{Chapter Two}

\section{Two distinct responses: Regulating and utilizing film}

When film emerged in North America during the early part of the twentieth century, it was unknown how this new medium would fit in North American life. In their earliest manifestation films simply documented short events, and these actualities were seen as a spectacle (Thompson \& Bordwell, 2003). By the 1910s feature length films with a narrative structure became more common, and "moviegoing became less of a novelty and more regular entertainment" reaching mass audiences (Thompson \& Bordwell, 2003, p. 37). The popularity of the medium raised concerns for many suffragists. By the mid-1910s efforts were made to regulate the spaces where films were shown and to ensure that the content of films were not in contrast to the central values of the North American reform movement. Regulation of vulgar and violent films was important, and reformists felt that educational films would help ensure that the new medium did not corrupt audiences, especially children.

Although initially critical of film, American suffragists utilized it to convey important political messages. Co-produced with studios, American suffrage films became a form of alternative media used for advocacy. Research examining these alternative media productions provides context for discussing the importance of suffrage filmmaking, and the exhibition of suffrage films in Canada.

\section{1 - The emergence of film in North American culture}

Charney and Schwartz (1995) refer to cinema as an "emblem of modernity" suggesting that the evolution of film - including its reliance on the mass audience - was 
made possible because of particular social changes ushered in by modernity, notably the influx of people to the city who desired mass entertainment. Film became a central component of the culture of the city, as it was a medium that "addressed its spectators as members of a collective and potentially undifferentiated mass public" (Charney \& Schwartz, 1995, p. 10). Other aspects of urban culture also impacted the presence of film at the turn of the century:

Cinema did not simply provide a new medium in which elements of modernity could uncomfortably coexist. Rather, it arose from and existed in the intertwining of modernity's component parts: technology mediated by visual and cognitive stimulation; the re-presentation of reality enabled by technology; and an urban, commercial, mass-produced technique defined as the seizure of continuous movement. Cinema forced these elements of modern life into active synthesis with each other. (Charney \& Schwartz, 1995, p. 10)

The historical and social importance of film is not simply contained within the motion pictures themselves and the messages they conveyed, but in how they were consumed (Rabinovitz, 1998). Rabinovitz notes, "Like its urban contemporaries - the international exposition, the department store, and the amusement park - cinema was a site specially produced for a combination of leisure, spectacle, social encounters, commerce, and cultural education" (p. 1).

Historian Mary Ryan (1990) explores the development of what she calls "semipublic spaces" in the late nineteenth century. Such spaces - which included department stores, theatres and other sites of commercial amusement - were specialized and often built around consumption. She argues that these spaces were not "public" in the 
traditional sense, such as a city street or public park, because they were often privately owned and regulated by individuals such as theatre owners. Because there was some form of regulation in these spaces, semipublic spaces "facilitated a more decorous and controlled manner of interaction between strangers" (Ryan, 1990, p. 62). Movie theatres can be understood as semipublic spaces, acting as both sites of leisure activity and commercialism, as theatre owners encouraged women patrons as paying consumers.

The movie theatre was not limited to any one class or age: married women incorporated moviegoing into their shopping routines, schoolgirls went during the afternoon, and urban workers used the theatre as a place to escape their domestic responsibilities and families after work (Hansen, 1991). Although class, race, age and marital status are often important factors in terms of who has access to leisure activities (Scraton \& Watson, 1998; Shaw, 1994), research suggests that women across a wide range of social categories were attending the cinema in the early 1900s (Ewen, 1980; Hansen, 1991; 1983). Although there are no specific data offering a gender breakdown of audiences, research suggests that the majority of film patrons in North America at this time were women and children (Abel, 1995; Ewen, 1980; Rosen, 1973). By some estimates up to three-quarters of the 200,000 patrons that were attending New York City nickelodeons on a daily basis were women and children (Rosen, 1973).

\section{2 - Reform and uplift: Regulating film}

Abel (1995) writes that women and children "made up the greater portion of nickelodeon audiences across the [United States]" and these social groups were seen as especially vulnerable (p. 201). When debates regarding the "moral outrage" of film were 
taking place, "Women and children were always lumped together; rarely was the 'community' wary of the influence of movies on men" (Rosen, 1973, p. 24). Combined with a general anxiety about single working-class women who were migrating to urban centres at this time, there emerged a "concern about what effect 'going to the show' was having on such groups of people" (Abel, 1995, p. 202). Abel suggests that because of presumed media effects on a vulnerable population the debate about filmgoing "was framed in terms of moral uplift, class mobility, and gender hierarchy" (p. 202). If children and women were susceptible to media effects, reformers wanted to ensure that they weren't exposed to "dubious, even deviant, values and attitudes" (Abel, 1995, p. 203). Film was seen as a training ground for the "Americanization" of audiences, and at the heart of this was the assumption that the "function of fiction within mass culture was to generate positive models of imitation" (Abel, 1995, p. 203). Audiences were going to the cinema - according to the New York Times up to half the population of the United States was attending weekly - and reformists wanted to ensure that these audiences, especially women and children, were exposed to the "right" kinds of films.

In Canada, the assumption that films could influence children was widely accepted by the 1910 s, and as a result there were precautions taken to regulate the safety of theatres, and the morality of films themselves (Moore, 2008). Children were a special concern regarding the potential of moral corruption through film. Prominent Americans involved in the reform movement, such as Jane Addams, wrote about how nickelodeons and cheap amusements needed "reform and uplift," in addition to stricter policing of theatres (Moore, 2008, p. 58). The effect of this extended beyond the borders of the United States and had an impact on Canadian exhibition patterns as well. 
The desire to censor and "clean up" cinema was occurring throughout North America during the 1910s. Film scholar Eileen Bowser (1990) argues that Progressive Americans were aiming to improve various areas of American life, and that cinema was not exempt from this. "In Progressive America, people believed that all kinds of improvements were possible and inevitable. They were dedicated to winning the battles for women's suffrage, prohibition, organized labor, and world peace, and the battles of child labor, tuberculosis, and the household fly" (Bowser, 1990, p. 38). In the context of a wider North American moral reform movement, film was not the only medium subject to regulation at this time. Moore (2008) makes the observation that although films came under scrutiny from reform groups, other media were also heavily controlled in this era:

Standards of decency for audiences and the films they watched were still only implicitly a matter of everyday policing of all public conduct. The [Toronto] bylaw against indecency, before the first theatorium ever opened, already prohibited the exhibition, sale, or offer for sale of any indecent or lewd book, paper, picture, plate, drawing, "or other thing," and the exhibition within the city of any indecent or immoral show, exhibition, play, "or other representation." (p. 61)

The moral crusade to censor was already underway before moving pictures were ever introduced. Theatres, for instance, had been regulated for some time, and vaudeville plays were often pre-screened before they could be performed (Dean, 1981). Yet, the increasing presence of film in the lives of North Americans made the content and exhibition practices of film a prominent issue. 
Changes in the United States film exhibition industry between 1907 and 1915 included: new regulations to have nickelodeon theatres better lit, the increase in the number of women holding manager and usher positions (the belief being that they would bring a level of respectability to the theatre), and the frequent exhibition of educational films (Bowser, 1990). The formation of the Motion Picture Patents Company's (MPPC) licensing system in 1908 , which was headed by the two dominant film companies of the time, Edison and American Mutoscope \& Biograph (AM\&B), had an important effect on the quality of films being shown in American theatres. To play MPPC films, as well as use their patented equipment, all exhibitors had to pay a licensing fee. Following the establishment of a New York Board of Censorship, which soon changed its name to the National Board of Censorship, in 1909 the MPCC volunteered to have all of their licensed films approved by this body before exhibition. Bowser (1990) argues that the MPPC's voluntary regulation of film served a two-fold purpose in this context. It aimed to "uplift, ennoble, and purify" customers and to bring more business to theatres:

Progressive idealism did not conflict with their ideas of how to expand the market. To broaden the base of the audience, to bring in the middle class, and to make the movies a respectable place of entertainment for women and children, ... it would be useful to educate and uplift the immigrant masses and urban poor, who had made movies successful in the first place. (p. 38)

Although most films were regulated by the MPPC's voluntary system, there was still a thriving independent market in the United States. It is estimated that between 1905 and 1915 of the 8,000 theatres 2,000 refused to pay the MPPC licensing fee and distributed unlicensed films (Thompson \& Bordwell, 2003). 
American film exhibition practices, as well as the general North American reform movement, influenced Canadian regulation as well. Similar to the United States, the negative attitudes about the medium and its social harm impacted how film came to be regulated. The sentiment that many reformists had about the negative effects of film on society eventually resulted in the creation of censor boards across the country, most of which started at the local level. Many censorship boards were formed in the 1910 s - by 1911 Ontario, Manitoba and Quebec had the authority to censor films that were screened in public places (Dean, 1981). Canadian film scholar Malcolm Dean offers the only full account of censorship in Canada, and argues that at the turn of the century film was seen as "a very powerful amusement which was practically begging to be controlled" (p. 6).

Dean briefly cites an example of how a Canadian woman became involved in film regulation. Following the formation of the Ontario Censors Board in 1911 (which was the result of the provincial government passing the Theaters and Cinematographers Act) women expressed a desire to become censors. Dean writes, "Women were not long in noticing that all members of the board were men" (p. 136). In 1914 Ontario women went to the North American press and brought attention to the issue that women were turned down for censor positions. "In protest, applications flooded the Minister's office", and six years later Caroline Cassels became the first woman appointed to the Ontario Censors Board (p. 136).

Another example of a Canadian woman involved in film regulation comes from British Columbia. After applying unsuccessfully for the job of a provincial film censor in 1913, May Watkis approached the newly hired censor for the position of his assistant; he agreed as long as she acquired the necessary skills to also become a projectionist (Morris, 
1992). Though she initially struggled with training, as the B.C. projectionist union was not willing to teach the trade to a woman, Watkis was given the job. There was some protest against her initial appointment; however, she soon became an inspector for the Theatres Branch. In 1919 Watkis became the head of the newly formed B.C. Educational Patriotic Film Service, holding the title of "directress" (Morris, 1992).

These two examples suggest that during the 1910s individual women did not have a substantial influence on censorship at the board level. However, given the political and social rights of women at the time, the appointments of women to censorship positions were still notable achievements. Morris (1992) notes that when Watkis was hired as the censorship assistant women still did not have the vote in British Columbia. While there are specific examples of how individual women came to sit on provincial censor boards, there is still a lack of research that looks at the overall discourse of women's groups at the time and any impact they may have had on Canadian film regulation during the 1910s. Regulation was a key issue at the time, but films were not exclusively viewed as something that needed to be suppressed. Reformists promoted the use of film for educational purposes, as they hoped to influence audiences in positive ways. Suffragists in the United States soon extended this educative approach to their own cause, and produced alternative media to educate the public, through film, about suffragism.

\section{3 - Alternative media: The potential of film for advocacy}

As with other media forms such as newspaper, literature or art, film has the potential to be used for political purposes and to convey political messages. Film has particular qualities that make it an interesting medium for potential use by social 
movements. "Video and film's recapitulation and condensation of the separate strands of earlier media technologies - sound, print, animation, color, editing, imagery, artwork give them particularly rich possibilities in assisting the constitution and development of alternative public spheres" (Downing, 2001, p. 198-199). Canadian media activist Naomi Klein argues that not only do films have a strong emotional component, but because of the visual features of the medium they are often a starting point for discussion of important issues (Winton \& Klein, 2010). Klein argues that the characteristics of the medium make it a unique form of media: "I think it has to do with the collective experience of watching film and the idea of the screening being a community meeting in a way - the idea that it is the beginning of a community meeting" (Winton \& Klein, 2010 , p. $x$ viii). The ability of films to reach a mass audience in a shared space is important and contributes to the potential of film as a political tool, which can fall into the realm of alternative media.

Downey and Fenton (2003) write that alternative media, also referred to as nonmass, non-mainstream, radical, grassroots or community media, is generally reliant on citizen participation and has an important function in civil society. Yet they argue that the lack of clarity as to what is or isn't alternative media becomes overwhelming, and that alternative media analysis too often centres on description. Definitions of alternative media range from media that is in opposition to "mass media products that are widely available and widely consumed", media that has activism as its goal, media with specific "intents, effects, and processes" that involves open access and volunteerism on the production side; media that strives for "social change", to media that does not focus on profit as its motive (Waltz, 2005). Due to the variety of definitions Downey and Fenton 
(2003) believe that alternative media is both "under-researched and undertheorized" (p. 185). They seek to develop a theoretical framework to understand alternative media productions and their importance.

Alternative media is produced in what Downey and Fenton call the "advocacy domain." Building on Habermas's theory of the public sphere, Downey and Fenton distinguish the advocacy domain from the common domain of the public sphere. While the latter appeals to the general public, strives for universality, and is meant to be inclusive of all members of society ${ }^{8}$, "the advocacy domain consists partly of time and space made available by the dominant media and partly of a plurality of smaller civic media from political parties, interest groups, movements, organizations and networks" (p. 188). This is a key point about the advocacy domain: it does not exist in isolation from dominant media.

Applying Downey and Fenton's concept of an advocacy domain to film production, suffrage films can be understood as a form of alternative media produced in this specific domain. The activities of the suffrage movement fall outside of what Habermas considered the official public sphere ${ }^{9}$. As a social group that were not included in Habermas's common domain, the messages of suffrage films contained "subaltern discourses", which are "the ideas, languages, and arguments of individuals and groups

${ }^{8}$ Several critics have noted that Habermas's "inclusive" common domain in fact excluded the majority of people, as the public sphere was limited to bourgeois white men. In his later work Habermas adapted some of his original theories to reflect such critiques, proposing that alternative media had the potential to "support new groupings, providing information that can be discussed, or a mediated forum for such discussion" (Waltz, 2005, p. 18).

${ }^{9}$ Many feminist theorists argue that Habermas's theory of the public sphere is flawed because it does not address how gender is implicated in differential representation in the public sphere. See Fraser (1989) and Meehan (1995). 
who operate outside the established power structure" (Greenberg \& Gilberds, 2011, p.202). The use of subaltern discourses is a key feature of alternative media. Greenberg and Gilberds argue that "alternative media is politically radical and politically progressive - that is, should offer a vision of social reality that challenges oppression and expands democratic opportunities to economically and culturally marginalized individuals and groups" (p. 200).

Suffragists' general role in society fell outside the realm of the common domain, yet, they produced films in conjunction with those who were part of the official public sphere: film studios. Because American suffragists worked with production companies, suffrage films made in the United States during the 1910s were not do-it-yourself independent media. While recognizing the need to be flexible about how the term is applied when exploring alternative media, Greenberg and Gilberds define mainstream media as those which are "owned by corporations or supported directly by the state and which produce content for a general audience through technologies of mass dissemination" (p. 201). Mainstream media tend to carry dominant discourses, which represent the views of the powerful groups in society and do not generally challenge the status quo. According to this definition film studios certainly qualify as the mainstream media. Yet, in many ways, films produced by suffragists in conjunction with studios sought to challenge the dominant discourses of the time regarding the role of women and to what extent they should be involved in public life.

Thinking of suffrage films as alternative media in the way that Downey and Fenton (2003) describe - as something that is produced in the advocacy domain, which is often reliant on dominant media - can account for how the films were able to contain a 
political message in opposition to the dominant ideologies of the time, while still working within the confines of the film industry. Downey and Fenton argue that, "There are some opportunities in the public sphere (common domain) for citizens to perform an advocacy role. However, these opportunities are likely to be framed by the requirements of the mass medium" (p. 200). Thus, while suffrage films can be viewed as alternative media, the films adhered to particular constraints, notably storytelling devices. While making overt appeals for the suffrage cause, suffrage films still followed traditional narrative formats to appeal to audiences. For instance both Votes for Women and Your Girl and Mine were melodramas that featured standard conventions of this narrative form, most notably a love story as the central storytelling device.

Suffragists worked with studios, which no doubt shaped the final products. The backing of mainstream, or dominant, media for suffrage films is an important consideration. In the early days of film, studios were central in all aspects of a film's release, especially marketing; the studio brand was central in advertising new films (Shore, forthcoming 2013). The advertisements for suffrage films reflected the studio's involvement, as suffragists needed studios for promotion, production and distribution.

Votes for Women was made at Reliance Studios in New York City. Although Reliance worked in conjunction with the suffragists - the script was written by and starred leaders in American suffrage campaigns (Shore, forthcoming 2013) - the film was released by a studio, which is reflected in the advertisements for the feature film found in Moving Picture World (MPW) (Fig.1).

Your Girl and Mine advertisements also feature studio banners. A 1914 Moving Picture World advertisement states that Your Girl and Mine was the first release of the 
studio's Special Attractions Department, "under the personal supervision of "Al" Lichtman, formerly business manager of Famous Players, and Vice-President, General Manager and Organizer of the Alco Film Corporation." President of the National American Woman Suffrage Association's (NAWSA) Congressional Committee Ruth Hannah McCormick is credited as the lead producer of Your Girl and Mine, but the involvement of such a prominent film industry businessman is significant. Another section of ad copy reads, "Only features of extraordinary strength backed up by a mission will be handled in this department" (World Film Corporation, 1914). The World Film Corporation certainly played up their role in releasing features with a "mission", but also acknowledged that such films could be "a big money-making innovation for Moving Picture exhibitors" (World Film Corporation, 1914). Even with studio backing suffragists were central in the production of suffrage films (Figs.2\&3).

In addition to looking at suffrage films as alternative media because they were produced in the advocacy domain, there are other features that are important to consider when one labels something alternative media. Greenberg and Gilberds (2011) offer a set of four themes emerging in alternative media research, which can serve as a guideline to understand what should be defined as alternative: 1) That it is a tool of struggle, 2) a source of radical content, 3) a means of organizing cultural production, and 4) a channel for the expression of identity and voice.

Based on these four criteria suffrage films can be classified as alternative media. It is important to note that Greenberg and Gilberds rely on Downing's (2001) definition of alternative media. Downing describes alternative media as those, which "typically engage in efforts to create social, political, or economic change, and often promote a 
radical $^{10}$ agenda" (p. 200). Central in Downing's view of alternative media is that "context and consequences" are "primary guides" to understand what falls into the category of alternative media as "the edges" of what does and does not qualify "are almost always blurred" (p. x). Thus, while suffrage films certainly meet some of the criteria of alternative media, in other instances it is not always so clear.

Although this logic often stems from a place of technological determinism, Greenberg and Gilberds (2011) identify alternative media as a tool of struggle, meaning that the technology available influences if, and how, alternative media is created. The opportunity to participate in alternative media production, through "the coordination of collective mobilization and political action", changes with the development of new technologies (p. 204). Often it is new technologies, such as film, which "have increased and allowed citizens to demand changes to society and politics in ways that were previously unthinkable" (p. 204). Like Luther's ability to circulate pamphlets because the production of them was made possible by the printing press ${ }^{11}$, suffrage films could only come to be in the context of a specific type of film production. If films were not being produced in great numbers during the 1910s, and there was no desire to attract audiences to this new public entertainment, it is hard to imagine how suffrage films would have come into existence (Sloan, 1988). The opportunity for suffragists to address an audience

${ }^{10}$ Downing (2001) highlights the importance of using the term "radical", as opposed to simply alternative. He identifies radical media as that which is "generally small-scale and in many different forms, that express an alternative vision to hegemonic policies, priorities, and perspectives" (p. v).

${ }^{11}$ An early example of media as a "tool of struggle" comes from the early 16th century when Martin Luther's pamphlets were pinned on the doors of a Catholic Church, which helped spark the Protestant Reformation to revolution. These pamphlets were widely circulated because of the technology of the printing press (Greenberg \& Gilberds, 2011). 
in a particular way came about because of the emerging presence of film in North American society.

The second criteria of alternative media, that it is a source of radical content, addresses the message that is conveyed, as opposed to the technology used to create it. In this context, the difference between alternative and mainstream media is that alternative media content "challenges the values and perspectives of the political and corporate elite" (Greenberg \& Gilberds, 2011, p. 206). The importance of "progressive discourse" contained in alternative media "seek[s] to give a voice to the concerns and aspirations of groups that are usually marginalized by mainstream media" (Greenberg \& Gilberds, 2011, p. 207). The National Film Board (NFB) documentary Women on the March: The struggle for equal rights notes that "early motion pictures had a field day with the suffragettes" (Tunstell, 1958). Films that contained a pro-suffrage message were unique for the time, making them a source of radical content.

Thirdly, alternative media is a way to organize cultural production, which often involves horizontal organization as opposed to vertical. The key here is that not only is the content of media alternative, but also the way in which it is produced. While suffragists worked in conjunction with studios to make films, suffragists were still key players in content and creation, taking on central roles such as scriptwriter, star, and lead producer. Greenberg and Gilberds (2011) argue, "If the goal of a social movement is to eliminate class, racial or gender hierarchy, its media production should be organized in a way that reflects equality among all participants" (p. 210). As suffragists were aiming to eliminate a gender hierarchy, at least in terms of who had the right to vote, the involvement of women in the production of media is key. 
The final criteria that Greenberg and Gilberds identify is that alternative media serves as a channel to express identity and voice. By producing films suffragists controlled their own image and influenced how they were perceived by the general public. For Greenberg and Gilberds, this "voice" in alternative media studies is key, as it broadens the scope of inquiry and "shifts our analytical lens to the people involved in these projects, and the ways in which these people engage with others to achieve freedom through their own cultural practices" (p. 213). When defining suffrage films as alternative media, looking at the producers and their goals are central, "whether [those goals are] changing policy, influencing public opinion, experimenting with new modes of production, or developing collective identity" (p. 213). As I will explore in the next section, suffrage filmmakers aimed to do all of these things.

If we restrict definitions of alternative media to concentrate on the tools used, the radical content or the organization of production, the social action aspect of alternative media falls to the background. We fail to see how something was a form of alternative media in its particular historical context. For instance, if we were to take the definition of alternative media provided in the 2007 Alternative media handbook, the authors are explicit in qualifying alternative media as "always independently run" (Coyer, Dowmunt \& Fountain, 2007). By this logic suffrage films would not qualify as alternative media because suffragists worked with the mainstream media to produce their products. However, Greenberg \& Gilberds (2011) point out that "what we consider alternative at one time may become mainstream at another", and thus we need to ensure that intentions remain at the forefront of alternative media analysis (p. 213). The rationale and intentions 
suffragists had when making films, which are discussed in chapter four, further supports why suffrage films should be viewed as a form of alternative media.

\section{4-American suffrage films: A 'historical footnote' of great importance}

One of the first studies focused on suffrage films in the United States was by Norden (1986); prior to this research, suffrage films had only been mentioned in the context of a more general history of women and film, such as Rosen's 1973 book Popcom Venus. Norden's work offers an analysis of the suffrage film genre; he explores both mainstream industry films that depicted suffragists, as well as those co-produced by suffrage organizations. Prior to the First World War, Norden estimates that "literally dozens of films [that] dealt directly with the suffrage movement and other issues pertaining to women's rights" were made (p. 172). In films produced solely by mainstream companies suffragists were generally mocked. Norden notes, however, that while these representations may not have been positive, the mere presence of such characters in films brought attention and awareness to women's rights and the suffrage cause. Norden argues that even when the suffragists were not in control of the presentation of their image, such films still played an important role in the movement. He brings attention to the "sharp contrast" between how suffragists were represented in mainstream industry films, most of which were comedies, and in those that were produced in conjunction with suffrage organizations. There was a noticeable difference in the representations of suffragists on screen when suffragists were the ones using the medium as a channel to express their identity and voice. 
Following these anti-suffrage mainstream films that were released, such as For the Cause of Suffrage (1909), When Women Win (1909), The Men Haters' Club (1910), Coon Town Suffragettes (1911), Oh! You Suffragette (1911), and The Reformation of Suffragettes (1911), suffragists soon began making their own films. In conjunction with studios, organizations such as the New York Woman Suffrage Party (WSP), the Women's Political Union (WPU) and the National American Woman Suffrage Association (NAWSA) co-produced films that were not only targeted at other suffragists, but a mainstream audience as well. Norden (1986) writes:

Quite aware of the medium's formidable didactic and propagandistic powers, the feminists seized the opportunity and began making films themselves. In rather short order, a number of serious-minded films produced by various suffrage organizations began emerging amid all the mockeries, and they went a long way toward educating the public. (p. 175)

Notable about these suffrage-produced films is that although they were pro-suffrage, they still utilized traditional cinematic narrative structures of the era. The plots of suffrage films, which often focused on how suffragism was compatible within families and traditional societal norms and values, allowed films to have more widespread appeal (Norden, 1986). By "couch[ing] their suffrage statements within traditional melodramatic frameworks, [suffragists] were able to get their messages across without alienating the more conservative members of their audience" (p. 175). Norden concludes that although the genre was short-lived, peaking between 1911 and 1915, suffrage films made audiences aware of the suffrage movement, while presenting the cause as compatible with the social values of the time. 
In a 1981 article Sloan explores the comedies and melodramas about suffragism, and examines the depictions of suffragists on screen. The use of film within the suffrage movement was not restricted to melodramas and fictional stories. Sloan records how British suffragists, in particular, realized the potential of documentary-style footage for their campaign. In 1908, for example, suffragists in England invited a film company to record a rally they organized in Hyde Park. United States suffragists did something similar in 1912, and had the suffrage parade down Fifth Ave in New York City documented on film ${ }^{12}$. Sloan (1981) suggests, similar to Norden, that any cinematic publicity is good, noting "Whether the newsreels' image of suffragists was derogatory or sympathetic, suffrage became an immediate issue when it was projected on movie screens. The films might ridicule the suffrage movement, but its power could not be denied or ignored" (p. 417).

A characteristic common to films produced by suffrage organizations - Sloan talks about three films in particular throughout her research: Votes for Women (1912), 80 Million Women Want —? (1913), and Your Girl and Mine (1914) - was the attempt to counter the negative stereotypes of suffragists that were common in mainstream films. Sloan identifies three broad types of suffrage narratives that were most often employed in mainstream films; there were militant suffragists who left home and eventually went back to their families; there were questions and insinuations about the sexual orientation of suffragists as these characters often wanted to break up the romances of young, attractive women; and there were suffragists who tended to have a general anxiety about the world. When suffragists began producing pictures, the representation of women advocating for

${ }^{12}$ This footage was used in the suffrage-produced melodrama Votes for Women (1913). 46 
suffrage, not surprisingly, began to change. The suffrage characters in these films tended to be attractive and sympathetic, and romance was often a central feature of the plot (Sloan, 1981).

Sloan's discussion of suffrage films in her book The loud silents builds on her earlier work. She examines suffrage films in the context of what she calls the "social problem" film. These pre-First World War films relied on fictional stories to address and expose social problems such as poor working conditions, poverty, child labour and political corruption. While Sloan recognizes the importance of the suffrage film genre within social problem films (dedicating a chapter to suffrage films), she also notes that suffragists were not the sole group to use the medium of film to promote a political cause at this point in history. Special interest groups such as the National Labour Committee, progressive politicians, and women's rights activists such as Margaret Sanger worked with the film industry to produce films for exhibition. Sloan (1988) writes that this was "a period in film history when the motion pictures were seen as a medium that might be open to the public, particularly those with a cause" (p. 10).

Sloan's research suggests that social problem films flourished in the 1910s because companies were releasing at least "one reel a week." There was less of an economic risk to produce a short film that dealt with controversial issues as opposed to later decades when studios were making fewer feature length films. Additionally, by 1917 American films were being exported abroad, and their budgets tended to be much larger; up to the mid-1910s the United States focused on a domestic market and the majority of the films they produced had reasonably small production costs (Thompson \& Bordwell, 2003). 
It was in the context of the social problem film that many of those who were involved in the social reform movement - and had been critical of film - were now starting to see its potential to educate and sought to "re-form" the types of films being produced (Sloan, 1998). Jane Addams - one of the most well known individuals in the United States' reform and suffrage movements - initially spoke out against film, stating that moving pictures were a "debased form of dramatic entertainment" and depicted "a primitive state of morality" (Sloan, 1988, p. 11). Addams wrote that strict policing wasn't enough to monitor nickelodeons but that they needed "reform and uplift" (Moore, 2008, p. 58). The fact that three years after such statements Addams went on to star in the suffrage film Votes for Women demonstrates the shifting attitudes of many American suffragists. Addams, along with another prominent suffragist Dr. Anna Howard Shaw, was persuaded to become involved in the moving picture. As Sloan (1988) observes, "The times were changing, though, and Addams's mind had changed along with them. She and her colleague Shaw decided that film could be fought by film; old stereotypes of suffragists could be countered with a more realistic portrayal in melodramas" (p. 112). As the story of Jane Addams demonstrates, American suffragists were initially very critical of film but just a few years later, they embraced the medium and produced suffrage films.

Sloan (1981) documents how American suffragists used film as part of their publicity and recruiting strategy. Prior to the use of film, suffrage groups were innovative when it came to promoting their political cause. They experienced success with the techniques such as presenting suffrage plays, and by 1911 they were experimenting with new forms of technology, like projections, which they used in "slide and lecture" 
presentations. Given their reliance on visual and creative forms of propaganda ${ }^{13}$, "It seemed to be a logical next step for suffragists to enter the movie-making arena; their dramatic use of plays and pageants had proven effective, and they were already addressing nickelodeon audiences" (p. 424). As discussed in chapter one, Canadian suffragists were using similar dramatic means to garner publicity, such as performing suffrage plays across the country (Cleverdon, 1974).

Although noting that suffrage films fit into the wider genre of social problem films, Sloan (1988) argues that:

More than any other movement activists of the Progressive era, the suffragists attempted to use the cinema in a politically sophisticated manner. They found that the lively new entertainment form of the "photoplay" could be an exciting vehicle for their arguments - particularly because it reached into working class and, increasingly, middle-class audiences. (p. 109)

As part of her study on the presence of women in early cinema, Shelley Stamp (2000) explores suffrage films in the 1910s and brings to light important information not only about the production and content of these films, but also conditions surrounding their exhibition. Stamp links suffrage films to the overall trends of cinema and the women's movement at this time. During an era when theatre owners were aiming to give cinema more legitimacy as a cultural form, they sought to attract middle-class women consumers, who exhibitioners believed would make this new form of entertainment respectable and "high class" (Stamp, 2000).

\footnotetext{
${ }^{13}$ While the term "propaganda" is loaded and may carry negative connotations in contemporary society, throughout the 1910 s suffragists used this term to describe campaigns and strategies that they used for publicity.
} 
Importantly, for Stamp, while the film industry actively catered to women during the 1910 s - which is significant itself - suffrage films in particular disturbed the status quo. "[There was] industry anxiety about films which appeal primarily (or exclusively) to women. Admitting middle-class women into exhibition spaces was one thing: acknowledging that their presence might alter such sites was quite another" (Stamp, 1998, p. 10). The impact of suffrage films, in contrast to other films targeting women during this time (such as serials), is especially important because "suffrage films not only hoped to attract female customers; they also aimed to rally feminist viewers" (Stamp, 2000, p. 9).

Stamp $(1998 ; 2000)$ notes that suffrage films were not always exhibited in traditional ways, but that suffragists often travelled with the film and gave a public lecture prior to its screening. This exhibition style brought more attention to the political message of the film. The exhibition location of suffrage films was also somewhat unique, as some of them - such as Votes for Women - didn't just play in theatres, but in places such as churches, meeting halls, and outdoor fairs (Stamp, 1998). By screening their films in multi-use spaces, suffragists were able to present overtly political messages and do their best to influence audience reception. Suffrage films were not simply a vehicle to present their viewpoint to the general public, but were seen by suffragists as an important recruiting technique (Stamp 1998; 2000). 
Amy Shore's 2013 forthcoming book ${ }^{14}$, Suffrage and the Silver Screen, based on her $\mathrm{PhD}$ dissertation of the same title, is the most comprehensive study to date on suffrage films. Unlike Norden, Sloan and Stamp, Shore does not study suffrage filmmaking as one aspect of a wider trend (the genre of suffrage films, the social problem film, or women's moviegoing patterns) but focuses her research on examining those films made by American suffragists and evaluating the impact they had on the movement. Her research looks at how "this activist use of film was one of the first instances in the United States that a social movement recognized and harnessed the power of cinema to transform consciousness and, in turn, transform the social order" (Shore, forthcoming 2013, p. 1).

Shore theorizes links between suffrage organizations and the film industry as more of a reciprocal relationship, or "productive union" (p. 2). She documents how suffrage and cinema were both experiencing a great transformation and increased cultural relevance in the 1910s, and that links between the two were mutually beneficial; "Cinema helped generate communities of supporters for the suffrage movement while the movement helped recruit moviegoers to cinema" (p. 2). Theatre owners often worked with suffrage organizations, seeing them as an ally that could help give the new form of entertainment legitimacy.

While the suffrage movement was searching for a national audience, so too was film. Permanent theatres across North America were growing significantly in number. During the peak of suffrage film production - between 1908 and 1914 - theatres in the

\footnotetext{
${ }^{14}$ I was fortunate enough to receive a manuscript of Suffrage and the Silver Screen from Amy Shore, forthcoming 2013. Her PhD dissertation, which the book builds on, is available on ProQuest Dissertations and Theses.
} 
United States increased from between 8,000 and 10,000 to 14,000 (Sloan, 1981). The narrative structure of film was evolving during this period. By 1914 feature-films - as opposed to shorts - were increasingly popular, and two years later they were the industry standard (Keil \& Singer, 2009).

Such changes to the film industry influenced how audiences interpreted suffrage films. Filmgoing was no longer concentrated in only the largest cities: it catered to both localized urban audiences as well as national ones (Shore, forthcoming 2013). By utilizing this new mass medium, suffrage groups were able to create a national ${ }^{15}$ audience for these films. Shore argues that national entertainment produced by suffrage groups especially suffrage films - worked to "foster a coherent national image of suffrage and suffragists" (p. 16). Seen across the United States, suffrage films presented the movement as a unified cause and made suffragism a national issue that the expanding cinema audiences were exposed to.

While their approach and analysis of American suffrage films differs, all four suffragist film scholars discussed in this section make strong claims regarding the lack of overall knowledge about, and research on, suffrage films (Norden, 1986; Shore, 2010; Shore, forthcoming 2013; Sloan 1981; Sloan, 1988; Stamp, 1998; Stamp; 2000). Despite the existence of at least six ${ }^{16}$ films co-produced by American suffrage organizations and film production companies, when it comes to academic work - both in the area of film

${ }^{15}$ Considering the exhibition of American films in Canada, one could also argue that they worked to create a suffrage community that extended beyond the borders of the United States to Canada.

${ }^{16}$ These include lantern slide shows produced by the New York Woman Suffrage Party (1911), the kinetophone Votes for Women (1911), Suffrage and the Man (1912), the melodrama Votes for Women (1913), 80 Million Women Want -? (1913) and Your Girl and Mine (1914). 
history and the suffrage movement - few historians seem to be aware of these films. Although the women's suffrage movement and early film exhibition have links, within academia "suffrage filmmaking is considered, at best, a footnote in the history of feminist film" (Shore, 2010, p. 342). Studying suffrage films reveals information about the history of early cinema, as well as the cultural and political role of women at a particular historic moment. The existence of films produced by suffragists in the United States suggests that "first-wave feminists" became one of the first groups to employ the technology of film to promote a political cause (Shore, 2010). In the early days of film production, American suffragists formed partnerships with studios and created alternative media. This rich, yet mostly unexplored, history of suffrage film production in the United States made it plausible that suffrage films played a role in the Canadian suffrage movement as well. 


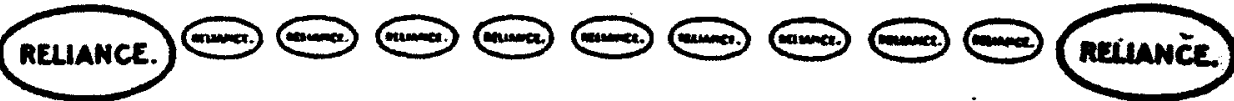

(i) The Box Office Scoop of the Season! (1)

(i)

(8)

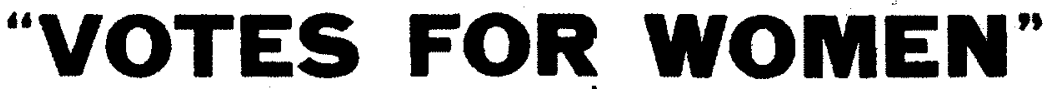

In Two Reels, Released Wednesday, June 26th

(8)

Has the support of every Suffrage organization in the country. They are already demanding it from their exhibitos, so Exchange men get buny.

Doctor Anna Shaw, Miss Jane Addams, Miss lnez Milholland, and

Doctor Anna Shaw, Miss Jane Addams, Miss Inez Milholland, and actually play parts. Special 3 and $I$ shoet poeters.

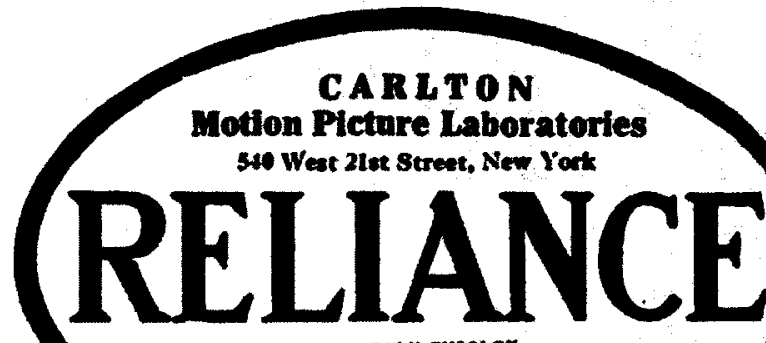

nes antr rmeces

Te Fila Supplis Compass of America 133 Weat 4th Struet
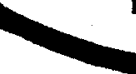
Now Yacte

And a cant including Hony Withall, jane Fearnley and Jamer Cooley.

Tenueby dramatic

A On mane rech Natural History woject -

THE PELICAN

Relensed Satwring, June ath Bofore The White Ian Bame

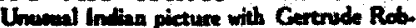
ineon ont bis cart.

Relewed Wodacodor, July 3nd MAN'S DUTY

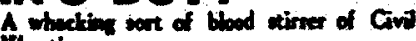
Wor tines.

COMTNG I "Rip Vas Wiakle," two reek, Satorday, Juj 6th CUIVING! "At Cripple Creek," two reels, Weduesday, Jaly 17th

(i)

A Two Reel Subject Once a Month and Erery One a Sensation!

RELIANCE.
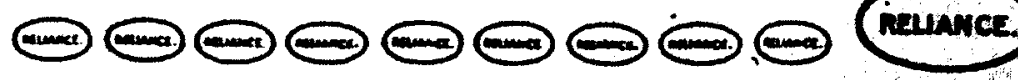

Figure 1: "Votes for Women." Reliance advertisement from Moving Picture World, April-June, 1912. PDF made available through Media History Digital Library. 


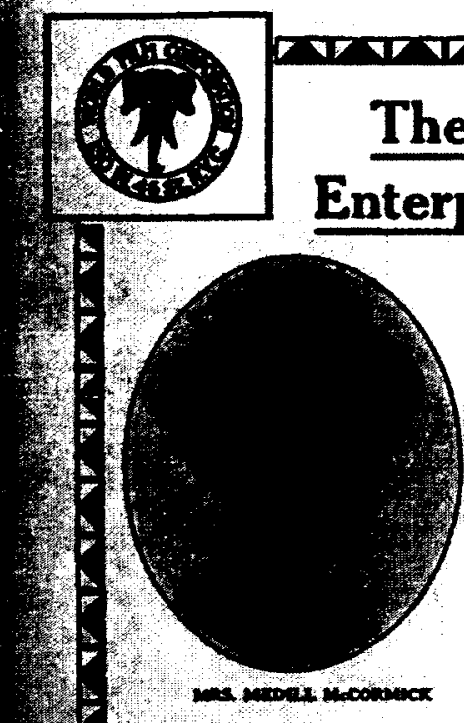

\title{
The Brains of Two Big
}

Enterprises Have Combined

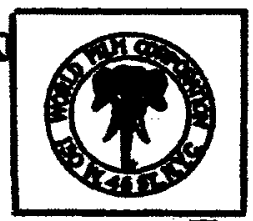

LEWLS J. SELZNICX

\author{
Has ARmancto \\ World Film \\ Corporation
}

carry out the idea that originated with MRS. MEDILL MCCORMICK, of Chicago, the executive head of the Woman's Suffrage Ascocia-

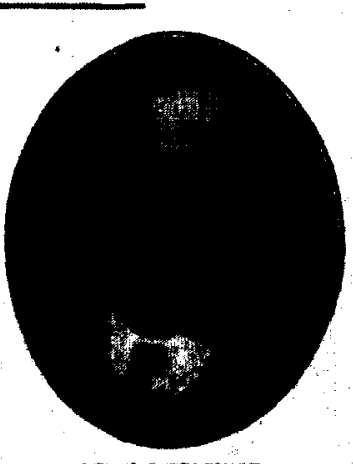

crows at mavicx

tion, to extend the cause of woman's sufirage by means of the sensational melodramatic feature,
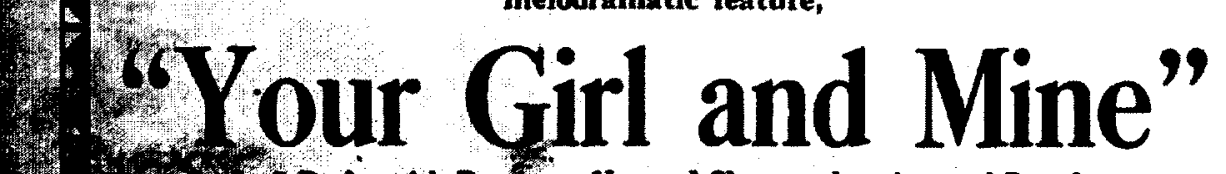

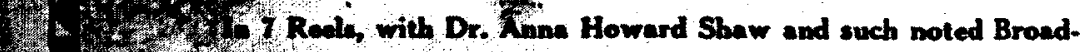

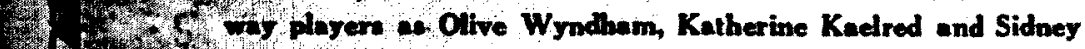

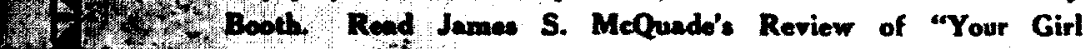

2.

1)

400,000 Women, Members of the Suffrage Organization, Are Selling Tickets Now. Your Audience is Ready.

Be the First to Take Advantage of This Tremendous Selling Force and Publicity

Ptowe or Whe On Noareat Brench Ofive for Furthor Dotails

WORLD FILM CORPORATION

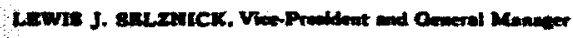
130 Weat 4Ch Street, New York

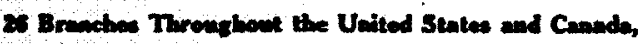

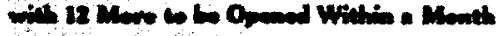

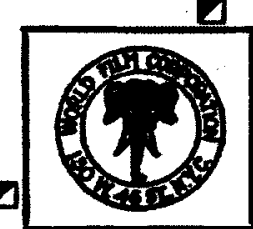

7r.

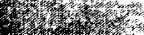

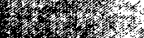

Figure 2: "Your Girl and Mine." World Film Corporation advertisement from Moving Picture World, October 3, 1914. PDF made available through Media History Digital Library. 


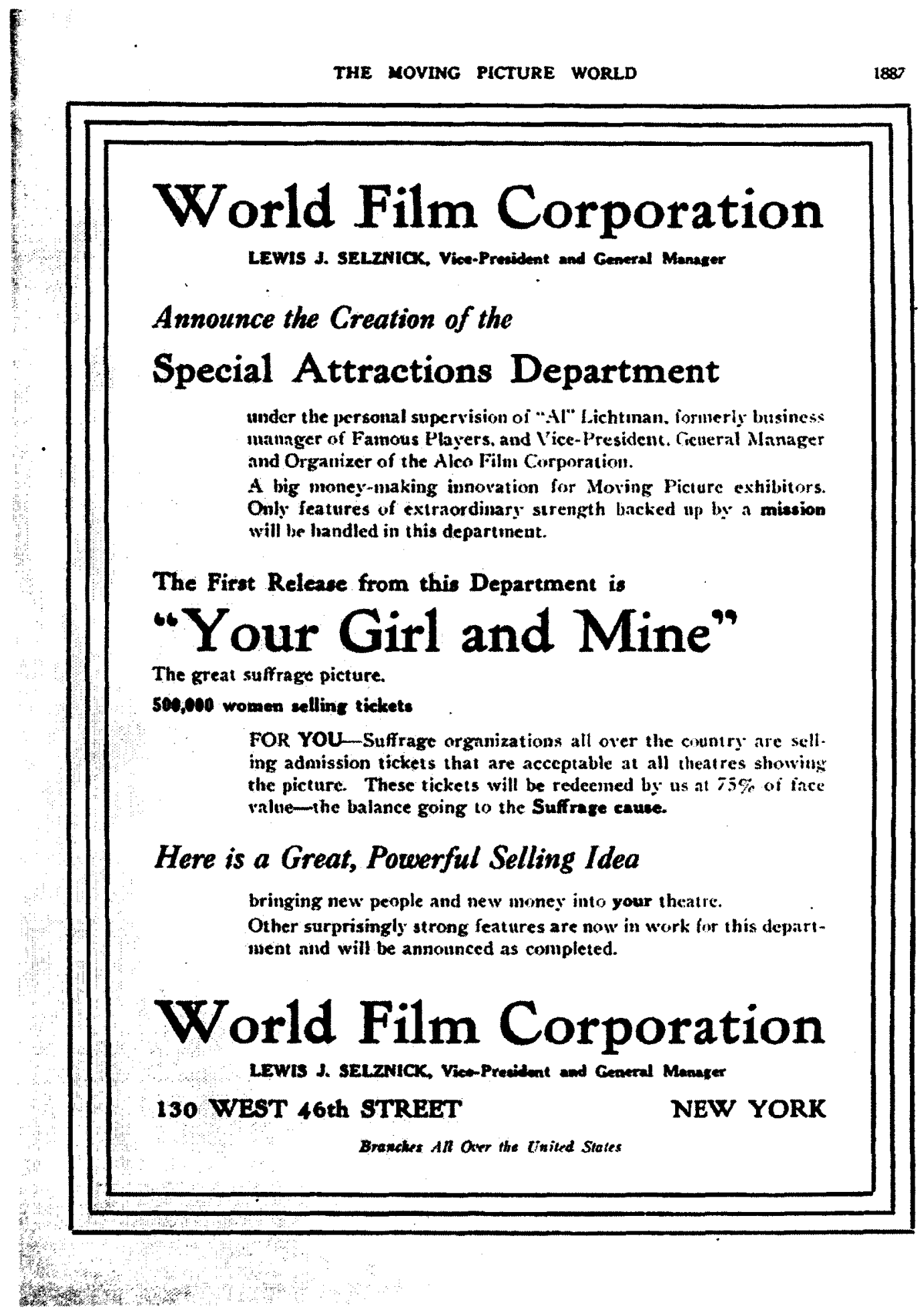

Figure 3: "Announcement: Special Attractions Department." World Film Corporation advertisement from Moving Picture World, October 3, 1914. PDF made available through Media History Digital Library. 


\section{Chapter Three}

\section{A nation of exhibition: The lack of Canadian suffrage productions}

The production of films by suffrage groups in the United States has been documented, yet there is a gap in academic research that looks at the connections between early Canadian film and the suffrage movement. Given the active role of Canadian suffragists in publicizing their cause and similar promotional strategies as American suffragists, it seemed plausible that Canadian suffrage organizations produced and exhibited their own films. Canadian suffrage associations gave lectures and put on plays to bring attention to their cause, so why wouldn't they have utilized the new and influential medium of the time like suffragists in the United States did?

An examination of the seven archives consulted for this project revealed no information, which would lead me to believe that Canadian suffrage organizations made any of their own films ${ }^{17}$. While material in the National Council of Women of Canada (NCWC), Montreal Suffrage Association (MSA), and the League of Women's Rights (Fonds de la Ligue des droits de la femme) archives make reference to the Montreal exhibition of American suffrage films, no sources mentioned Canadian suffragists

\footnotetext{
${ }^{17}$ I spoke with several researchers in the field that were unaware of any Canadianproduced suffrage films. Academics involved in the study of early Canadian film such as Charles Tepperman at the University of Calgary and Paul Moore at Ryerson University did not know of any suffrage films made in Canada. Likewise suffrage film scholars Amy Shore at State University of New York at Oswego, Shelley Stamp at the University of California and Madeleine Bernstorff, film curator and researcher based in Berlin, have not come across any evidence of Canadian suffrage films. Inquiries to the Film Reference Library (located at the TIFF Lightbox in Toronto) and Rosemary Bergeron (archivist of film/broadcasting at Library and Archives Canada) turned up no information about the existence of such films. These researchers cited archives of suffrage associations and the trade publication Moving Picture World as the best sources to help determine if Canadian suffrage films were produced. Archival research has not revealed any Canadian-made suffrage films.
} 
making films themselves. Two articles in Moving Picture World address a Toronto exhibition of an American suffrage film, but once again there are no references to films produced by Canadian suffragists. Additionally, Cleverdon (1974), who offers the most thorough account of the Canadian suffrage movement, does not speak of film production as a publicity strategy, although she does make reference to the Montreal screening of Your Girl and Mine. While it is possible that suffrage films were made in smaller provinces by organizations that were not consulted for this project, it is not likely given what is known about Canadian film production at the time. In this chapter I consider why there does not seem to be a similar use of alternative film in Canada as there was in the United States.

\section{1 - The absence of early Canadian filmmaking}

A probable explanation for the lack of Canadian suffrage film production stems from features of the Canadian film industry. Paul Moore's (2008) comprehensive account of Toronto's exhibition patterns from 1906 until the end of the First World War discusses how the Canadian film market has always been dominated by American productions, even in the days before Hollywood's global dominance. At the time of intense film production in the United States, in Canada few pictures were being made. Pre-First World War American production studios such as Vitagraph Company had a gross income of six million dollars and made 300 one-and two-reel films per year; "Canada had nothing comparable, but it did have a surfeit of wilderness landscape" (Melnyk, 2004, p. 22). When Canadian films were produced they tended to be "interest" shots of Canadian scenery, such as Niagara Falls and the Rockies (Gittings, 2002). The focus on landscape 
and agriculture is not surprising when one considers that one of the first uses of Canadian film was to create promotional documentaries, which had the goal of attracting settlers to the West (Melnyk, 2004).

As noted earlier, Sloan (1998) documented that, in addition to suffrage films in this period in the United States, there was an entire genre of "social problem films", focused on labour issues, the poor, children, and the "white slave trade." But in Canada, due to the overall lack of a film industry infrastructure, the social problem film was not a prominent genre. There were no films produced of this nature until the Ontario government ${ }^{18}$ became involved in educational film production with the establishment of the Motion Picture Bureau in 1917. The films produced by the Ontario Motion Picture Bureau ${ }^{19}$ were educational and tended to be specific to audiences. They were mostly exhibited in educational settings such as schools and churches, and although they were sometimes shown in theatres, they didn't receive much critical attention (Morris, 1992). For example, in 1921 the Ontario Motion Picture Bureau produced Her Own Fault, a film targeted at women factory workers. Her Own Fault used entertainment to promote good hygiene for female industrial workers living in Toronto. Shelley Stamp (1995) notes that this film was the Ontario government's way of "exploiting motion pictures and the field of commercial amusements", and that by doing this "the government shows its willingness to exploit new technologies for the purposes of social control" (p. 96).

${ }^{18}$ In 1918 the federal government established the Exhibits and Publicity Bureau, which did not focus on educational films, such as the Ontario government did, but on films that showcased Canada's landscape.

${ }^{19}$ Another key difference in the Canadian and American film industries at this time is that while provincial governments made educational films, in the United States social problem films were produced by privately owned studios. 
There were a limited number of private Canadian film companies in this period; however, the four that were established between 1912 and 1914 produced few pictures and did not last very long (Melnyk, 2004). The key reason behind the failure of early Canadian film production stems from economic challenges. Although production companies were appearing after 1911, "The Canadian domestic market was, simply, too small and the potential audiences too scattered across the country, for production to be viable without foreign release" (Morris, 1992). This accounts for why the four significant Canadian production companies established in the early-and mid-1910s often announced plans to produce films, which, in the end, did not always materialize (Morris, 1992). A significant constraint on domestic film production was that the population of Canada was geographically fragmented and small, and there was no central hub of production like there was in the United States. Canadian film historian Peter Morris (1992) writes:

Not only were the production companies strung out across the country, but so also was the population - and the potential market for the films. Combine this with the absence of an established theatrical tradition, the lack - or loss - of trained writers, actors, and technicians [to the United States], plus the difficulties in raising capital to finance inexperienced production and the impossibility of recouping that investment within Canada alone, and you end up with a pretty cogent case for not attempting any production in the first place. Indeed, it is perhaps more surprising that there was any production rather than that there was so little. (p. 54-55) 
Consequently filmmaking in Canada did not have an established presence as it did in the United States during the early part of the twentieth century. Given the lack of successful production companies in Canada it is not surprising that suffragists did not produce their own films. Even if suffragists recognized that film was a worthwhile medium to employ as a tool to spread their message, the logistics of production would have been much more difficult for them than their American counterparts. A lack of financially stable production and distribution channels no doubt had a hindrance on the feasibility of suffragists making films.

When looked at in context of the different infrastructure of the film industry it is not surprising that Canadian suffragists did not produce their own suffrage films, but instead exhibited those produced in the United States. This is consistent with research, which suggests that Canadians were content to "import" mass culture in large urban centres such as Toronto (Moore, 2008a). Toronto, in particular, would have been a prime location to screen American suffrage films. By 1915 Toronto had a larger film market than anywhere else in Canada; the city had "twice as many cinemas as Montreal and the largest moviegoing public in the country" (Pendakur, 1990, p. 54). Within the film industry Toronto was seen as an "ideal bridge between the United States and its global markets" (Moore, 2008).

\section{2 - Canadian exhibition of suffrage films}

I will now offer more detailed information about the two American suffrage films exhibited in Canada - Votes for Women and Your Girl and Mine - before turning to the design of my archival research. 
i. Votes for Women (1912)

Made at the Reliance studios in New York and released in 1912, Votes for Women stars two of the leading figures in the suffrage movement, vice president of the National American Woman Suffrage Association (NAWSA) and founder of the Hull House Jane Addams, as well as the president of the NAWSA Dr. Anna Howard Shaw. Reliance Pictures was one of several independent studios that formed in the fall of 1910 (Bowser, 1990). The studio made waves in the film industry (like other independents at the time) by recruiting top talent, including actors and directors, from larger studios. Prior to Votes for Women Reliance had made other films, which focused on social issues such as the pro-labour film Locked Out (1911). Despite playing a role in the creation of what Sloan has called "social problem" films, this does not suggest that Reliance had a commitment to activist media. Only a few months before Votes for Women was made Reliance released Bedelia and the Suffragette, a suffrage parody film. As Sloan (1988) suggests, "Reliance had, apparently, decided that both sides of the suffrage controversy could be profitable entertainment" (p. 111).

Votes for Women tells the story of Shaw and Addams as they convert a corrupt American senator's fiancé to the suffrage cause, which results in the senator finally seeing the need for political reform. Although the narrative of the film has the traditional features of a melodrama, such as a love story, as the central narration device, the call for suffrage is overt as Votes for Women presents the pros of granting women the vote (Sloan, 1988). Written by Mary Ware Dennett, a prominent American suffragist, Votes for Women highlighted controversial issues of the time, such as labour laws for working 
women, tenant regulations, neglected children, and political corruption. The message of the film was that if women were given the vote reform would take place: "Votes for Women established suffragists as the upholders of far higher ideals than government officials who profited from the very conditions the women sought to correct" (p. 112). Starring actual suffragists, Addams and Shaw's role in the film is significant. At a time when the American star system was emerging, Addams and Shaw brought their real life personas to the screen.

Votes for Women mixed fact and fiction, harnessing the popularity of melodrama to the sentimental drive of its civic housekeeping narratives....At the center of these melodramatic narratives were the figures offered up for identification - the suffrage stars of Addams and Shaw....At the critical moments in the film's narrative - when characters can either continue to support capitalist oppression or choose to support woman suffrage as the cure to the ills of capitalist society Addams and Shaw appear to provide character and audience identification and ensure conversion to the cause. (Shore, forthcoming 2013, p. 85)

Already well-established figures in the American suffrage movement, Shaw and Addams presented themselves to a national filmgoing audience. "The images of "real" suffragists onscreen served to marry local suffragists with a national cause. If local viewers who did not identify as suffragists prior to seeing Votes for Women chose to convert to the cause, they could become members of a national community....If they did not choose to convert to suffrage, they would at the very least recognize that woman suffrage was national news" (p. 136-137). 
Votes for Women was distributed throughout the "Northeast", travelled South and West, and in addition to cities such as Boston, New York, Baltimore, St. Louis, Los Angeles, and Portland, it screened in Montreal (Shore, forthcoming 2013). The film's popularity - exemplified by the fact that the reels were worn out in just two years - was an encouragement for suffrage organizations to produce more films (Sloan, 1988).

\section{ii. Your Girl and Mine (1914)}

The second suffrage film to screen in Canada was Your Girl and Mine, the final suffrage film made in the United States in 1914. A melodrama aimed at national audiences, Your Girl and Mine was produced by the then-President of NAWSA's Congressional Committee Ruth Hannah McCormick ${ }^{20}$. Like Votes for Women, Your Girl and Mine relied on prominent suffragists such as Anna Howard Shaw to promote the picture; however, it also utilized industry professionals, "extending the integration of the suffrage and cinema star systems" (Shore, forthcoming 2013, p. 196). Gilson Willets, the acclaimed writer of one of the popular serials at the time, The Adventures of Kathlyn, wrote the eight-reel ${ }^{21}$ melodrama, and when describing the picture McCormick claimed it to be "the largest moving-picture drama yet presented to the public" (p. 194). Critics praised the film for its cinematic value, such as early film critic Vachel Lindsay who commented that Your Girl and Mine advanced not only the suffrage movement, but also the medium of film (Shore, forthcoming 2013). The combination of production (there

\footnotetext{
${ }^{20}$ McCormick is credited as the lead producer of Your Girl and Mine; she signed contracts with World Film Corporation for national distribution (Shore, forthcoming 2013).

${ }^{21}$ In contrast Votes for Women was only two reels (Sloan, 1988).
} 
were 400 individuals involved in the project), screen time (the film was eight-reels, which gave it a longer running time than most) and intended distribution, made Your Girl and Mine a large-scale film for the era.

Your Girl and Mine was originally scheduled for widespread distribution in theatres across the United States; however, a disagreement between McCormick and the World Film Corporation resulted in the film's distribution being cut. Shore's research found no documented evidence of the nature of this disagreement, though she surmises that economic factors played a large role. Because NWSA was to receive a portion of the profits of Your Girl and Mine and suffragists could purchase discounted tickets, theatres may have been skeptical about booking the film, as their profits would be affected. The film was only shown in private screenings, and in 1915 McCormick gave Your Girl and Mine to NAWSA. One screening of the film was in Montreal. The exhibition of Your Girl and Mine by the MSA raised money for the war effort (all the funds collected at the screening were donated to the Khaki League) and gave the new suffrage organization publicity (Cleverdon, 1974). Aside from these few details, little is known about the Canadian exhibition of American suffrage films.

\section{3 - A gap in research}

As there is no previous research that focuses exclusively on the Canadian suffrage movement's use of film, this thesis will provide the preliminary study. American research on this subject (Shore, forthcoming 2013; Sloan, 1988; Stamp, 2000) offers a way to think about how film was used as a form of alternative media by suffrage organizations in the United States. A study in a Canadian context reveals information about the history of 
early Canadian film, and suffragists' use of alternative media. Although this topic has potential to be a rich area of analysis, I speculate that there are two main reasons why scholars have not yet explored if Canadians were involved in this process of suffrage filmmaking.

Firstly, the existence of suffrage films is not widely known. Although suffrage films have been written about in academia since the 1980s, the study of these films has often been peripheral and not explored in context of the suffrage movement. Shore's book, which provides the most comprehensive and focused account of American suffrage films, is still forthcoming. The most popular literature that examines the Canadian suffrage movement (Bacchi, 1983; Cleverdon, 1974; Kealey, 1979) was published before the original studies about American suffrage films were released. Therefore it is not surprising that scholars such as Bacchi, Cleverdon and Kealey were not specifically looking for information about Canadian suffrage film production. Secondly, there is little academic work that looks at the early history of Canadian film (see for example, Dean, 1981; Moore, 2008; Morris, 1992). This gap in literature stems from a lack of general Canadian film production; therefore there is little to analyze in comparison to the American or French film industries. There is also a lack of objects of study, as most silent films of the era, especially in places where little production took place, were not preserved. When taking these factors into consideration, accounting for an absence of research on this topic is not surprising.

Given this, I framed my archival research as an attempt to explore how Canadian suffragists responded to the emerging medium of the time: film. By studying archives of Canadian suffrage organizations and prominent suffragists, as well as the Media History 
Digital Library, I undertook historical research to better understand if, and to what extent, suffragists discussed the increasingly popular trend of filmgoing. Given the context of the reform movement of the 1910s, I sought to examine how suffragists were talking about film, and if this was done in a way that reflected the general values of the time.

Presuming that Canadian suffragists did not make any films of their own, such as those in the United States did, I aimed to better understand the context of the Canadian exhibition of American suffrage films.

\section{4 - Archival research design}

For this study I consulted various archives and specifically looked for any links between women's suffrage and film. While I was initially interested in any mentions of suffrage films in the archival materials, I also noted any discussions suffragists had about the medium of film or the activity of filmgoing. Previous literature documented that two American suffrage films had been exhibited in Canada during the 1910s (Cleverdon, 1974; Shore, forthcoming 2013, Sloan, 1988), but I had no further evidence to indicate if Canadian suffragists produced any of their own films. Because of this lack of knowledge on the subject, a historical archival study was needed to accumulate as much information as possible about any unknown existing links between the suffrage movement and film.

The method I utilized to examine the archival material was quite straightforward. When consulting all suffrage archives I looked through all of the records available, took note of any mention of the word "film", "moving picture" or "movie", and made detailed notes about the context in which the medium was discussed. Likewise when consulting trade publications any mention of the word "suffrage" was noted and the context of its 
use was described. By looking for these very explicit references, I was able to consult archives and stay focused on a narrow topic without getting overburdened by the vast amount of documents that many of these archives contained. Because I was unsure of what kind of information would be found in these archives, it was difficult to know prior to starting research how much material existed on suffrage film. I was unsure of how frequently suffrage archives would mention film and how common it was for suffragism to be discussed in film archives. The lack of Canadian literature on this subject meant that I was not searching the archives for predetermined patterns, themes or issues; rather, I was cataloging all links between early film and suffrage in order to have information that I could later analyze after all available materials were consulted.

Initially it was essential to confirm that Votes for Women and Your Girl and Mine were exhibited in Canada. In the archives I consulted in the Ontario-Quebec region, as well as an American media database, I only found evidence of two suffrage films being screened in the country. In the beginning stages of my research it was important to determine that the Canadian and American literature contained correct information about the exhibition of suffrage films in Canada. In particular, newspaper articles found in files of suffrage associations and individual suffragists' papers, as well as meeting minutes allowed me to retrieve necessary details about when and where the exhibitions of suffrage films took place.

\section{5 - Problems and challenges}

One of the primary methodological challenges of this research project was locating materials for analysis. As feminist historians have long known, women have 
often been left out of official records, which makes locating suffrage films created for and by women quite difficult (see Callahan, 2010). Film studies, too, has had challenges in offering a historical analysis of early film. Like most silent films of this era, few suffrage films were preserved and thus it is necessary to rely on newspapers, reviews, and other sources to learn even the basic plots of many suffrage films (Shore, forthcoming 2013). Not only were many of the films not preserved, but those that are located in archives are difficult to access. Of the two suffrage films exhibited in Canada, Votes for Women and Your Girl and Mine are both considered lost. Because of this obstacle, the actual films explored in this thesis were not viewed, and therefore I do not offer a textual analysis of them.

The lack of primary text is a problem for many researchers of early film, and the increasing trend in film history is to expand the object of analysis. For film studies, this means that researchers should not simply analyze films themselves, but examine what Anne Friedberg (1993) calls "screen practices." This involves looking at texts such as advertisements and news articles. In studying these, in addition to the individual films, we will be able to understand the broader filmgoing practice, which will allow for a more complete understanding of film's cultural significance. In addition to consulting newspaper clippings found in suffrage archives, I also examined advertisements and articles about suffrage films in the trade publication Moving Picture World.

Aside from a lack of archives of films themselves, for a long time film exhibition remained an unexplored area because of challenges relating to data collection. There are few surviving records of early film distributors and exhibitors, or comprehensive records of audience statistics (such as those broken down by gender or social class). Such data 
would be useful when analyzing audience attendance, and would foster a better understanding of who was attending suffrage films and how they might have influenced an early twentieth century audience. This lack of information about early film is further complicated in a Canadian context, as the early history of Canadian film is not very extensive, in terms of production and what has previously been studied.

Maltby et al. (2011) note that in the past ten years film history has become more focused on the examination of the medium as a "site of social and cultural exchange", as opposed to a study of the content of films themselves (p. 3). The authors term this interdisciplinary approach to studying film, "the new cinema history", intentionally avoiding the use of the phrase "film history." They see the need for scholarship in this field to study the role of cinema as a commercial institution, and the "socio-cultural history of its audiences" (p. 9). Though distinguishing new cinema history from earlier film studies research, Maltby et al. note that this new approach "complements and is informed by many aspects of film history" (2011.p. 9). By studying the previously unexplored presence of film as part of a prominent social, historical, and cultural movement, my study embraces the philosophy of new cinema history.

\section{6 - Description of the archives consulted}

One of the benefits of historical archival research is the array of sources that are included in the archives that extend beyond the films themselves. For this study several sources were key to answering the research question proposed above, such as official documents of suffrage organizations (yearbooks, meeting minutes, constitution, planned 
activities, etc.), biographical sketches of individual suffragists, newspaper and women's magazine articles, as well as film trade publications.

There is no comprehensive list of suffragist archives readily available, and thus even determining the existence and location of Canadian suffrage archives was a challenge. The archives of suffragists and organizations that were prominent in the large urban centres of the time (Montreal and Toronto) were essential to this study because a) that is where most suffrage activity was taking place at the time, and b) these cities sustained a vibrant film exhibition industry. I aimed for a variety of suffragist archives, while recognizing the constraints of both time and location. The Canadian Council of Archives website returns fifty records on the topic of suffrage. In total seven archives were selected for this project.

The archival research took place between September 2011 and January 2012. Following is the list of archives consulted that were selected for both reasons of accessibility as well as perceived use value. A brief description of some key materials contained in the archives and particular reasons why these specific holdings were consulted are also provided.

\section{National Council of Women of Canada (NCWC)}

Located at Library and Archives Canada (LAC), the NCWC archives contain various materials and records about the largest national women's group in Canada. Although not initially formed as a suffrage organization, the group adopted a pro-suffrage stance in 1910, and following this they became one of the most influential organizations in the Canadian suffrage movement. Because Lady Aberdeen, the founder of NCWC and 
prominent political figure in Canada, declared her public support for suffragism in 1909, all documents of relevance from 1909 to 1919 were consulted. This included official yearbooks, containing annual meeting minutes as well as updates from local chapters and affiliated organizations, as well as official documents released by the association.

\section{Montreal Council of Women}

Also held by LAC, the Montreal Council of Women archives of the local Montreal branch of the NCWC contain reports, scrapbooks, special project initiatives, information about the women's movement in Quebec, and yearbooks published by the group. The Montreal Council of Women (as opposed to other local chapters) archives were consulted for three reasons: 1) two screenings of American suffrage films in Canada took place in Montreal; 2) in the reports of the NCWC the Montreal Council of Women was notably active in issues regarding film; 3 ) these archives were easily retrieved from the LAC, whereas other local branches were located in various cities across the country or have not been preserved.

\section{Montreal Suffrage Association (MSA)/ Fonds de la Montreal Suffrage Association}

The MSA formed in 1913, and was responsible for organizing the screening of Your Girl and Mine. Held by the City of Montreal in Quebec, the archives contain meeting minute records and various committee reports.

4. Fonds de la Ligue des droits de la femme/ League of Women's Rights 
Following the disbandment of the MSA, the Ligue des droits de la femme was formed in 1922 in Montreal. The archives for this organization, found at the City of Montreal archives, contain a 1913 scrapbook of relevance to the study of suffragism in Montreal during the time of the suffrage film screenings.

\section{Flora MacDonald Denison Papers}

Held by the Thomas Fisher Library in Toronto, these papers contain various items such as letters, memos, and scrapbooks relating to the president of the Canadian Suffrage Association (CSA) from 1911-1914, and the Canadian suffrage movement from 18981918. These papers also contain clippings of Denison's suffrage column in the Toronto Sunday World.

\section{Emily and Augusta Stowe-Gullen collection}

Wilfrid Laurier University (WLU) Archives holds a microfilm copy of the Emily Stowe and Augusta Stowe-Gullen Collection, two of the most influential suffragists in the Canadian movement. These archives contain biographical information about these prominent suffragists, as well as pamphlets, newspaper articles, and other documents associated with the CSA and the history of suffragism in Canada.

\section{Media History Digital Library}

The most useful object of analysis within this online library for my research was the collection of Moving Picture World (MPW) issues from 1912-1918. As the Media History Digital Library website describes it, "Moving Picture World was one of the most 
influential trade papers of the early motion picture industry and the period film historians call cinema's "transitional era" (lasting roughly from 1908 to 1917)." Of note is that while $M P W$ is an American publication Canadians were part of the trade publication's intended readership, as Canada screened mostly American films. $M P W$ catered to a North American audience and contained information for, and updates from, Canadian exhibitors, especially in urban centres such as Montreal, Toronto, Calgary, Winnipeg, and Vancouver.

$M P W$ reveals important connections between suffragism and film. It contains articles that deal with issues such as censorship ${ }^{22}$, as well as those that offer descriptions, plot summaries, reviews and exhibition information of mainstream industry suffrage films (most of these were the suffrage comedies discussed in chapter two), films produced by suffragists in conjunction with a studio, and newsreels shown in theatres that covered suffrage events such as parades and pageants (Figs.4\&5). While five issues are missing within this period (as of March 23, 2012 they were still listed on the website as forthcoming), the seventeen available issues still offer a comprehensive snapshot of industry information during the time period that is of interest to me.

Together these archives offer insight into how, and to what extent, suffragists were talking about film during the 1910 s. While a diversity of regions in the archive selection might offer a more pan-Canadian representation of the suffrage movement, I selected archives that seemed the most probable of revealing information about

22 In $M P W$ issues of censorship were not explicitly linked with suffragism. However, given the strong desire of the NCWC to regulate the film industry it is an area fruitful for analysis in this study. 
suffragists and film. The information collected from materials located in these archives offer primary information about a topic that has received little attention in academia. 


\section{7 - Figures}

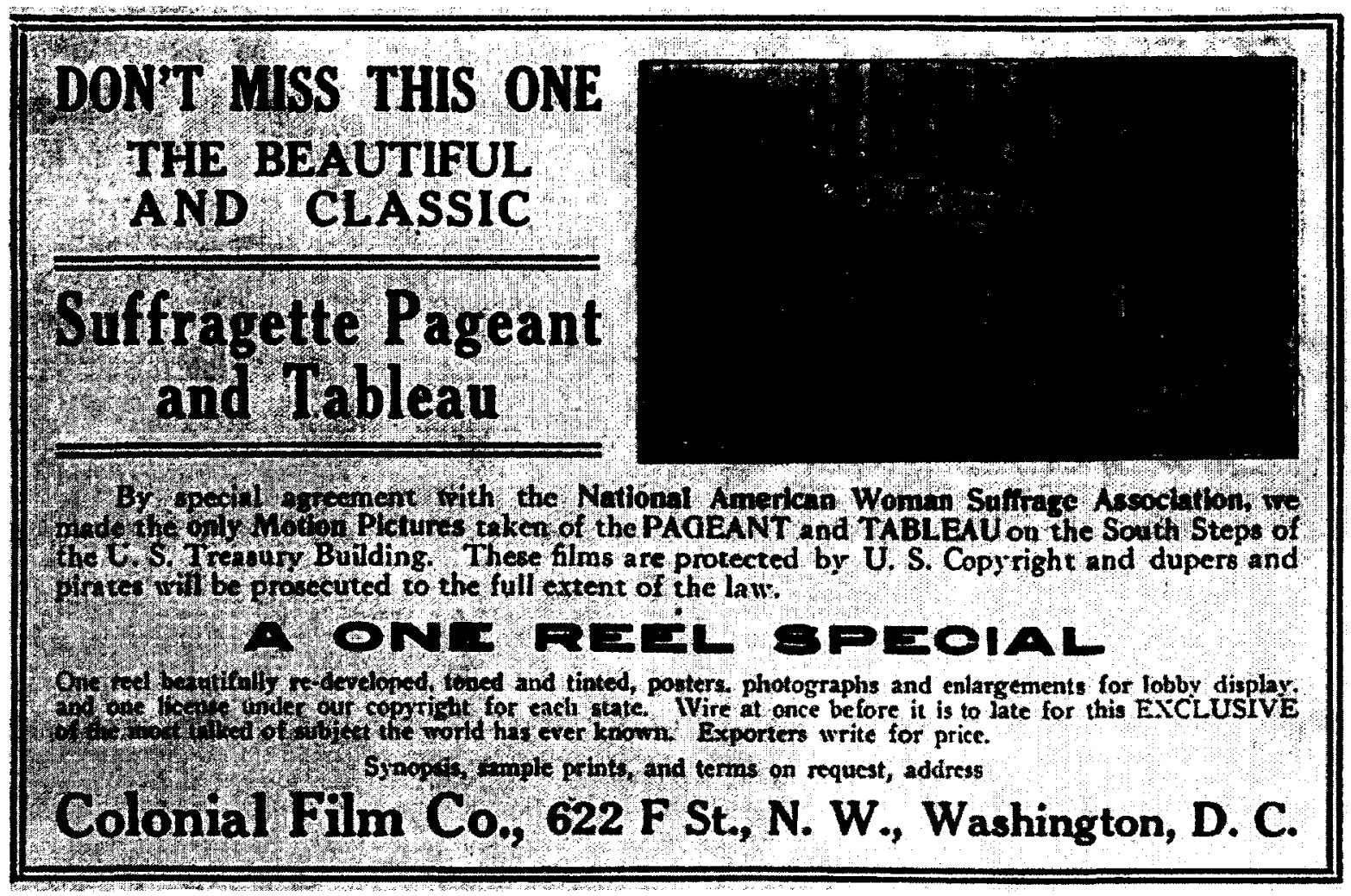

Figure 4: "Suffragette Pageant and Tableau." Colonial Film Co. advertisement from Moving Picture World, April-June, 1912. PDF made available through Media History Digital Library. 


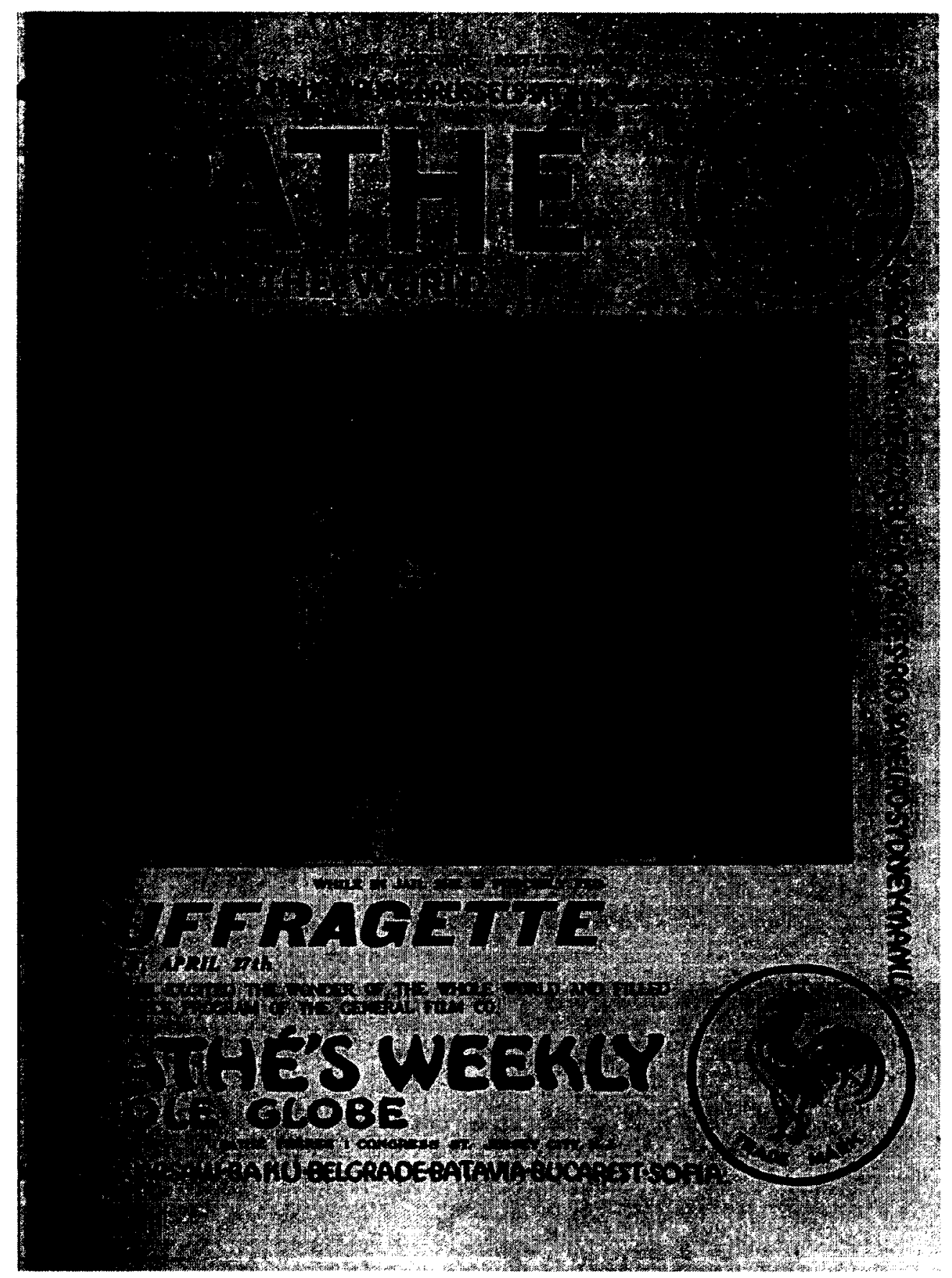

Figure 5: "Suffragette Reels: April 27th." Pathé advertisement from Moving Picture World, April 4, 1914. PDF made available through Media History Digital Library. 


\section{Chapter Four}

\section{The Canadian response: How suffragists addressed film}

The primary goal of this study is to ask if, to what extent, and how Canadian suffragists were talking about film. I aim to understand to what extent they viewed film as a medium in need of regulation, as well as explore how they utilized American alternative media productions for advocacy purposes. Although it was determined that there were no Canadian-produced suffrage films, as there were in the United States, suffragists were concerned with film exhibition during the 1910s.

The National Council of Women of Canada (NCWC) frequently spoke about censorship, educational cinema, and how the council could be involved in the regulation of Canadian film. In this chapter I aim to categorize the range of concerns about film expressed by suffragists, demonstrate the ambiguity of these concerns, and explore how many were grappling with the questions about films' positive and negative impact in society. I will then turn to a descriptive account of what research revealed about the exhibition of American suffrage films in Canada.

\section{1 - The NCWC: The context of discussion}

The majority of discussion about film by Canadian suffragists comes from the National Council of Women of Canada (NCWC). Although not founded as a suffrage organization, between 1909 and 1919 the NCWC was extremely influential in the Canadian suffrage movement. The founder of the association, Lady Aberdeen, publicly declared her support for the enfranchisement of women at the International Council of Women's Fourth Quinquennial Meeting in Toronto in 1909. This had a great influence on 
the growth of and renewed interest in the Canadian suffrage cause (NCWC, 1910). After a long debate at the 1910 Annual Meeting of the NCWC, the council passed a motion, moved on behalf of the Canadian Suffrage Association, "That the National Council of Women of Canada do hereby place itself on record in favour of the enfranchisement of women" (p. 97). When the NCWC is discussed in this chapter, it is in the context that the council supported women getting the vote, and acted as a body that united suffragists from across the country. Although not all members were uniform in their opinions, I refer to NCWC members as suffragists when discussing my results.

The responsibility for examining "moving picture shows" fell to the NCWC's Committee on Objectionable Printed Matter. Initially concerned with exploring pernicious literature, in May 1903 the NCWC expanded the goal of this committee to "include also pernicious plays, and pernicious posters in their work for the protection of the morals of the youth and of our country" (NCWC, 1903). In 1909 the committee's mandate was expanded once again to include film regulation; however, the name of the committee was not changed to reflect the diversity of media they oversaw. In 1918 the Equal Moral Standard and Objectionable Printed Matter committees were combined "owing to overlapping of the work" (NCWC, 1918, p. 173). The suggestion to merge the two committees was made as early as 1913 , but it did not come into effect until five years later. The eventual combination of the Equal Moral Standard and Objectionable Printed Matter committees demonstrates that a moral purity and regulation ideology were underpinning the committee's position on film.

It was in the context of the Committee on Objectionable Printed Matter's reports that film was discussed at annual NCWC meetings. Members of the committee were 
comprised of members from local council's Objectionable Printed Matter committees, and thus the national committee represented women from across the country ${ }^{23}$. Local branches offered reports on the presence and influence of film in their respective cities, as well as their goals for the use of the medium, and how to go about regulating films as well as theatres. The bulk of the committee's work still focused largely on efforts to control objectionable literature, and for periods of time concerns about film were rarely mentioned. In addition to being discussed in reports of committees, several local chapters also spoke directly about film in their annual reports, which were published in the NCWC yearbooks. It is through examining the NCWC yearbooks that contained the annual reports from the Committee on Objectionable Printed Matter and local council annual reports that I address the question of how suffragists viewed the medium of film.

Following the 1909 decision to include the regulation of film in the committee's mandate, the convener of the Committee on Objectionable Printed Matter Mrs. Waycott, who was from Montreal, stated:

Your Convener has thoroughly [looked] into this matter, visiting all the places in Montreal, and has studied the conditions of long range, in other cities, both in Canada and the United States. The conclusion reached by your Convener is that these cheap places of amusement meet a need, and can be used for pleasure profitably, and that all efforts should be made to raise their moral tone and make them safe, and, if possible, educating places for the young, and that any attempt at suppression will be a mistake, as well as difficult. (NCWC, 1909)

${ }^{23}$ As local councils grew in number across the decade they came to represent more diverse areas from across the country. 
This quote from the committee's convener reflects the two main concerns that the committee was grappling with: the space of the movie theatre as a site of amusement and the content of films. Recognizing film's role as an entertainment medium, Mrs. Waycott expressed her desire to use film to educate, as opposed to making attempts to outright suppress it in all forms.

\section{2 - Regulation: Controlling the 'semipublic' spaces of film exhibition}

It was made clear that the Committee on Objectionable Printed Matter was not to only focus on media, but the sites where media were located. At the national meeting in 1917 committee members were reminded of their role: "The work of this National Committee extends to supervision of Moving Picture Houses, Pictures, Picture Postcards, Newspaper and Magazine Advertisements, Literature distributed through the Mails, etc." (p. 124). Regarding film, it was made clear that the Committee on Objectionable Printed Matter was just as responsible for supervising "motion picture houses" as they were for films themselves.

Movie theatres were accessible to the general public - the low cost of admission, which was between five and ten cents in the early 1910s, and inclusion of women patrons did not restrict attendance based on class and gender - but it is best to look at theatres as "semipublic" spaces. This term is used by Ryan (1990) to describe specialized spaces, often built around consumption, which are owned and regulated by individuals. Looking at the movie theatre as a semipublic space allows us to understand how suffragists addressed their concerns and the steps they took to reform these spaces. The NCWC councils not only dealt with the government and aimed to impact official legislation, but 
they worked closely with private theatre owners to address concerns at individual locations. For instance, in 1919 Calgary's report to the Committee on Objectionable Literature made note of the fact that, "Theatre managers are courteous and willing to cooperate with this committee" (NCWC, 1919, p. 141). At the same time that women were trying to ensure that theatres were decent and cleanly places, exhibitors were trying to increase patronage through legitimizing film as an entertainment activity. For instance, a 1911 Moving Picture World article from the Motion Pictures Exhibitors League discussed the desire of exhibitors to work with censors in a "campaign against immorality" (MPW, Jan.- March 1912, p. 569). The president of the League argued that the exhibition of "low grade" films "have a tendency to lower the standard not only of houses in which they are shown, but of the motion picture world in general" (MPW, Jan.March 1912, p. 569). Similar to the Motion Pictures Exhibitors League and censors in the United States, NCWC local councils and theatre owners had a mutually beneficial relationship.

\section{i. Upkeep of the 'moving picture house'}

In 1910, the Local Council of Women of Toronto, in partnership with the Committee on Laws for the Better Protection of Women and Children, completed a thorough investigation of the thirty-four moving picture theatres in the city. On May 4, each theatre was visited by one or more of these women, who took note of the theatres themselves, including "the character and behaviour of the audiences, proportionate number of children present, lighting, ventilation, means of exit in case of fire - in fact, all the attendant conditions" (NCWC, 1910, p. 38). Noting that they visited the theatres of 
Toronto because the executive committee was somewhat divided on film - members of the council expressed "conflicting opinions" in a previous meeting - the committee reported that in the majority of cases the result was "most gratifying." In terms of the physical buildings, bad ventilation in some of them was the only issue reported.

Suffragists believed that airflow within the theatre was important, though no explanation was given as to why. The NCWC stated, that "proper ventilation of all moving picture theatres should be insisted upon" (NCWC, 1917, p. 89).

A key concern expressed by local councils about the space of the theatre was cleanliness, as theatres were sometimes perceived to be a public health problem (NCWC, 1909). The 1909 Port Andrews local council report brings attention to small theatres that were not kept "cleanly," and references a place that was "disgusting" and "unsanitary." The local council concluded that some of these small theatres in Port Andrews were a "menace to public health", and that a regular inspection from a health officer was necessary. These concerns about public health and poor sanitation in theatres are consistent with the general belief that women reformers had at this time regarding their duty to ensure the cleanliness and overall health of cities. In the early twentieth century the traditional notion of "woman as protector-of-the-home" was expanded to include "woman as protector-of-the-city" and many women engaged in "municipal housekeeping" to ensure the general upkeep of public spaces (Mackintosh, 2005).

Overseeing the activities of movie theatres - either by taking on the responsibility themselves or by advocating for others to do so - varied by local branch. In addition to working with local theatre owners, as described above, local councils often formed other partnerships. For instance in 1909, the four local councils that address film in their 
reports all expressed different solutions for overseeing the operations and upkeep of theatres. The Montreal Council of Women wanted to keep people away from "poor theatres and moving picture shows" completely and worked with the Montreal Ladies Morning Musical Club, the Women's Art Society and the Canadian Handicrafts Guild to provide local music and artistic entertainment around the city, which they thought would discourage film attendance. Although the report does not explicitly state what the particular "instance" was, the Port Andrew, Ontario branch asked the police to intervene, and notes that the police department expressed the desire to use their power "to keep small decent theatres under [their] jurisdiction" (NCWC, 1909). The Local Council of Women of Kingston wanted to maintain a Vigilance Committee (NCWC, 1909). While the Local Council of Women of Halifax did not explicitly state how they planed to oversee movie theatres, they suggested women watch films because of their popularity with children.

With the expansion of theatres across the country at this time it was becoming difficult for councils to oversee the activities of all of them, and some local groups took measures to reduce the number of theatres in operation. In 1910, the Montreal Council of Women was very active in establishing specific techniques to "shut up the smaller [movie theatres], all too numerous, and make the surveillance of comparatively few much easier" (NCWC, 1910, p. 39). They helped to ensure a newly implemented bylaw - which required a $\$ 500$ operating license for theatre owners - was upheld, as they believed smaller theatres did not have the means to pay such fees. The council further mentioned a campaign they initiated by working with a local newspaper to report theatres that weren't following fire code regulations and had "unhygienic condition[s]" (NCWC, 1910, p. 39). 
This publicity garnered by the Montreal Council of Women and the newspaper resulted in a "thorough investigation ... and active reforms were effected." The convener of the Committee on Objectionable Printed Matter (who was from Montreal) worked with the city's Morality Department to "assist in several ways" (NCWC, 1910, p. 39). Two years later the Montreal representative of the Committee on Objectionable Printed Matter noted that the local council continued to show an interest in the city's fifty-five places where movies were shown. In 1912, the sub-committee of the Reformation Committee of the Local Council that visited the Montreal theatres, "reports a distinct improvement in the excellence and character of the subjects" (NWCW, 1912). In Montreal, as well as other cities, it seemed that women were having an impact on the semipublic space of the theatre.

\section{ii. $\quad$ The audience}

A key reason why local councils expressed a desire to regulate theatres was because they believed particular aspects of how theatres were controlled influenced the behaviour of audiences. Lighting, for instance, was a major concern in Montreal. In 1912, the council noted that they requested theatre owners to keep their establishments well lit, otherwise there were times these halls were used as "meeting places, at which improper appointments were conveniently made" (NCWC, 1912). Their belief was that darkness "is a menace to morals in this and it should be prohibited" (NCWC, 1913, p. 82). There was a general concern - at least from reformers - that in the darkness there was a likelihood of "romantic encounters", which made women vulnerable to promiscuous behaviour (Stamp, 2000). 
The public nature of movie theatres, as well as other sites of amusement such as dance halls, shaped heterosexual dating culture at this time. They offered a more private and anonymous space for couples on dates, and anonymous people could meet in these spaces with some degree of privacy (Stamp, 2000). There was even the belief that the sole purpose of commercial amusements was heterosexual interaction which spawned "sexual delinquency", as such spaces "inflame[d] 'abnormal desires"” (Strange, 1995, p. 128). As a result these venues were "targeted as prime sites of urban moral regulation" (Strange, 1995, p. 117). In that context, it is not surprising that the Montreal Council of Women asked for more light in theatres, as they surely believed that it would decrease encounters, presumably of a sexual nature, between patrons.

Even if the physical conditions of the building were in order, controlling the audience was still an issue. The Equal Moral Standard and Objectionable Printed Matter committees discussed audience supervision at great length, with most of the concern focused on youth, who were frequently attending movies. The view expressed by the convener of the Committee on Equal Moral Standard and Prevention of Traffic in Women was that children attending movies unsupervised was problematic, and that NCWC should insist upon "proper chaperone of the young" (NCWC, 1917, p. 89). Youth played an important role in the overall reform movement. Suffragists were working to "improve" the next generation through children, and thus they took great care in ensuring their "physical and moral health" (Bacchi, 1983, p. 91).

At the local level there were different approaches for how to best supervise children. In cities such as Vancouver there was a woman attendant in the theatre (NCWC, 1919). In 1919, Ontario passed an amendment to the Theatre Act, which required matrons 
to be in the moving picture house for any performances attended by children. Parental supervision was another solution. New Westminster had a policy that children were requested to leave the theatre by $8: 30$ p.m. if they were not with a parent or guardian (NCWC, 1918). The Local Council of St. Thomas and Elgin County ensured the enforcement of a by-law that prohibited children under the age of sixteen from attending movies if they were unaccompanied (NCWC, 1917). Perhaps Port Arthur was the most extreme; children were only allowed into theatres if they were supervised, if they were not, police prevented them from attending shows (NCWC, 1918).

Simply banning youth was only one way to solve this problem, and some theatres began arranging special exhibitions - most often matinees - for younger viewers. In New Westminster Friday and Saturday exhibitions were arranged specially for children, and in Toronto a leading theatre in the city began screening "fairy stories" on Saturday mornings (NCWC, 1918). In Vancouver, the local women's council worked in conjunction with theatre owners to start screening children's films for two hours on Saturday afternoons. Women from the council asked four of the "leading picture house managers" to help with this initiative, and reported that exhibitors were "very willing to co-operate." The council members visited various theatres in the city and chose the films "most suitable" for the children's matinee. Key in this Vancouver arrangement was that children would only be offered half-price admission during these matinees (the special rate previously applied anytime), as the local councils were "hoping that the effect would be to prevent [children's] attendance in the evening" (NCWC, 1918, p. 96).

By the end of the decade the special children's matinees were a prominent part of many theatres' programming, and even became a reason why local councils advocated 
for film in particular cases. In Montreal the local council implemented children's screenings at the Imperial Theatre, where one or more of the committee members attended each screening (NCWC, 1919). Because the screenings were extremely popular - the average attendance of children at ordinary shows was estimated at twenty-five daily, and there were 600 to 1,000 at the special children's performances - the committee was strongly opposed to a new bill that would have banned all children from attending moving picture shows. The bill, which had recently been introduced by the Provincial Treasurer before the Legislative Assembly in the Province of Quebec, had the intention of "forbidding children's attendance at the moving picture shows, even when accompanied by an adult." The convener of the Committee of Objectionable Printed Matter wrote to the Provincial Treasurer and the Premier of the Province, and she reported to the committee that the suggestions she put forward were incorporated into the bill. "As amended, the Bill now provides for such special entertainments for children, as this committee has initiated," stated the Montreal report (NCWC, 1919, p. 143).

Overall, the Committee of Objectionable Printed Matter considered "moving picture entertainments for children" a huge success, and in 1919 the convener declared that they had become a "nation wide movement" (NCWC, 19.19). Yet, there were still obstacles that the committee was faced with, mainly the lack of films that they deemed appropriate to screen to children. The solution proposed by the convener was not to create films themselves, but instead to turn to the "principal film producers of Great Britain and the United States, to place before them the urgent necessity for the production of films suitable for children, instructive, amusing and patriotic, the educational value of which could hardly be measured" (NCWC, 1919, p. 140). 


\section{3 - Regulation: Media effects}

The content of film is something that the NCWC struggled with over the years. Filmgoing was recognized as an increasingly popular leisure activity, and it was perceived to have great influence. The convener of the Committee on Objectionable Printed Matter even believed that "many people are getting their ideas more from the "Movie" than from reading" (NCWC, 1913, p. 89). Concerns were expressed about the potential danger of film and its ability to corrupt, but the NCWC also saw the potential of film and celebrated the effects that educational cinema could have on audiences. What is pivotal in how film was discussed by the NCWC - either as a force of harm or education - was a belief in media effects, or the film's ability to directly influence the audience. As a new and visual medium, the council thought that media effects were heightened because of the "powerful effect which may be produced on the mind by scenes graphically presented to the eye" (NCWC, 1910, p. 50).

One of the beliefs held at the time was that because of the quality of films being produced, technological advances had a damaging effect on culture. In the words of the Local Council of Women of Kingston, "Objectionable moving pictures remind us that the inventions of this age are constantly being pressed into the service of evil" (NCWC, 1909 , p. xiii). While other local councils were not as overt in the belief that film was being used as a "service of evil", the reports of the NCWC often highlighted similar opinions about film as a negative force in society. The equipment used by projectionists was a focus of concern for some, as it was thought they could damage one's physical body. The convener of the Committee on Equal Moral Standard and Prevention of Traffic in Women spoke against the "cheap machines with the "flicker," so harmful to the eye" 
(NCWC, 1917, p. 89). She suggested that the equipment should be standardized, and that "harmful" projectors should not be allowed. In both of these comments the technology used to create and screen films was seen as a key factor in why the medium was having damaging effects.

A lot of discussion in the committee of Objectionable Printed Material addressed media effects, going further than just highlighting the perceived harm caused by moving pictures to how this was translating to actions. For instance, after a Board of Theatrical Censors was appointed in Quebec, the Montreal Council of Women referenced a provincial censor who drew a direct correlation between petty thefts committed by boys and film, stating that the thefts were "caused" by the attraction to the movies. The belief was that the re-presentation of media gave these vulnerable children ideas about how to commit crimes that they would not have known how to do before. The censor also pointed out that youth, in particular, were effected by movies in a way that grownups were not.

I also know that the greatest number of petty thefts committed by boys are caused by the attraction of the 'Movies' and in many instances the way the robbery is carried on is only a second edition of some clever robbery as shown by the film. Even with many moving pictures not quite immoral for the grown, there is an incentive to immorality, or a suggestion too strong for the adolescent. (NCWC, 1913, p. 82)

The NCWC had a special concern for "children of tender years", as they were presumed to be more vulnerable to the "powerful effects" of film (NCWC, 1917). 
In this context, the NCWC developed specific approaches for how to best regulate the content of the medium and many local councils became active in this process. One of the initial steps taken by local councils was to get a general feel for the types of films that were being screened in Canadian theatres. As part of the same 1910 Toronto investigation that observed the general quality of the space of the theatre, these women also noted the quality of the films. Although observing that some sensational films, which included scenes of violence and crime, were shown, "In the majority of cases the shows were beyond reproach, many of the pictures being really beautiful and instructive" (NCWC, 1910, p. 38). The report makes clear that "several pictures were vulgar, but in not one case was anything of an obscene nature reported" (NCWC, 1910, p. 38). The report of the Local Council of Women of Toronto noted that they were "very agreeably surprised both as to the character of the entertainments and as to the conduct of the audiences" (NCWC, 1910, p. ii).

Although the Local Council of Women of Toronto observed that no "obscene" films were screened, they still took action to ensure that all films shown were of the upmost quality, and they expressed a desire for the NCWC to establish some form of national regulation system. Following the report of the Local Council of Women of Toronto, a resolution was passed that stated:

In view of the great number of persons of all ages who frequent theatres and shows, and of the powerful effect which may be produced on the mind by scenes graphically presented to the eye, and also of the harmful character of many dramas and many shows: Be it resolved, That the National Council of Women urge upon the Local Councils the importance of asking their respective municipal 
authorities to institute public censorship regulating all such entertainments. (NCWC, 1910, p. 50)

The reality that few theatres were actually showing content that the local council disapproved of was not the issue. The "powerful effect" the medium was perceived to have resulted in the NCWC taking attempts to regulate film; the possibility of obscene or immoral content was enough.

Rhetoric regarding morality and film was found in places other than suffrage committees. Issues relating to censorship were often discussed in Moving Picture World $(M P W)$. A $1912 M P W$ article makes a plea to the "license-paying exhibitor", the "lover of the clean picture", and "the moral and upright citizen everywhere" to advocate for changes in film exhibition and production conditions that "permit such an evil" (MPW, April-June 1912, p. 1105). Appearing under the headline "Degrading the Pictures", the author $^{24}$ writes,

No protest can be too vehement, the moving picture is too valuable to be degraded; its mission is to uplift, educate and amuse. It must not be part of anything abominable to the highest public good; nether must it be hurled into those depths the precipitous sides of which are made slippery with the slime of slang. Last and most important, the pictures must not be used as an attraction, a bait, an allurement, a trick or a device to cheat the law, degrade humanity and lead children into sin and vice. (MPW, April-June 1912, p. 1105)

${ }^{24}$ The article is simply attributed to "W. H. J." A different article in the same issue of Moving Picture World mentions an MPW staff member Rev. W. H. Jackson. 
The author of this article, like members of the NCWC, did not see film as inherently negative, but that in its current manifestation the content of pictures could be damaging to society. Given this general belief there were two ways that the NCWC sought to address this issue. They championed stricter censorship of motion pictures, advocating that women should sit on local censorship boards. Secondly, the NCWC advocated for the exhibition of more educational films because in their view, "Education is certainly dispensed by Moving Pictures" (NCWC, 1915, p. 245).

\section{i. Censorship: Women as censors}

One of the goals of the NCWC was to have women appointed to positions where they could influence the content of the films. Especially active in ensuring that this came into effect was the Local Council of Women of Toronto. At a meeting of the executive committee in 1912, they put forward the motion, "That the National Council of Women do memorialize the Ontario Government asking that a woman be appointed on the Board of Censors of Vaudeville Burlesque plays and moving pictures" (NCWC, 1912). The motion was passed in the following year. Toronto was not the only local chapter concerned with regulating the content of film and having women sit on censor boards. At a meeting in October 1914, the Local Council of Women of Ottawa also made clear their stance on women's involvement in regulation, while still noting the potential positives of film:

Whereas, realizing the vast educational and artistic possibilities of the Moving Picture Shows, but at the same time deploring the undoubted evil effect of many films now shown, the National Council of Women be requested to memorialize 
the Ontario Legislature, asking that one or more women be appointed members of the Ontario Board of Censors. (NCWC, 1914a)

This motion was approved, however, it does not appear that any immediate action was taken. In 1915, once again the Local Council of Women of Ottawa presented a similar motion, rephrased slightly (NCWC, 1915).

By 1918 there were reported results in this area. The convener noted that different cities were taking different approaches, and that "in some cases a woman censor has been appointed, in other cases the Local Committee has been invited to censor special films for children, and nearly all the reports, sent in this year, refer to efforts being made towards this end" (NCWC, 1918, p. 96). While few committees, such as the Committee on Objectionable Printed Matter, were active during the war years, by the end of the decade there was a renewed enthusiasm for providing wholesome entertainment throughout the country and for increasing the number of women in film censorship positions. Several urban branches in cities such as Montreal and Ottawa put forward bills to address their concerns in a formal way. In 1919 the convener of the Committee on Objectionable Printed Matter recommended that members of the committee across the country work to establish censor boards that included women (NCWC, 1919). By 1919, many local councils had successfully advocated to have women censors appointed at the provincial level, such as in Alberta and Winnipeg (NCWC, 1919). In Halifax four women sat with the managers of local theatres and the province's censor on the Board of the Social Service Bureau (NCWC, 1917).

That women were experiencing success in censorship involvement is not surprising. The fact that women were active in social reform movements was generally 
accepted by Canadians, as it tended to perpetuate the view that women's place was in the home (Burt, Code \& Dorney, 1988). Actions relating to civic housekeeping, such as regulating movies, were simply one way that suffragists were enacting their roles as mothers of the nation. The general belief of reform suffragists was that their roles as mothers gave them an obligation to preserve Canada through the moral upkeep of the nation (Errington, 1998). Maternal qualities, that all women were presumed to have, led the NCWC to believe that women would make excellent censors. They would know what films to approve for exhibition, if specific scenes needed to be removed, and the general type of content that audiences should be exposed to. The Montreal Council of Women was explicit in their belief that the inherent features of women would translate well to film regulation. After concluding that the censorship of films was necessary they declared that "women were undoubtedly qualified" for censor positions (NCWC, 1919, p. 143). Convener of the Citizenship Committee Augusta Stowe-Gullen also shared in this belief. After noting that the Citizenship Committee had been advocating for an Official Board of Censors for moving pictures, she declared that "half of this board should be women and the basis of appointment worth and capacity, and not political" (NCWC, 1919, p. 120).

Though the motions that were passed did not have any binding power to change legislation to ensure that women were appointed to film regulation bodies, the reported success of the NCWC is significant. The channels that these women worked through are also noteworthy. Women collaborated with theatre owners to ensure the films that were screened were deemed appropriate, but they also petitioned provincial and local governments to have women appointed to censorship positions. Having an interest group - such as the NCWC - work with the state to influence legislation was common at this 
time, as most governments didn't yet have specific departments to deal with issues such as regulation (Valverde, 1991).

Ironically, two films that Canadian suffrage associations actively supported were subject to censorship, which is noteworthy because censorship was something that the NCWC generally supported. Chicago censors removed a fight scene before the suffrage film Your Girl and Mine was screened (MPW, Oct. 3, 1914). McCormick, the lead producer of the film, condemned this decision. The fight scene, which "showed a woman struggling with a man in the interest of her right" was physically removed from the reel, and McCormick declared that "Censorship as an institution is medieval and undemocratic" (MPW, Oct. 3, 1914, p. 621). To hear a suffragist speak out against censorship is quite jarring given that prominent suffragists, such as Jane Addams, had been so vocally in favour of film regulation less than five years prior to this.

Another censorship controversy surrounding a film that screened in Canada involved the use of film for public education. The NCWC promoted the American film (as well as the play) Damaged Goods, which focused on venereal disease. Speaking about the film in particular, the report from Toronto to the Committee of Objectionable Printed Matter explained that the Local Council of Women of Toronto had endorsed the film after it had been shown to a "body of leading citizens" two years earlier (NCWC, 1919, p. 98). Following this screening, the film was used by "Special Order-in-Council for military camps." The Ontario and other provincial censors had rejected the film version for exhibition, and the play was also banned.

In 1918, the Toronto local council worked with the Academy of Medicine to remove the ban on both the play and film (NCWC, 1918). The NCWC passed a motion to 
petition provincial governments to no longer censor the film and play, noting their educational values. The convener of the Committee of Objectionable Printed Matter believed in the educational aspects that the film had, referencing a medical military officer who said that both the play and film Damaged Goods "should be shown throughout the country, and if necessary should be subsidized by the Government for their educational value in certain conditions" (NCWC, 1918, p. 96). Although the NCWC yearbooks contain no more information about if the ban was lifted, Dean's (1981) research found that following an appeal Damaged Goods was screened, but only those 16 or older were permitted to see the film. Promoting educational films, such as Damaged Goods, was the second approach taken by the NCWC to deal with media effects concerns.

\section{ii. Using film for education}

While expressing a desire to regulate film, the NCWC sought to improve the overall "quality of it" instead of simply banning particular films. As the report of the Committee on Objectionable Printed Matter stated in 1911:

The effort to direct entertainment along educational lines, not too obviously emphasized, is becoming a striking factor in all kinds of reform. Last year we noted the partial suppression of the comic pictures in the most reputable newspapers, but as total suppression seems impossible of achievement, the comic supplement, like the moving picture show, must be made to improve and not demoralize. (NCWC, 1911, p. 58) 
This decision to "improve" and to avoid suppressing or banning media - such as the comic book and the "moving picture show" - was typical in the moral reform movement. Valverde (1991) points out that while the movement was obviously repressive in some ways, "regulation" is a more appropriate word to describe the movement's goals and operation. Valverde explains that regulation is more concerned with "preserving and shaping something and not merely suppressing it" (p. 33). Suffragists thought that if they appropriately regulated the types of films that were being exhibited, film could be used as a tool of education, especially in the cities.

For instance, in 1912, the convener of the Committee on Objectionable Printed Matter referenced the recorder of the city of Montreal Robert Stanley Weir who stated: I have no doubt that some moving picture shows now in existence in this city could rightly be termed as light. They are not all the same kind and should not be condemned en bloc. Instead of being a 'school for crime' ... they could be made a power for good. With an efficient censorship they could be made a means of education for young and old. Scenes of history, past and present, should be presented, giving names and dates, and the community at large would be benefitted. (NCWC, 1912a)

Importantly, Weir, as well as the NCWC, believed that instead of screening films that had the potential to corrupt, theatres should exhibit those with an educational value.

The 1919 Equal Moral Standards Committee Report noted that there was a need for "creating a demand for the proper kind of film." As the report states, it was recognized that, "The "Movie" is here to stay, and we should bestir ourselves to make it an asset, not a liability, as a social factor" (NWCW, 1919, p. 148). The Committee on 
Objectionable Printed Matter Committee addressed the issue most comprehensively and stated:

By thus taking full advantage of the appeal which moving pictures make to the general public, and at the same time protecting children from all adverse influences, a great deal of service might be rendered in the community in general, and children in particular. The possibilities of moving pictures are vast, and it is predicted that they will become, when the present objectionable features are eliminated, the most potent of all educational factors. This cannot be brought about all at once. Awakened public appreciation of what the moving picture might be, compared to what it is, will rend greatly towards paving the road to reform. (NCWC, 1919, p. 140)

Fulfilling their roles as maternal feminists, these women viewed regulating and promoting quality film as way to educate the nation.

The issues covered in educational films spanned a variety of subjects. In 1913 the NCWC's Committee on Public Health explained that the fly had been exterminated in many cities and that a key part of the extermination campaign's awareness strategy relied on "having fly films in the moving picture houses" (NCWC, 1913, p. 107). The Local Council of Women of Ottawa cited the recent Ontario Health exhibit, "which is now a moving picture show", that came to Ottawa and provided "free entertainment" in the Y.M.C.A and other halls (NCWC, 1915, p. 94). Seeing films employed in effective ways, suffragists desired the screening of films outside of the movie theatre context. In Montreal, libraries began holding "special moving picture entertainments for children" on Saturday mornings, both at a local theatre and library branches (NCWC, 1919). The 
Local Council of Women of Toronto suggested that film should be used both for educational purposes in day and Sunday schools, as "the moral tone of the picture shows is improved and they are becoming less crude" (NCWC, 1913).

At this point there was still no suggestion that suffragists should use film to promote their own political cause. A somewhat vague description of how the medium of film could be used in a positive way is found in an update from the Montreal Council of Women in 1913, when the council reported a popular public event that took place in the city:

A splendid use of moving picture was carried out during the past summer evenings by giving free representations in the different city parks. Many thousands of adults and children were present on these occasions and much enjoyment was evidenced. It is the hope of all interested that this initiative may be followed more fully in the approaching summer season. (NCWC, 1913, p. 82) The 1913 NCWC yearbook notes that following the report of the Committee on Objectionable Printed Matter, the committee "discussed the educative value" of film. The details of the discussion are not recorded, but the yearbook notes that a member of the NCWC "spoke of the possibility of the Playground Associations making use of moving pictures" in their publicity work (NCWC, 1913).

While it is not known if the focus of their presentations was on suffrage, there are records of speakers brought in by local Canadian women's groups who used moving pictures as part of their lectures. In their 1912 annual report, the Montreal Council of Women described a public meeting held in November, where the organizer of a Child Welfare Exhibit "gave an address illustrated by moving pictures" (NCWC, 1912a). That 
same year the Local Council of Women of St. John highlighted that in March Miss Katherine Campbell, of Montreal, who represented the Handicrafts Guild of Canada gave an "illustrated lecture and exhibit." In addition to noting that the presentation was "interesting and enjoyable" the report states, "The lantern slides alone were a revelation to many" (NCWC, 1912a, p. xii). In the 1913 annual report of the Montreal Council of Women, they highlighted that their local council was one of the four large associations involved in a public event that utilized film, and that the council paid for one of the screens (NCWC, 1913). By the mid-1910s various committees of the NCWC saw the value of using film for publicity purposes. Yet, no recorded discussions took place to discuss how, or if, film should be used to bring attention to the suffrage cause.

In an address from the Citizenship Committee in 1919 Dr. Augusta-Stowe Gullen established Canada's reliance on importing films. She critiques this feature of the industry stating, "Neither is there any reason why Canada should not produce films of English and Canadian events, instead of almost, if not entirely, using American films" (NCWC, 1919, p. 120). While Stowe-Gullen might have expressed a desire for Canadianmade films, the country's production conditions, mostly the economic challenges that arise from a geographically fragmented country, were not conducive to film production. Canadians relied on a variety of different films from the United States, including alternative media.

\section{4 - Cinematic advocacy: Alternative media raising funds for the war effort}

The Montreal Suffrage Association (MSA) - which was formed out of the Montreal Council of Women in 1913 to specifically address suffrage issues - was 
interested, from its inception, in advancing the suffrage cause to the public through creative, but still educational, means. The president of the MSA was clear that the organization would not employ the same tactics as militant suffragists in England, and that they would focus on education. Quoted in an April 25, 1913 article from the Montreal Gazette Derick stated, "The work of the society some time at least will be largely educative. It will help in those political and social reforms that recognize women as worthy members of the state. It will teach by lectures, by the distribution of literature and by articles in the daily press" (Ligue des droits de la femme, 1913a). From the first meeting of the executive committee on May 20,1913, a speaker series was proposed and there was a desire for a touring theatre company to include suffrage plays in their next visit to Montreal (MSA, 1914). Other suffragists recognized the efforts of the MSA, and noted that the MSA did a lot to "open the eyes of the public to the merits and justice of women suffrage” (Stowe, “A Synopsis of Woman Suffrage in Canada").

Canadian suffragists did not express views that film was a useful tool for advocacy, which is interesting given their intention to take an "educational" approach when promoting suffrage. The 1909 report of the Canadian Suffrage Association (CSA) stated, "The [suffrage] work throughout Canada has been carried on along educational lines. Lectures, debates, writing magazine articles, supplying books for public libraries, are among the most popular means of propaganda" (NCWC 1909, p. xxiii). Yet, while they highlighted the propaganda work employed throughout the nation, the NCWC was silent on using film as a form of propaganda. The reports of the CSA included in the NCWC yearbooks often discussed what they were doing to remain active, and throughout 
the 1910 s there were no mentions of film being part of their recruitment or publicity strategy.

The focus was mostly on the newspaper medium, as the CSA discussed how suffragists wrote for newspapers as a way to promote their political message. For instance, the 1911-1914 president of the CSA Flora MacDonald Denison had a weekly column in the Toronto Sunday World, the CSA circulated the various suffrage associations' literature throughout the country, and suffragists actively participated in events that they thought would garner publicity in the press (NCWC, 1913). A special strategy for Canadians was linking themselves to suffrage activities taking place in the United States, such as the Great Suffrage parade in Washington on March 5, 1913. Denison and other Canadian delegates attended the parade and Canadian newspapers reported on the event (NCWC, 1913).

Public lectures were another form of advocacy that Canadian suffragists championed. Especially in larger cities, local NCWC councils and the CSA brought prominent British and American suffragists to speak. The Montreal Council of Women (prior to the MSA forming out of this council) in particular, seemed focused on this publicity technique. For instance, in the 1910 annual reports from the various local branches of the NCWC, the Montreal branch notes two events where they had American suffragists - Mrs. Philip Snowdon and Miss Sadie Anderson - come and speak. Given the urban location of the MSA and their particular publicity strategies it is not surprising that they came to exhibit American suffrage films, though my research did not offer insight into the means they took to do so. 
Montreal and Toronto were the only Canadian cities where I found evidence of suffrage film exhibition. I have no reason to believe Votes for Women, Your Girl and Mine, or any of the other four American suffrage films were screened elsewhere in Canada, although it is possible. As not all regions were active in the NCWC, especially Central and Western provinces in the early part of the 1910s, it is conceivable that other cities exhibited suffrage films, which was then never reported to the NCWC. While a local newspaper article provides evidence of the Montreal screening of Votes for Women, it was not recorded in the NCWC reports. Likewise, the planned Toronto exhibition of Your Girl and Mine was not documented in the NCWC yearbooks. This is clearly reflective of record keeping in the period, which makes it difficult to paint a complete picture of suffrage film exhibition.

Information obtained in the NCWC, Montreal Council of Women, MSA and Fonds de la Ligue des droits de la femme archives, as well as Moving Picture World articles brings to light new information about the known Montreal screenings of Votes for Women and Your Girl and Mine. Details about the Montreal screenings have only ever been mentioned in passing (Cleverdon, 1974, Shore, forthcoming 2013; Sloan, 1988), not receiving more than a sentence of attention. Two articles appearing in $M P W$ also suggest that Your Girl and Mine was exhibited in Toronto, a screening that has not yet been documented in literature.

Production information about Votes for Women and Your Girl and Mine has been discussed by scholars such as Shore (forthcoming 2013), Sloan (1998) and Stamp (2000). These scholars often refer to $M P W$ articles, and in some instances I use the same source as they did. By doing this I aim to provide contextual information about the films 
screened in Canada, and to further demonstrate why suffrage films should be considered alternative media, as discussed in chapter two.

i. Screening: Votes for Women - Montreal, June, 1912

A June 22 article appearing in the women's section of the Montreal Daily Star discusses the "silent motion picture play" starring Jane Addams, Dr. Anna Howard Shaw, and other prominent suffragists. The article states that the U.S. National Board of Censorship had the idea to make the film, and that although suffragists were initially resistant to the idea suffrage leaders soon saw the value of producing a film.

"Members of the board came to us," Mrs. [Mary Ware] Dennett, [corresponding and executive secretary of the National Suffrage League] went on to explain, "and suggested that we produce a motion-picture play about suffrage, along the lines of other educational motion-picture plays. The idea didn't appeal to us particularly, because it has been our solemn duty to read through many suffrage plays that were sad stuff; but after we were shown some of the educational films we were enthusiastic." (Montreal Daily Star, June 22, 1912).

There is some discrepancy about who exactly approached the suffragists to make a film, as a 1912 article about the production of Votes for Women appearing in Moving Picture World states that executives from Reliance (one of the largest independent film production companies at the time) convinced suffragists of the benefits of using film for their cause (MPW, April-June 1912, p. 617). While the facts surrounding the source of the filmmaking proposition are not clear, the sentiment about suffragists being convinced to utilize the new medium that they were previously critical of is consistent. As the $M P W$ 
article said about suffragists getting involved in filmmaking, "An idea which at first seemed utopian to their dignity and ideals, upon close scrutiny was found to be the most powerful agency obtainable for the furtherance of their cause" (MPW, April-June 1912, p. 617). Ads appearing in this same issue of $M P W$ celebrated Votes for Women and noted that it "has the support of every suffrage organization in the country" (p. 1094).

The film review of Votes for Women states that $M P W$ had previously argued that it would be valuable for suffrage organizations to make films. Additionally it states that it was not until the Reliance Company made Votes for Women that combining suffragism and film was "made a big thing" (MPW, April-June 1912, p. 811). The review suggests that the film served two purposes: it represented an authentic portrayal of the suffrage cause, and it allowed prominent suffragists to become "personally known to thousands of women all over the world who already know them by name." These two purposes reveal key features of alternative media. Representing suffragists in an "authentic way" made suffrage films a form of radical content because at this time mainstream studio productions were comedies that mocked the suffrage cause (Norden, 1986; Sloan, 1981). This authentic portrayal also allowed suffragists to be in control of their own image and message, giving them a cinematic "voice." Secondly, that viewers became aware of suffragists through their re-presentation on film highlights the importance of specific visual features of the medium.

Following the plot summary of the film, the $M P W$ review of Votes for Women ends on a positive note, and congratulates the suffragists for their efforts. "A word of commendation should be said concerning the work of the suffragist ladies in the picture. They are not at all amateurish, as one might expect, but to the contrary they play their 
parts in a thoroughly natural manner and entirely to their credit" (MPW, April-June 1912, p. 811). Non-professionals suffragists were the central creative talent in Votes for Women, an alternative way to organize cultural production. For this, their efforts were well received by the $M P W$ author.

American suffragists, such as Inez Milholland Boissevain (Fig.6), celebrated the technology of film, and the potential of it. The lawyer-suffragist who appeared in Votes for Women is quoted in a $M P W$ article:

What an unlimited range of possibilities and what enormous potentials does this great modern development, the motion picture, possess! It occurs to me what a splendid medium it is for breaking down race barriers, for instance, and for the production of vast humanizing influence. The magic camera can be brought into play in any and every obscurest corner of the earth and reproduce the various humans as they live and are. And when they appear on the screen before our eyes we are certain to find that in the last analysis we are all alike - and a bond of inter-human fellowship is at once affected. (MPW, July 1914, p. 947) Inez Milholland Boissevain praised the potential of film, noting how the technology itself creates a particular type of product that could be used to humanize the subjects on screen. Like Canadian suffragists, Inez Milholland Boissevain believed that specific technological features worked to create a particular type of alternative media that influenced audiences in a particular ways that other media do not.

As the first nationally distributed suffrage film, Votes for Women was seen across the United States. There is little documented about the Canadian exhibition of Votes for Women, which was shown in Montreal in 1912. A June 22 article appearing in the 
women's section of the Montreal Daily Star talks about the film starring Jane Addams, Dr. Anna Howard Shaw, and other prominent suffragists, but offers no details about where the film was to be shown, or information about tickets. According to the Star article, Votes for Women was to be released in Montreal on June 26. (Fig.7)

\section{ii. $\quad$ Screenings: Your Girl and Mine-Montreal and Toronto, 1914}

Although Votes for Women was the first suffragist film that $M P W$ celebrated, a similar sentiment was expressed with the production of Your Girl and Mine two years later. The lead to the review of Your Girl and Mine states, "The near future ... will reveal to those who advocate equal suffrage that moving pictures, as shown in Your Girl and Mine, will accomplish more for the cause than all those eloquent tongues have done since the movement was started" (MPW, Oct. 3, 1914, p. 764). The article quotes the lead producer of the film Ruth Hannah McCormick, who said that Your Girl and Mine was created because of the potential that suffragists saw in film to speak to the general public. "Realizing that the suffragists, like all other propaganda organizations, spend most of their time talking to themselves in public, I felt like it was necessary to try and originate a means of really reaching the public" (MPW, Oct. 3, 1914, p. 764). McCormick sought to use the technology of film to create alternative media where suffragists could make a film that contained the message that they wanted the public to receive.

McCormick noted that in order to be successful the suffrage cause must be adopted by the enfranchised. For Your Girl and Mine suffragists sought to work with "one of the greatest moving picture men in the country" (MPW, Oct. 3, 1914, p. 764). McCormick claimed "Together we have worked out and produced one of the largest 
photoplays yet presented to the public." Joining forces with mainstream film producers was a technique suffragists used to appeal to widespread audiences. Specifically, when making the film McCormick avoided "just preaching" and aimed to produce a film that "would appeal to every man and woman, regardless of whether they knew anything about the suffrage movement or cared anything about it" (MPW, Oct. 3, 1914, p. 764).

When Your Girl and Mine was released it garnered a lot of publicity in Moving Picture World. The coverage included reviews of the film and its release date, advertisements, as well as articles about the film's production and suffragists making pictures. For instance an article entitled "Your Girl and Mine in Nebraska" notes that local suffragists worked with the production company to make the film "the talk of the year", and added, "That they have succeeded is evident for the attention that they are receiving" (MPW, Feb. 3, 1915, p. 992).

In the meeting minutes of the MSA, there was little commentary on the Montreal screening of Your Girl and Mine. The minutes note that it was shown "under the auspices of the Montreal Suffrage Association", at the Strand and the Casino in Montreal, and that the net profits of $\$ 65$ were given to the Khaki League (MSA, 1913). No details were found in the MSA archives about how they came to book the film Your Girl and Mine; however, a newspaper article (that is missing a publication date, name and headline) states that a "special exhibition" of the film "had been arranged through the kindness of the manager [of the Strand Theatre], Mr. George Nicholas, for the members of the Montreal Suffrage Association and their friends, many of which were present" (Ligue des droits de la femme, 1913). Following a brief description of the film, the article notes that after the morning screening of Your Girl and Mine Professor Carrie Derick, president of 
the MSA, announced that the film would have an extended run at the Casino the following week (Ligue des droits de la femme, 1913).

In an update to the Montreal Council of Women from affiliated societies, the MSA spoke about the screening of the suffrage film Your Girl and Mine. They note that this film was attended by over 4,000 and in addition to its initial screening received a weeklong run. The funds raised by these screenings were donated to the Khaki League as part of the suffragist commitment to the war effort.

The MSA report states that the film "dealt with the unjust laws affecting women and children in the home and in industry" and that "a short address upon Quebec's laws was given at each evening performance" (Montreal Council of Women, 1915). The Montreal exhibition of Your Girl and Mine educated the public about suffragism through both the film itself and the legal speaker who addressed Quebec's laws. Stamp (2000) notes that when lecturers accompanied suffrage films - in the United States it was often suffragists themselves - an additional "voice" was given to the film. By addressing the audience, the speaker brought attention to issues present in the narrative of the film, and at the same time aided the audience by establishing what they could do outside of the theatre. It is through the public speaker element that the Your Girl and Mine Montreal screenings fully demonstrates the advocacy potential of suffrage film exhibition.

In addition to serving an advocacy role, the "movie lecturer" contributed to the educational atmosphere of film (Stamp, 2000). The presence of lecturers was encouraged by exhibitors, who were trying to elevate the status of film as a legitimate, "cultured", and educational form of entertainment (Stamp, 2000). Given the desire of suffragists to 
"clean up" film during the 1910 s, this is certainly something that Canadian suffragists would have encouraged as well.

When the Montreal screening of the suffrage film Your Girl and Mine was discussed by the NCWC the advocacy element of it was not celebrated. Instead, the MSA received attention for their fundraising efforts on behalf of suffragists. The Council of Women of Montreal did not mention how Your Girl and Mine promoted suffragism through film, but simply stated that nearly all women's associations have "been actively engaged in patriotic work, and have responded whole-heartedly to the calls for funds and for workers in the Empire's cause" (NCWC, 1915, p. 92). That the MSA donated the money raised from the Your Girl and Mine screening to the war effort is significant as the original intention of screening the film was to raise money for the suffrage cause. A World Film Incorporation ad for the film featured in the October 13, 1914 edition of Moving Picture World noted that suffrage organizations were selling admission tickets to theatres showing the picture, and that they can be redeemed at 75 per cent face value, with "the balance going to the suffrage cause" (MPW, Oct. 3, 1914, p. 889). In various $M P W$ articles that speak about the exhibition of Your Girl and Mine there is no mention of any American suffrage organization using the money raised from the film's exhibition for anything other than the suffrage cause.

That Canadians used the money raised from Your Girl and Mine screenings in a different way than its original intention is reflective of how the war was influencing the country at the time, as the United States had not yet entered the war in 1914. Canadian suffragists suspended activities to focus on the war effort, cancelling speakers, events and other work. The report of the National Equal Franchise Union states, "A general appeal 
has gone out to all suffragists to do some special war relief work as suffragists....Montreal donated the funds from the production of the Suffrage Movie Your Girl and Mine to patriotic funds" (NCWC, 1915, p. 125). Screening a suffrage film, while still raising money for the war effort, is an example of a creative way that the two were merged.

It was characteristic for Canadian suffrage groups to combine war fundraising with their own political cause. An invitation to a lecture entitled "Women in War Work" by president of CSA Flora MacDonald Denison highlighted that her talk would be illustrated with pictures, and that although admission was free there was a "silver offering for Canadian War Relief" (Denison, "Women in War Work"). In Montreal, funds from a performance of the suffrage play "How the Vote Was Won ${ }^{25 "}$ "were donated to the Red Cross Society. Interestingly the decision to put on a performance of this play came about after the MSA decided to suspend the use of funds on public speakers until after the war was over. The intent of the performance was "to assist as a society in the patriotic enterprises", as all proceeds for the play would be "devoted to patriotic purposes" (MSA, 1914). The MSA's president and other members of the executive committee also spoke on the subjects of "Woman Suffrage" and "Woman and War" in both Montreal and outside the city, such as an event hosted by the Red Cross Teachers Association (Montreal Council of Women, 1915; MSA, 1915).

25 The MSA was not the only Canadian suffrage group to put on a performance of "How the Vote Was Won." As early as 1911 this play was already billed as a "popular comedy" and performed in Toronto under the auspices of the Toronto Suffrage Association (Denison, 1911). 
A news article entitled "Montreal Women and the War: The Montreal Suffrage Association" notes that in 1914-1915, in addition to the screening of Your Girl and Mine, various suffrage activities took place in support of the war effort. These included suffrage booths in the Motor Show and the Made-in-Canada Exhibition, and fundraising efforts such as a suffrage garden party, a theatre exhibition, and speeches (MSA, 1915). The MSA specifically spoke about their desire to combine war efforts and suffragism, as it was believed that it would prove the citizenship abilities of women:

Notwithstanding absorption in the war, the progress made by the suffrage movement is marked. There is a growing recognition of the devotion and selfsacrifice of women and a belief that they have, as, perhaps, never before, demonstrated their worth as citizens of a great empire and their right to equality of opportunity with men in every phase of national life (Montreal Council of Women, 1915, p. 81).

In a 1915 issue of Moving Picture World an article addressing exhibition issues in Toronto states that Canadian suffrage associations were "taking steps to boost the World Film suffrage picture Your Girl and Mine" by trying to arrange a screening of the film where the proceeds would be donated to the Canadian Patriotic Fund. Suffragists did this because "at present very little money is being spent in an effort to get the vote" (MPW, Feb. 20, 1915, p. 1170). The article further states, "It is hoped by making the performance a charitable one that many people not otherwise interested can be persuaded to attend." This highlights that given the war context, Canadian suffragists were not promoting their cause without concurrently doing something to fulfill their patriotic duty. 
Looked at in another way, the suffrage movement was latching onto the popular charity of the time and using the war effort to bring attention to their cause.

A later Moving Picture World article entitled "Toronto Suffragette Boosting Your Girl and Mine" reads, "The Toronto Canada Suffragettes are boosting Your Girl and Mine, and have arranged to give part of the proceeds from the exhibitions to the Canadian Patriotic funds to provide for soldiers families" (MPW, Jan. 2, 1915, p. 1430). No further details are given about if and when this screening took place, as it is not mentioned in later issues of $M P W$ or in any of the suffrage archives consulted for this thesis. Based on these MPW articles it appears as though Your Girl and Mine likely screened in Toronto. However, this is difficult to confirm without any other sources. As noted in chapter two, distribution of Your Girl and Mine was cut because of a disagreement between McCormick and the World Film Corporation (Shore, forthcoming 2013). Without further supporting evidence Toronto might have been one of the locations where distribution fell through. Even if the screening did not take place, the intention was that Toronto suffragists were to use the film Your Girl and Mine in the same way as the MSA: to demonstrate that suffragists were patriotic. (Fig. 8) 


\section{5 - Figures}

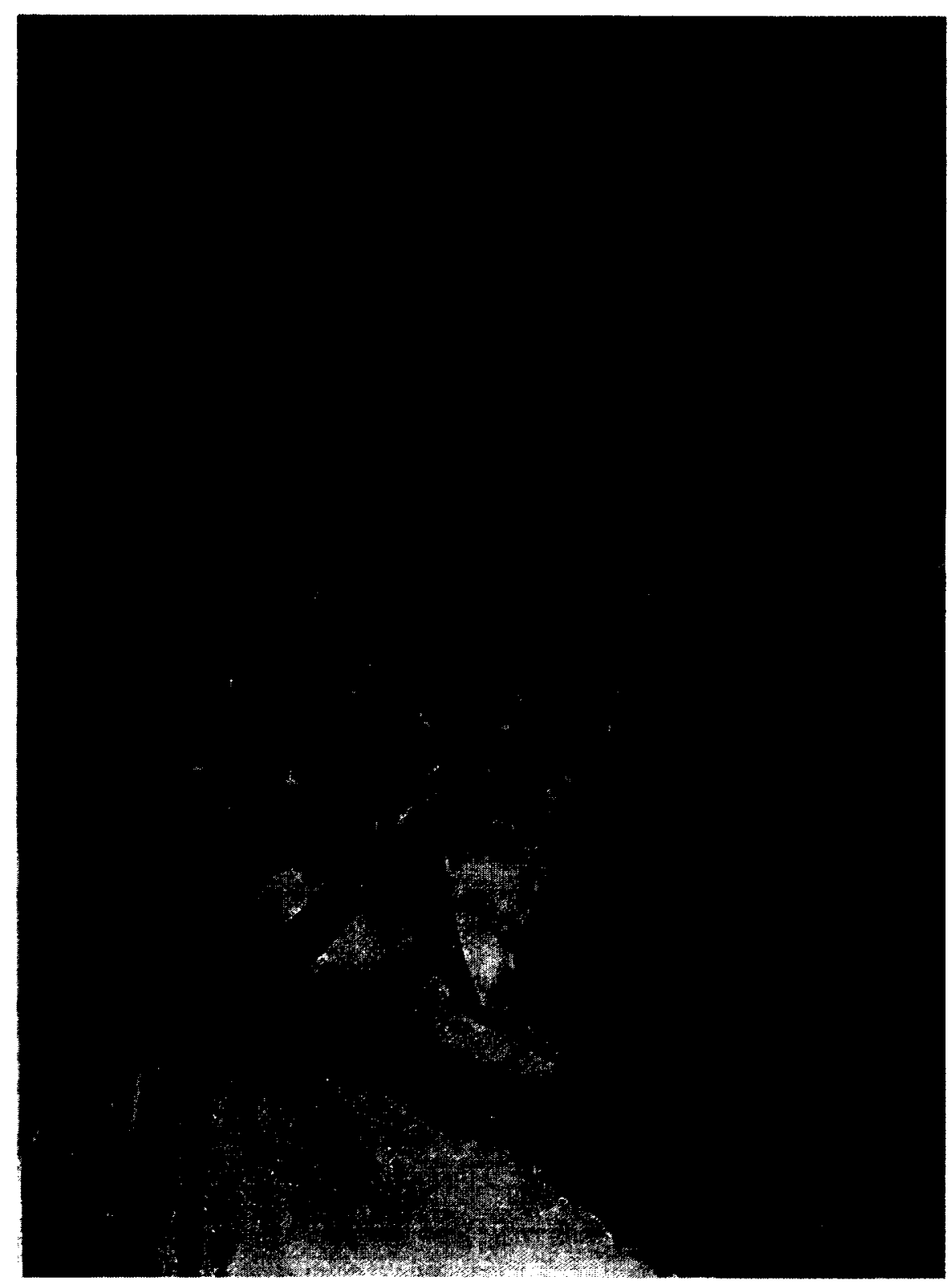

Figure 6: Mrs. Inez Milholland Boissevain. Image from Moving Picture World, July 1914. PDF made available through Media History Digital Library. 


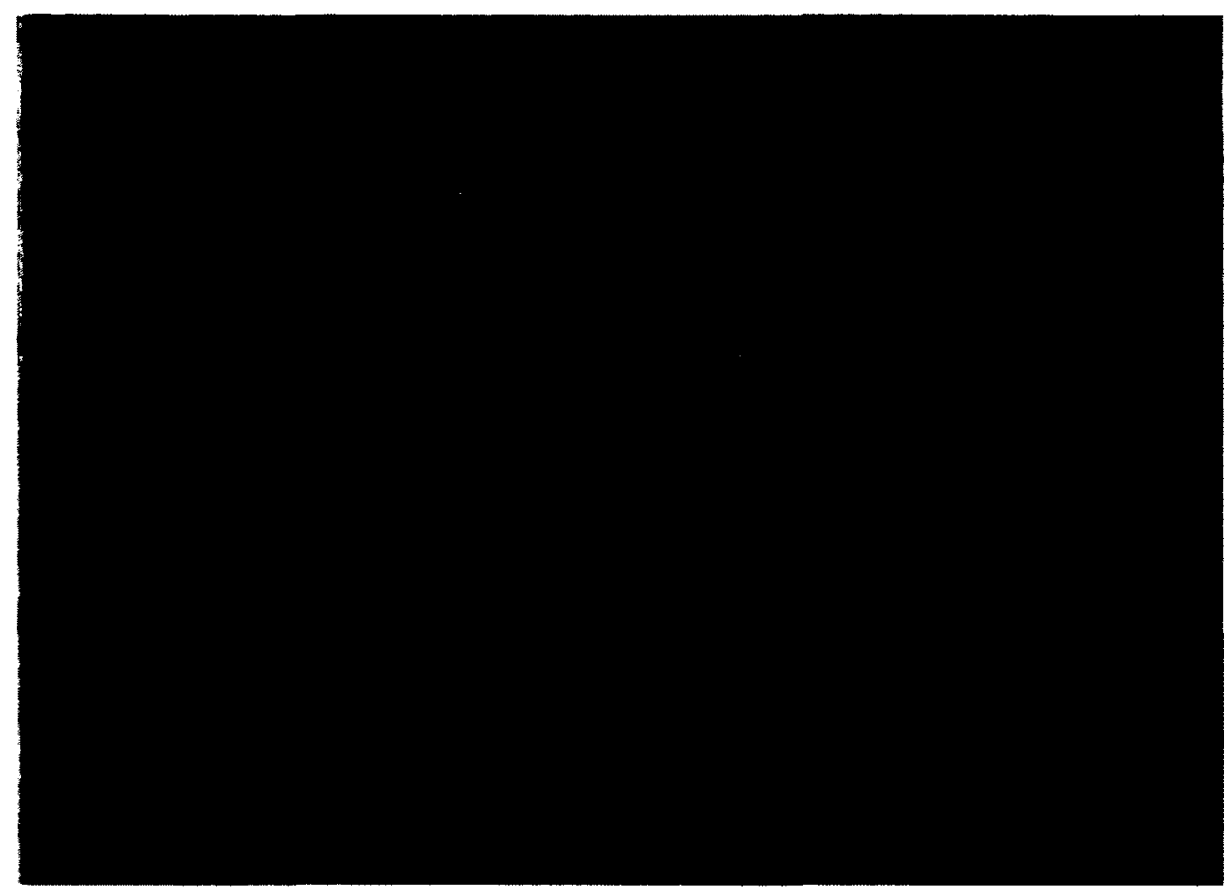

Figure 7: A still featuring a group of prominent suffragists in Votes for Women. Image from Moving Picture World, April - June, 1912. PDF made available through Media History Digital Library. 


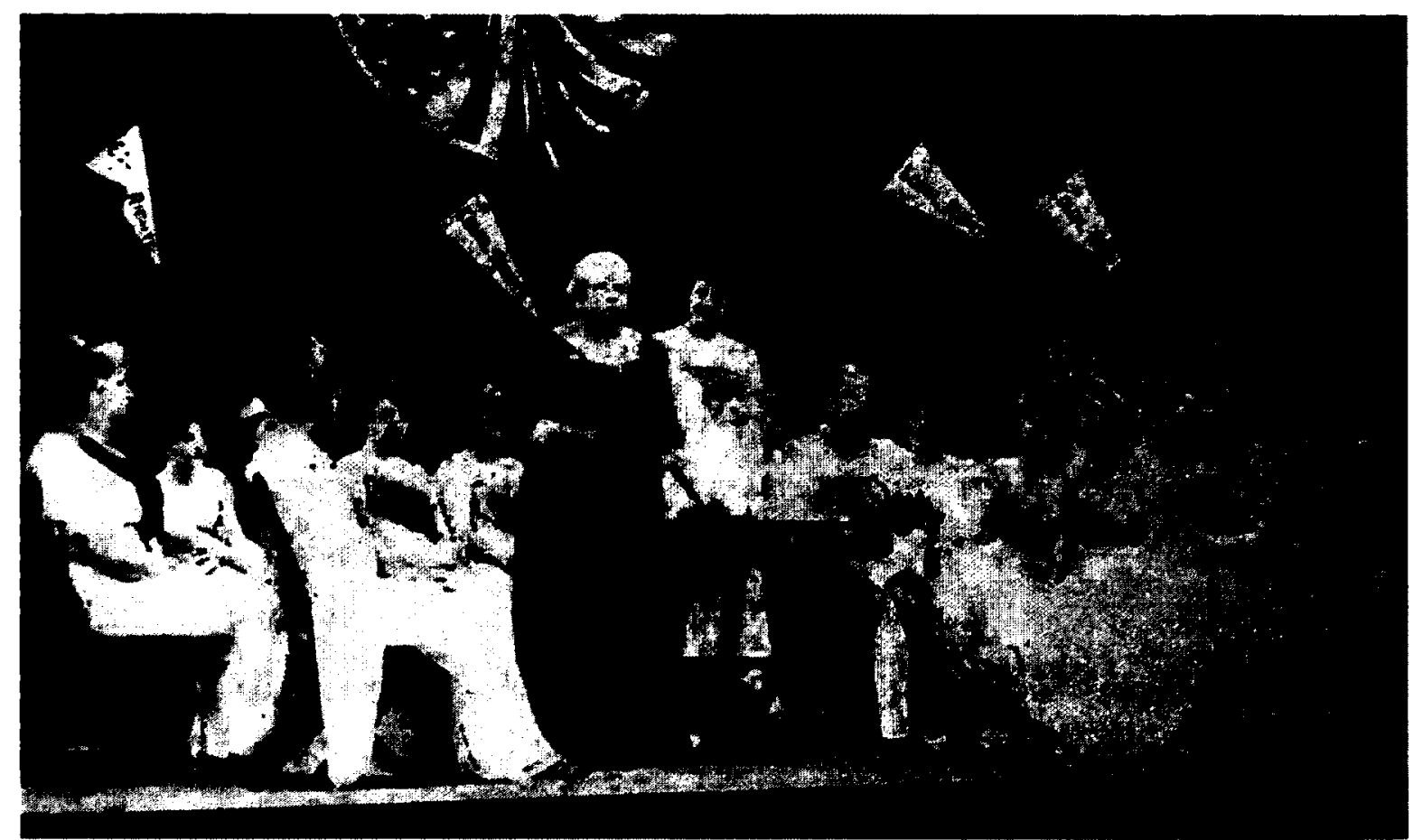

Figure 8: A still from Your Girl and Mine with Dr. Anna Howard Shaw in centre. Image from Moving Picture World, October 3, 1914. PDF made available through Media History Digital Library. 


\section{Conclusion}

\section{A demonstration of citizenship: Regulation and suffrage advocacy}

After women received the federal vote, suffragists continued their advocacy work and expressed the importance of staying involved in public life. In 1919, Augusta StoweGullen, convener of the National Council of Women of Canada's (NCWC) Citizenship Committee, stated that following the legal enfranchisement of women in Canada, women were faced with new problems, and there were other causes in which suffragists should become more actively involved: "With the obtaining in Canada of the franchise of women, an entirely new order of affairs legally and industrially ensues. A new era has dawned, and for women many problems will have to be faced through their recently acquired citizenship" (NCWC, 1919, p. 115). In particular Stowe-Gullen stressed the important role women could play in shaping film regulation in Canada, stating that the Citizenship Committee had been advocating for a board of censorship that included women. In the years after women received the federal vote, women across the country were appointed to provincial censorship boards (Dean 1981; Morris, 1978). Around this time the federal and provincial governments, especially Ontario, increased educational film production. After the establishment of the Ontario Motion Picture Bureau in 1917, by 1919 the Bureau claimed to have "the largest and best equipped studio laboratory in Canada" and their films were being distributed in theatres across the country (Morris, 1978, p. 134).

Suffragists, such as those who belonged to local branches of the NCWC, took a stance on the effects of film, sought to regulate sites of exhibition, and advocated that film be used as an educative medium. While it is presumptuous to conclude that these 
two things - women being appointed to censorship positions and film being used for educational purposes - can solely be attributed to suffragists, they are the two most central film-related issues suffragists talked about and promoted throughout the 1910s.

\section{1 - The suffragist response to film: A focus on regulation}

A search of the literature, as well as film and suffrage archives, did not reveal any Canadian-made suffrage films; however, two suffrage films that travelled throughout the United States were screened in Canada. In the archives consulted for this project, the two films that exhibited in Montreal were verified by multiple sources; the only evidence of the Toronto screening of Your Girl and Mine was found in Moving Picture World, with only a very brief description. Thus, the focus of my study was expanded and I looked at the views of Canadian suffragists about the emerging role of film in Canada between 1909 and 1919. Given what previous historical research revealed about the suffrage movement in Canada and its focus on moral regulation, it is not surprising that women associated with the suffrage movement were actively involved in discussing film and how to regulate it. This doesn't mean suffragists did not see the value of the new medium as entertainment, but primarily they were concerned with the appointment of women censors, and the use of film for educational purposes.

The NCWC local councils spoke at length about the regulation of film. Critical of the negative effects that film could potentially have on audiences, suffragists also recognized its potential. Rather than focusing energies on combating the mere existence of the medium there was an acceptance of it. As Elizabeth Liddell, longtime convener of the Committee on Objectionable Printed Matter, stated in a 1917 report: 
The question of the "Movie" has received considerable attention by all the Local Committees and all maintain that women should be represented on the Board of Censors. The "Movie" has come to stay and we must see that the best features are demanded....We must insist on having pictures that are normal and educative. (NCWC, 1917, p. 89)

Recognizing that film had "come to stay", suffragists stepped into their role as civic housekeepers and worked with film exhibitors and local governments to ensure that film was being used for what they thought were the right purposes. Suffragists saw themselves as central in dealing with the presence of film in Canada.

Women wanted to have an official role in monitoring film exhibition and actively campaigned to do so. This finding is consistent with suffrage literature explored in the first chapter that suggests that women, as well as men, active in the reform movement at the time were seeking to be part of the moral authority of the nation (Bacchi, 1983; Fiamengo, 2006; Iacovetta \& Valverde, 1992). The desire of the NCWC to ensure that films did not contain vulgar material and were educative further supports literature that suggests the Canadian suffrage movement had a commitment to moral regulation (Bacchi, 1983; Kealey, 1979; Valverde, 1991). As Valverde (1991) states, in this period various groups aimed to shape the moral fabric of society, as opposed to simply repressing or censoring. Describing the Canadian reform movement during this period, she writes:

This movement is by no means explained by being labeled as an agency of social control or a Puritan effort at censorship and repression: the movement was held together not only by its attacks on vice but by a common vision of the pure life 
that individuals, families, and the nation would lead in the near future. (Valverde, 1991, p. 32-33)

NCWC members were not trying to stop the production of films. They wanted to be involved in the regulation of film, especially through the role of censors, and to ensure the medium reached its educative potential.

Perhaps what is most interesting about suffragists' rhetoric about the medium, in the context of this study, is the silence from suffragists regarding the potential or promise of film as a means to promote their cause. Especially throughout the mid and late 1910s the educative potential of film was championed, which led to discussions about how NCWC committees might use film. Yet, suffragists gave no indication that they were interested in using film as alternative media to advocate for suffrage. Film was seen as something that could be used for educational purposes, but they did not discuss how it could be used for advocacy. Reports from the Canadian Suffrage Association (CSA) found in the NCWC yearbooks often talked about advocacy endeavors taken by the group, which tended to be in more traditional forms, such as lectures, plays, and circulating literature. While local women's councils had relationships with theatre owners and found ways to influence programming - such as campaigning to have more children friendly movies shown on Saturday afternoons - they either did not try, or were not successful, in efforts to have American suffrage films exhibited in local theatres for an extended period of time.

While suffragists were not without concerns regarding film, they did not subscribe to the belief that it was inherently evil. Taking their role as maternal feminists seriously, they aimed to oversee the semipublic space of the theatre, as well as the content of films. 
This fits within the general view of the time regarding women's desire to clean up and oversee public spaces, especially within urban centres. The concern about content stemmed from a concern for its assumed effects on audience behaviour. Appropriately, given the general moral reform climate in North America, suffragists also spoke about the need for wholesome and educational films.

\section{2 - The 'success' of suffrage film screenings}

Recent studies, such as those offered by Amy Shore in her forthcoming 2013 book The Silver Screen, note the importance of suffrage films in American history. These films, which I defined as a form of alternative media, had an influence on both the film industry and the women's movement. Given the strong links between the Canadian and American suffrage movements, and Canada's continued exhibition of American films, one might expect that the influence of suffrage film would be seen in Canada.

Considering this, it is important to assess if the exhibition of these films outside of the United States were successful in terms of spreading the suffrage message through the medium of film.

Montreal exhibited two American suffrage films, and Toronto exhibited one. There is a possibility that there were other screenings outside these cities, but based on the findings of this study, the films made by suffragists in the United States were only seen by a limited number of Canadian men and women. The small-scale exhibition of Votes for Women and Your Girl and Mine brought the cinematic suffrage message to Montreal and Toronto screens for a short time. The products of American suffrage filmmakers that had the potential to expose Canadian audiences to the suffragist message 
through the popular medium of the period is quite restricted: 4,000 people were reported to see Your Girl and Mine in Montreal, and my research found no numbers for the planned Toronto screening, or confirmation that it even took place. While it is possible (though somewhat unlikely) that suffrage films were screened in other Canadian cities, if Montreal and Toronto turn out to be the only places where American suffrage films were exhibited, based on the number of individuals exposed to the films, it would be difficult to consider the Canadian use of suffrage film a success.

Canadian suffragists did not speak about the potential of film as alternative media or using film for advocacy purposes. Yet, the Canadian screenings of Your Girl and Mine offers an example of how suffrage films were used for advocacy, even if the suffrage organizations of the period remained mostly silent on it. Although Your Girl and Mine was screened in Montreal in conjunction with a speaker who talked about Quebec laws, that the film raised money for the war effort received much more attention in the MSA and NCWC reports, as well as newspaper articles. When the film was exhibited in 1914 Canada had just entered the First World War and suffragists across the country sought to contribute. Although it may seem that the suffrage cause was being overshadowed by the war, suffragists took advantage of the situation.

The proceeds raised from the exhibition of Your Girl and Mine were donated to the war effort, and this approach was a central way that suffragists demonstrated their patriotism. Canadian suffragists were confident that their efforts during the war proved their ability to be model citizens deserving of the vote. Speaking to the NCWC in 1918, convener of the Citizenship Committee Augusta Stowe-Gullen, stated: 
Even in a world of war it is impossible to suppress the joy that suffragists naturally experience at the phenomenal advance in Canada (and indeed the world) during this past year. The efficient service give this cause by men and women reformers has at last kindled a flame which is enveloping a world, and an epoch in human history has begun in which women are to take their natural and rightly appointed place in human relationships and human affairs....No thinking person doubts the complete success of suffrage for Canadian women. Our nation has discovered how much it needs the co-operation and actual work of women in war, as well as in peace; and it is safe to predict that never again will women be relegated to the unequal economic, legal and political position that women occupied before the war. (NCWC, 1918, p. 53-54)

Although Augusta Stowe-Gullen makes claims about the success of suffrage for "Canadian women" it is important to consider that this was not inclusionary of all women. Questions of race, class and disability were still important considerations in who had access to the vote, as well as which women were actively involved in public life.

The findings in this study, regarding the exhibition of the suffrage film Your Girl and Mine, supports Moore's (2008) thesis about filmgoing as an act of citizenship. Moore argues that those who were disenfranchised, mostly women and foreign-born audiences, were targeted as a mass audience and encouraged to attend movies as a display of patriotism during the First World War. At a time where there was "little to no film production in Ontario", propaganda or patriotic state-sponsored films were not screened in theatres, but instead "the network of showmanship, regulation, and promotion that had just taken shape as the war began allowed moviegoing easily to become an act of 
citizenship as long as the fighting lasted" (p. 200). Moore argues that women and immigrants were participating in the act of filmgoing, and that this - which involved the gathering of a mass public - was a demonstration how the new mass culture effectively enfranchised those without formal citizenship.

More concretely portions of box office proceeds were often given to the War Relief Fund, similar to how suffragists donated money from the Your Girl and Mine screenings. This allowed audiences to "act patriotically" and participate in fundraising efforts in a "cultural space developed specifically to include [children, young women, and foreign-born families]", who tended to be the "typical audience for movie shows" (Moore, 2008, p. 214). Although Moore suggests that Canadians demonstrated their citizenship through moviegoing - regardless of the films they actually watched in the theatre - the screenings of a suffrage film to raise money for the war offers an interesting account of the overt efforts of suffragists to use film for patriotic purposes, while simultaneously spreading their own political message.

Canadian women won the vote earlier than their American counterparts. Most Canadian women received provincial enfranchisement during the 1910s and the federal vote in 1917. American women were not fully enfranchised until the Nineteenth Amendment to the United States Constitution was passed in $1920^{26}$. Despite a different timeline of success, the co-operation and unity of American and Canadian suffragists was important to the overall momentum of the North American movement. This sentiment

${ }^{26}$ Similar to receiving the provincial vote in Canada, some American women received voting rights at the state level prior to this. 
was expressed by Canadian suffragist Flora MacDonald Denison in her column that appeared in the Toronto Sunday World on May 8, 1910:

It is impossible to separate the work of American and Canadian women in their fight for the ballot. We are just as interested in their progress as we are in our own, for in the great conventions we have learned that this is an international movement and a gain in one country means a gain in every country.

Committed men and women living in both the United States and Canada worked to ensure suffrage laws were passed in the first part of the twentieth century. By utilizing different forms of alternative media, such as suffrage film, suffragists sought to expose the general public to their message. Given the context of the First World War, Canadian suffragists found a way to use American produced suffrage films to demonstrate their patriotism, which was central in their overall advocacy approach.

\section{3 - Suggestion for further research}

It is disappointing, though not surprising, that more is not known about suffragists' role within early Canadian film history. As with much historical research based on archival material, the absence of particular information and documents leaves many questions unanswered. Further explorations of Canadian film and suffragism could focus on several areas where information is available. A nation wide study, which looks at suffrage archives from all areas of Canada, would clarify if there were any other cities where American suffrage films were screened. Comprehensive content analysis of newspapers from this period might offer more information and details about suffrage film screenings. 
Another area of research is popular or mainstream studio productions that had suffrage characters or stories. Although these films often portrayed suffragists in a very stereotypical and negative way, as noted in chapter two, such films were very popular in the United States. It would be interesting to see if these films made their way to Canada, and to explore how Canadian audiences received them. Another project could study newsreels that screened before films in theatres to see if they contained any Canadian suffrage footage. Morris (1992) notes that because of demand, by 1914 Canadians were watching newsreels that were Canadian produced and focused on events that were significant in the country. Perhaps this is one context in which Canadian suffragists were seen on screen. In relation to regulation, one could further study the NCWC's campaign to get women on provincial censor boards, and study the response from the public as well as the government bodies who appointed them.

This thesis has laid groundwork to further study Canadian suffragists' perception of film in the 1910s, and to explore how they used the medium for advocacy purposes. Based on archival research I concluded that no suffrage films were produced in Canada, and that exhibition of American produced suffrage films was limited. Consistent with how maternal feminism was enacted in the culture of the North American reform movement, suffragists focused on regulating the sites of exhibition and content of films, while working to establish women censors and the screening of educational films. Though vocal about these issues, they were generally silent on using film for advocacy. Co-productions between Canadian suffragists and production companies did not occur as they did with their American counterparts, but this is likely reflective of the Canadian film industry at the time and not simply a matter of suffragists overlooking the medium. 
Suffragists saw the value and potential of film, just not the feasibility of producing advocacy films. When they did screen Your Girl and Mine, Canadians used the American suffrage film as part of their overall strategy to not simply expose audiences to the suffrage message, but to convince audiences why women were deserving of the vote. How Canadian suffragists responded to film, both by regulating it and screening an American suffrage film to raise money for the war effort, was a demonstration of their desired citizenship. 


\section{Works Cited}

\section{Primary sources}

Colonial Film Co. (1912, April-June). Suffragette Pageant and Tableau [advertisement] (p. 1391). In Moving Picture World Vol. 15. New York: The World Photographic Publishing Co. Retrieved from http://mediahistoryproject.org/ (Media History Digital Library).

Gaumont (1913, July 5). 25 Dollars Buys the 1913 Derby [advertisement] (p. 239). In Moving Picture World Vol. 17. New York: The World Photographic Publishing Co. Retrieved from http://mediahistoryproject.org/ (Media History Digital Library).

Ligue des droits de la femme (1913). Montreal women and the war: The Montreal Suffrage Association. No date or publication information. In Scrapbook - 1913. Available from Archives of Montreal (Research file BM14).

--- (1913a, April 25). Suffragists to be peaceful: Sweet reasonableness in methods to characterize newly-formed local association: Prof. Derick president: Sketched movement during 25 years - Interesting speeches at inaugural meeting last night. The Gazette. In Scrapbook - 1913. Available from Archives of Montreal (Research file BM14).

MacDonald Denison, F. (1911, March 31). Official Programme: How the Vote Was Won. Available from Thomas Fisher Rare Book Library (Woman's Suffrage Manuscript Collections 51, Box 2).

-- (1910, May 8). Under the pines: What women are doing for the advancement of 
civilization - suffrage news. Toronto World. In Scrapbooks [microfilm]. Available from Thomas Fisher Rare Book Library (Woman's Suffrage Manuscript Collections 51, Item 7).

Montreal Council of Women (1915). 21st Annual Report: May 18, 1915 [microfilm]. Available from Library and Archives Canada (Research file MG 28 I 164).

Montreal Suffrage Association (1913/1914/1915/1916). Minute Book: Meetings 1913, 1914, 1915, 1916 (N. 41). Available from City of Montreal Archives (Research file BM 101, D2).

Moving Picture World (1912, January - March). Motion picture exhibitors league (p. 569). Vol. 11. New York: The World Photographic Publishing Co. Retrieved from http://mediahistoryproject.org/ (Media History Digital Library).

--- (1912, April - June). Degrading the pictures (p. 1105). Vol. 12. New York: The World Photographic Publishing Co. Retrieved from http://mediahistoryproject.org/ (Media History Digital Library).

--- (1912, April - June). Anna Shaw and Jane Addams in pictures: Leading suffragettes of the United States assemble at the Reliance Studio to appear before camera (p. 617). Vol. 12. New York: The World Photographic Publishing Co. Retrieved from http://mediahistoryproject.org/ (Media History Digital Library).

-- (1912, April - June). Votes for Women: A serious presentation of the suffrage propaganda, in two reels, by the Reliance Company - with notable cast" [film review] (p. 811). Vol. 12. New York. Retrieved from http://mediahistoryproject.org/ (Media History Digital Library). 
--- (1913, July). What 80 Million Women Want ---? (p. 619). Vol. 17. New York.

Retrieved from http://mediahistoryproject.org/ (Media History Digital Library).

--- (1914, July). Mrs. Boisevain's talks on pictures (by Florence Margolies) (p. 947). Vol,

21. New York. Retrieved from http://mediahistoryproject.org/ (Media History Digital Library).

--- (1914, Oct. 3) Major Funkhouser Rouses Ire of Leading Suffragists (p. 621). Vol. 22, No. 1. New York. Retrieved from http://mediahistoryproject.org/ (Media History Digital Library).

--- $(1914$, Oct. 3) Your Girl and Mine: A powerful photomelodrama in eight reels, by Selig, specially produced for Mrs. Medill McCormick and the National American Woman Suffrage Association. Reviewed by James S. McQuade. (p. 764). Vol. 22. No. 1. New York. Retrieved from http://mediahistoryproject.org/ (Media History Digital Library).

--- (1915, Jan. 2). Your Girl and Mine in Nebraska. (p. 992). Vol. 23, No. 1 New York. Retrieved from http://mediahistoryproject.org/ (Media History Digital Library).

--- (1915, Jan. 2). Organization Felt: Suffrage Pictures in Canada. By David K. Billings. (p. 1170). Vol. 22, No. 1. New York. Retrieved from http://mediahistoryproject.org/ (Media History Digital Library).

--- (1915, Jan. 2). Toronto suffragette boosting "Your Girl and Mine" (p. 1430). Vol. 23, No. 1. New York. Retrieved from http://mediahistoryproject.org/ (Media History Digital Library).

National Council of Women of Canada (NCWC). (1903). Official documents Vol. 12 
[microfilm]. Available from Library and Archives Canada (Research file MG 28, I 25).

--- (1909). The Year Book: Women Workers of Canada. Toronto: Parker \& Sons Printers. Available from Library and Archives Canada (Research file MG 28, I 25).

-- (1911). The Year Book: Women Workers of Canada. Toronto: Parker \& Sons Printers. Available from Library and Archives Canada (Research file MG 28, I 25).

--- (1912). Official documents. Vol. 21 [microfilm]. Available from Library and Archives Canada (Research file MG 28, I 25).

--- (1912a). The Year Book: Women Workers of Canada. Toronto: G. Parker \& Sons Printers. Available from Library and Archives Canada (Research file MG 28, I 25).

--- (1913). The Year Book: Women Workers of Canada. Toronto: Parker Bros., Limited Printers. Available from Library and Archives Canada (Research file MG 28, I 25).

--- (1914). Hand-book of the National Council of Women of Canada [booklet]. Available from Library and Archives Canada (Research file MG 28, I 25).

--- (1914a). Official documents [microfilm]. Vol. 23. Available from Library and Archives Canada (Research file MG 28, I 25).

--- (1915). Official documents [microfilm]. Vol. 24. Available from Library and Archives Canada (Research file MG 28, I 25).

--- (1915a). The Year Book of the National Council of Women of Canada. Toronto: National Council of Women of Canada. Available from Library and Archives Canada (Research file MG 28, I 25). 
--- (1917). The Year Book of the National Council of Women of Canada. Toronto: Bryant Press. Available from Library and Archives Canada (Research file MG 28, I 25 ). --- (1918). The Year Book of the National Council of Women of Canada. Toronto: Bryant Press. Available from Library and Archives Canada (Research file MG 28, I 25).

--- (1919). The Year Book of the National Council of Women of Canada. Toronto: Murray Printing Co., Limited Toronto. Available from Library and Archives Canada (Research file MG 28, I 25).

Pathé (1914). Suffragette Reels: April 27th [advertisement] (p. 177). In Moving Picture World (1914, April 4). Vol. 20. New York: The World Photographic Publishing Co. Retrieved from http://mediahistoryproject.org/ (Media History Digital Library).

Reliance Studios (1912, April - June). Votes for Women [advertisement] (p. 1094). In Moving Picture World (1912, April - June). Vol. 12. New York: The World Photographic Publishing Co. Retrieved from http://mediahistoryproject.org/ (Media History Digital Library).

Ridley, H. (n.d.) A synopsis of woman suffrage in Canada [microfilm pamphlet]. Available from Wilfrid Laurier University Archives (Emily Stowe and Augusta Stowe-Gullen Collection).

Stowe-Gullen, A. (1911, March 22). Voices not votes for the ladies. Star. In Scrapbooks [microfilm]. Available from Wilfrid Laurier University Archives (Emily Stowe and Augusta Stowe-Gullen Collection).

Unique Films Company (1913, July 5). 80 Million Women Want ---? [advertisement] (p. 
763). In Moving Picture World Vol. 17. New York: The World Photographic Publishing Co. Retrieved from http://mediahistoryproject.org/ (Media History Digital Library).

Unknown author (1912, June 22). Cecil Spooner in her own color and costume confusion, and suffragettes in pictures. Montreal Star. Retrieved from Library and Archives Canada.

World Film Corporation (1914). Announcement: Special Attractions Department [advertisement] (p. 1887). In Moving Picture World Vol. 22, No. 1. New York. Retrieved from http://mediahistoryproject.org/ (Media History Digital Library).

--- (1914) Your Girl and Mine [advertisement] (p. 889) In Moving Picture World Vol. 22, No. 1. New York. Retrieved from http://mediahistoryproject.org/ (Media History Digital Library). 


\section{Secondary Sources}

Abel, R. (1995) The Perils of Pathé or the Americanization of Early American Cinema. Cinema and the invention of modern life. In L. Charney \& V. R. Schwartz (Eds). University of California Press. Berkeley and Los Angeles, California. P. 183-223. Bacchi, C. L (1983). Liberation deferred? The ideas of the English-Canadian suffragists, 1877-1918. Toronto: University of Toronto Press.

Bowser, E. (1990). History of the American cinema 2: The transformation of cinema 1907-1915. C. Harpole (General Editor). New York: Charles Scribner’s Sons.

Brown, C.R. \& Cook, R. (1974). Canada: 1896-1921: A Nation transformed. Toronto: McClelland and Stewart Limited.

Burt, S., Code, L. \& Dorney, L. (1988). Changing patterns: Women in Canada. Toronto: McClelland and Stewart.

Callahan, V. (2010). Reclaiming the archives: Feminism and film history. Detroit: Wayne State University Press, 309-328.

Cleverdon, C. L. (1974). The woman suffrage movement in Canada: The start of liberation. Toronto: University of Toronto Press.

Cook, R. (1974). Introduction. In C.L. Cleverdon's The start of liberation: The woman suffrage movement in Canada. Toronto: University of Toronto Press.

Coyer, K. Dowmunt, T. \& Fountain, A. (2007). The alternative media handbook. London and New York: Routledge.

Dean, M. (1981). Censored! Only in Canada. Toronto: Vertigo Press.

Downey, J. \& Fenton, N. (2003) New media, counter publicity and the public sphere. New media \& society. 5; 185 . Published by Sage. p. 185-201. 
Downing, J. H. with Vilarreal Ford, T., Gil, G. \& Stein, L. (2001). Radical media: Rebellious communication and social movement. Thousand Oaks, London, New Delhi: Sage Publications Inc.

Errington, J. (1988). Pioneers and suffragists. In S. Burt, L. Code and L. Dorney. Changing patterns: Women in Canada. Toronto: McClelland and Stewart.

Ewen, E. (1980). City Lights: Immigrant women and the rise of the movies. Signs, 5 (3) Supplement, p. 45-65

Fiamengo, J. (2006). Rediscovering our foremothers again: Racial ideas of Canada's early feminists, 1885-1945. In M. Gleason \& A. Perry's Rethinking Canada fifth edition: The promise of women's history. Oxford: Oxford University Press Canada.

Fraser, N. (1989). What's critical about critical theory? The case of Habermas and gender. In Unruly practices: Power, discourse, and gender in contemporary social theory. Minneapolis: University of Minnesota Press.

Friedberg, A. (1993). Window shopping: Cinema and the postmodern. Berkeley and Los Angeles: University of California Press.

Gittings, C. E. (2002). Canadian national cinema: Ideology, difference and representation. London and New York: Routledge

Gorham, D. (1979). Flora MacDonald Denison: Canadian feminist. In L. Kealey (Ed.) A not unreasonable claim: Women and reform in Canada, 1880s-1920s (p. 47-70). Toronto: The Women's Press.

Greenberg, J. and Gilberds, H. (2011). Alternative media. In W. Straw et al.'s (Eds.) 
Intersections of media and communications: Concepts and critical frameworks. (p. 197-216). Toronto: Emond Montgomery Press.

Hansen, M. (1983). Early silent cinema: Whose public sphere? New German Critique 29 (Spring-Summer), 147-184.

Iacovetta, F. \& Valverde, M. (1992). Gender conflicts: New essays in women's history. Toronto: University of Toronto Press.

Kealey, L. (1979). A not unreasonable claim: Women and reform in Canada, 1880s1920s. Toronto: The Women's Press.

Keil, C. \& Singer, B. (2009). American cinema of the 1910s: Themes and variations. New Brunswick, New Jersey, and London: Rutgers University Press.

Krook, M. L. \& Childs, S. Women, gender, and politics: A reader. Oxford \& New York: Oxford University Press.

Lang, M. (1999). Women who made the news: Female journalists in Canada, 1880-1945. Montreal \& Kingston: McGill-Queen's University Press.

Lavigne, M., Pinard, Y. \& Stoddart, J. (1979). The Fédération Nationale Saint-JeanBaptiste and the Women's Movement in Quebec. In L. Kealey (Ed.) A not unreasonable claim: Women and reform in Canada, 1880s-1920s (p. 71-88). Toronto: The Women's Press.

Mackintosh, P. G. (2005). Scrutiny in the modern city: The domestic public and the Toronto Local Council of Women at the turn of the twentieth century. Gender, Place \& Culture 12 (1), 29-48.

Maltby, R. (2011). New cinema histories. In R. Maltby, D. Biltereyst and P. Meers' 
(Eds.) Explorations in new cinema history: approaches and case studies (p. 3-40).

West Sussex: Wiley-Blackwell.

McClung, N. L. (1972). In times like these. Toronto and Buffalo: University of Toronto Press.

Meehan, J. (1995). Feminists read Habermas: Gendering the subject of discourse. New York: Routledge.

Melnyk, G. (2004). One hundred years of Canadian cinema. Toronto: University of Toronto Press.

Mitchinson, W. (1979). The WCTU: 'For God, home and native land': A study in nineteenth-century feminism. In L. Kealey (Ed.) A not unreasonable claim: Women and reform in Canada, 1880s-1920s (p. 15-45). Toronto: The Women's Press.

Moore, P. S. (2008). Now playing: Early moviegoing and the regulation of fun. New York: New York Press.

--- (2008a). Nationalist film-going without Canadian-made films? In R. Abel, G. Bertellini \& R. King (Eds.) Early Cinema and the "National" (p. 155-163). New Barnet John Libbey Publishing Ltd.

--- (2011). The social biograph: Newspapers as archives of the regional mass market for movies. In R. Maltby, D. Biltereyst and P. Meers' (Eds.) Explorations in new cinema history: approaches and case studies (p. 263-279). West Sussex: WileyBlackwell.

Morris, P. (1992). Embattled shadows: A history of Canadian cinema 1895-1939. Montreal \& Kingston: McGill-Queen's University Press. 
Norden, M. F. (1986) A good travesty upon the suffragette movement: Women's suffrage films as genre. JPF\&T-Journal of popular film and television. Winter: 13.4 .

Pedersen, D. (1996). Providing a woman's conscience: The YWCA, female evangelicalism, and the girl in the city, 1870-1930. In W. Mitchinson, P. Bourne, A. Prentice, G. Cuthbert Brandt, B. Light \& N. Black (Eds.) Canadian women: A reader (p. 194-233). Toronto: Harcourt Brace \& Canada Company Ltd.

Pendakur, M. (1990). Canadian dreams and American control: The political economy of the Canadian film industry. Detroit: Wayne University State Press.

Prentice, A., Bourne, P., Cuthbert Brandt, G., Light, B. Mitchinson, W., Black, N. (2004) Canadian Women: A history second edition. Scarborough: Nelson.

Roberts, W. (1979). Rocking the cradle for the world: The new woman and maternal feminism, Toronto 1877-1914. In L. Kealey (Ed.) A not unreasonable claim: Women and reform in Canada, 1880s-1920s (p. 15-45). Toronto: The Women's Press.

Rosen, M. (1973). Popcorn Venus. New York: Avon Books. Ryan, M. P. (1990). Women in public: Between banners and ballots, 1825-1880. Baltimore and London: The John Hopkins University Press.

Scraton, S. \& Watson, B. (1998). Gendered cities: Women and public leisure space in the 'postmodern city.' Leisure Studies 17, 123-137.

Shore, A. (2003). Suffrage and the silver screen. PhD Dissertation, New York University. -- (2010). Making more than a spectacle of themselves: Creating the militant 
suffragette in Votes for Women. In V. Callahan (Ed.) Reclaiming the archives:

Feminism and film history (p. 309-328). Detroit: Wayne State University Press.

--- (forthcoming 2013). Suffrage and the silver screen. Peter Lang.

Sloan, K. (1981). Sexual warfare in the silent cinema: Comedies and melodrams of woman suffragism. American Quarterly Vol. 33, No. 4. Autumn, 1981, p. 412436.

-- (1988). The loud silents: Origins of the social problem film. Urbana: University of Illinois Press.

Stamp, S. (1998). Eighty million women want-? Women's suffrage, female viewers, and the body politic. Quarterly Review of Film and Video 16 (1), 1-22.

--- (2000). Movie-struck girls: Women and motion picture culture after the nickelodeon. Princeton: Princeton University Press.

--- (1995) Toronto's "Girl workers." The female body and industrial efficiency in Her Own Fault. Cinéma 6 (1), 81-99.

Strange, C. (1995). Toronto's girl problem: The perils and pleasures of the city, 1880-1930. Toronto: Toronto University Press.

Thieme, K. (2006). Uptake and genre: The Canadians reception of suffrage militancy. Women's studies international forum 29 (2006) 279-288.

Thompson, K. \& Bordwell, D. (2003) Film history: An introduction, second edition. New York: McGraw Hill.

Tunstell, D. (Director). (1958). Women on the march: The struggle for equal rights [Film]. National Film Board of Canada.

Valverde, M. (1991). The age light, soap, and water: Moral reform in English Canada, 
1885-1925. Toronto: McClelland \& Stewart Inc.

-- (1992). When the mother of the race is free: Race, reproduction, and sexuality in first-wave feminism. In F. Iacovetta \& Valverde, M. (Eds.) Gender conflicts: New essays in women's history. (p. 3-26). Toronto: University of Toronto Press.

Waltz, M. (2005). Alternative and activist media. Edinburgh: Edinburgh University Press.

Winton E. \& Klein, N. (2010). Foreword: Putting ideas into the world: A conversation with Naomi Klein about starting conversations with film T. Waugh, M. B. Baker \& E. Winton's Challenge for change: Activist documentary at the National Film Board of Canada. Montreal \& Kingston: McGill-Queen's University Press. 